\title{
CONSTRUÇÃO DE SISTEMAS BACTERIANOS PARA A DETECÇÃO DE METAIS PESADOS EM AMOSTRAS AMBIENTAIS
}

Tese apresentada ao Programa de Pós-Graduação Interunidades em Biotecnologia USP/Instituto Butantan/IPT, para obtenção do Título de Doutor em Biotecnologia. 


\section{CONSTRUÇÃO DE SISTEMAS BACTERIANOS PARA A DETECÇÃO DE METAIS PESADOS EM AMOSTRAS AMBIENTAIS}

Tese apresentada ao Programa de Pós-Graduação Interunidades em Biotecnologia USP/Instituto Butantan/IPT, para obtenção do Título de Doutor em Biotecnologia.

Área de concentração: Biotecnologia

Orientadora: Profa. Dra. Elisabete José Vicente

Versão original 
DADOS DE CATALOGAÇÃO NA PUBLICAÇÃO (CIP)

Serviço de Biblioteca e Informação Biomédica do

Instituto de Ciências Biomédicas da Universidade de São Paulo

reprodução não autorizada pelo autor

Quadros, Oeber de Freitas.

Construção de sistemas bacterianos para a detecção de metais pesados em amostras ambientais / Oeber de Freitas Quadros. -- São Paulo, 2011.

Orientador: Elisabete José Vicente.

Tese (Doutorado) - Universidade de São Paulo. Instituto de Ciências Biomédicas. Programa de Pós-Graduação Interunidades em Biotecnologia USP/IPT/Instituto Butantan. Área de concentração: Biotecnologia. Linha de pesquisa: Genética molecular e de microrganismos.

Versão do título para o inglês: Construction of bacterial systems of the detection of heavy metals in environmental samples.

Descritores: 1. Bioluminescência 2. Meio ambiente 3. Biotecnologia 4. Regulação gênica 5. Metais pesados 6. Bactérias I. Vicente, Elisabete José II. Universidade de Sâo Paulo. Instituto de Ciências Biomédicas. Programa de Pós-Graduação Interunidades em Biotecnologia USP/IPT/Instituto Butantan III. Título. 


\section{UNIVERSIDADE DE SÃO PAULO \\ Programa de Pós-Graduação Interunidades em Biotecnologia}

Universidade de São Paulo, Instituto Butantan, Instituto de Pesquisas Tecnológicas

Candidato:

Título da Tese:

Orientadora:

A Comissão Julgadora dos trabalhos de Defesa da Tese de Doutorado, em sessão pública realizada a

Oeber de Freitas Quadros.

Construção de sistemas bacterianos para a detecção de metais pesados em amostras ambientais.

Profa. Dra. Elisabete José Vicente.

\section{( ) Aprovado $\quad$ ( ) Reprovado}

Examinador(a): $\quad$ Assinatura:

Nome:

Instituição:

Examinador(a): $\quad$ Assinatura:

Nome:

Instituição:

Examinador(a): $\quad$ Assinatura:

Nome:

Instituição:

Examinador(a): $\quad$ Assinatura:

Nome:

Instituição:

Presidente: $\quad$ Assinatura: 


\section{CERTIFICADO DE ISENÇÃO}

Certificamos que o Protocolo CEP-ICB No 446/11 referente ao projeto intitulado: "Construção de sistemas bacterianos para a detecção de metais pesados em amostras ambientais" sob a responsabilidade de Oeber de Freitas Quadros, foi analisado na presente data pela CEUA - COMISSÃO DE ÉTICA NO USO DE ANIMAIS e pela CEPSH- COMISSÃO DE ÉTICA EM PESQUISA COM SERES HUMANOS, tendo sido deliberado que o referido projeto não envolve manipulação animal ou humana que justifique uma aprovação quanto aos princípios éticos exigidos por ambas as Comissões.

São Paulo, 23 de março de 2011.

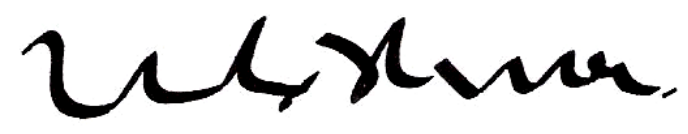

PROF. DR. WOTHAN TAVARES DE LIMA Coordenador da CEUA - ICB/USP

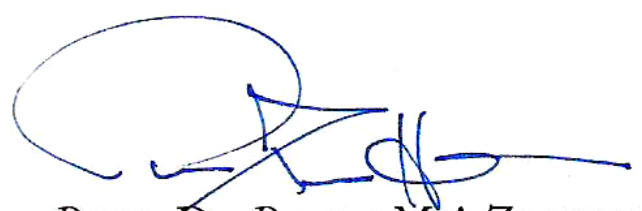

PROF. DR. PaOlo M.A ZanotTo Coordenador da CEPsh - ICB/USP 
À minha esposa Cristiele pelos anos de amor, companheirismo, dedicação, paciência, estímulo e ajuda.

Ao meu filho Cauê, que na sua inocência de criança, tem me ajudado a entender que as coisas mais simples da vida são aquelas que mais valorizamos e jamais esquecemos. 


\section{AGRADECIMENTOS}

A Deus, por dar-me vida e saúde para conquistar mais uma vitória. A Ele seja dada toda honra e glória!

À professora e orientadora $\operatorname{Dr}^{\mathrm{a}}$. Elisabete José Vicente, pela experiência transmitida, pelo incentivo nas horas difíceis, amizade, confiança, encorajamento, paciência e oportunidade.

À Prof ${ }^{\mathrm{a}}$. Dr ${ }^{\mathrm{a}}$. Ana Clara Guerrini Schenberg, presidente do Programa de Pós-Graduação Interunidades em Biotecnologia USP/Instituto Butantan/IPT, por todo apoio dedicado.

À Companhia Vale do Rio Doce (CVRD), pelo auxílio financeiro, sem o qual a realização deste trabalho não teria sido possível.

Aos meus pais Carlos e Orfélia, pela dedicação e esforço imensuráveis para que eu tivesse uma boa educação.

Aos colegas de laboratório: Ana Cristina, Belisa, Carolina, Cecília, Claudionor, Cleide, Diogo, Fábio, Felipe, Ilana, Jéssica, Poliana, Raquel, Ronaldo e Thais pela troca de idéias, orientações e conselhos que muito me ajudaram na realização deste trabalho.

Às funcionárias: Kazui, Maria Normandia (Norma) e Maria Helena, por proporcionarem todo apoio técnico necessário.

Aos secretários Marcos, Eliane e Fábia do Programa de Pós-Graduação Interunidades em Biotecnologia USP/Instituto Butantan/IPT, pela paciência e compreensão. 
“A maior necessidade do mundo é a de homens; homens que não se comprem nem se vendam; homens que no íntimo da alma sejam verdadeiros e honestos; homens que não temam chamar o pecado pelo seu nome exato; homens cuja consciência seja tão fiel ao dever como a bússola o é ao pólo; homens que permaneçam firmes pelo que é reto, ainda que caiam os céus." 


\section{RESUMO}

Quadros OF. Construção de sistemas bacterianos para a detecção de metais pesados em amostras ambientais. [tese (Doutorado em Biotecnologia)]. São Paulo (Brasil): Instituto de Ciências Biomédicas da Universidade de São Paulo; 2011.

Para a obtenção de biossensores bacterianos para os metais mercúrio, arsênio e chumbo, fragmentos dos operons mer, ars e pbr foram amplificados por PCR, a partir do DNA da bactéria Cupriavidus metallidurans CH34. Estes fragmentos de DNA foram inseridos à montante do gene EGFP, no plasmídeo pBB-EGFP, obtendo-se os plasmídeos pGHg, pGAs e pGPb, que foram clonados em C. metallidurans CH34 e Escherichia coli DH5 $\alpha$. As linhagens recombinantes foram incubadas em diferentes concentrações dos metais e analisadas quanto à emissão de fluorescência empregando-se microscopia e citometria de fluxo. As linhagens recombinantes C. metallidurans CH34 / pGHg e E. coli DH5 / pGHg, C. metallidurans CH34 / pGAs e C. metallidurans CH34 / pGPb permitiram a determinação de diferentes concentrações de mercúrio, arsênio e chumbo, respectivamente. Os resultados obtidos indicam forte potencial de aplicação para rápidos diagnósticos de águas contaminadas com estes metais pesados tóxicos.

Palavras-chave: Bactérias. Bioluminescência. Biotecnologia. Meio ambiente. Metais pesados. Regulação gênica. 


\begin{abstract}
Quadros OF. Construction of bacterial systems for the detection of heavy metals in environmental samples. [Ph. D. thesis (Biotechnology)]. São Paulo (Brasil): Instituto de Ciências Biomédicas da Universidade de São Paulo; 2011.

To obtain bacterial biosensors for metals mercury, arsenic and lead, fragments of operons mer, ars, and pbr were amplified by PCR from the DNA of the bacteria Cupriavidus metallidurans CH34. These DNA fragments were inserted upstream of the EGFP gene in the pBB-EGFP plasmid, obtaining plasmids pGHg, pGAs and pGPb, which were cloned in $C$. metallidurans CH34 and E. coli DH5 $\alpha$. The recombinant strains were incubated in different concentrations of metals and analyzed for fluorescence emission employing microscopy and flow cytometry. The recombinant strains C. metallidurans CH34/pGHg and E. coli DH5a/pGHg; C. metallidurans CH34/pGAs; and, C. metallidurans CH34/pGPb allowed the determination of different concentrations of mercury, arsenic and lead, respectively. The results indicate strong potential for application for quick diagnosis of waters contaminated with these toxic heavy metals.
\end{abstract}

Keywords: Bacteria. Bioluminescence. Biotechnology. Environment. Gene regulation. Heavy metals. 


\section{LISTA DE TABELAS}

Tabela 1 - O potencial tóxico dos metais pesados ao organismo humano e as principais fontes poluidoras.

Tabela 2 - Componentes biológicos empregados na construção de biossensores baseados em microrganismos geneticamente modificados.

Tabela 3 - Linhagens bacterianas utilizadas neste trabalho. .41

Tabela 4 - Sequência dos oligonucleotídeos empregados para amplificação por PCR.........42

Tabela 5 - Plasmídeos utilizados neste trabalho. .42

Tabela 6 - Capacidade de quantificação dos biossensores bacterianos construídos neste trabalho . .76

Tabela 7 - Comparação dos valores obtidos neste trabalho com valores de outros autores 


\section{LISTAS DE ILUSTRAÇÕES}

Figura 1 - Diferentes metodologias e equipamentos utilizados na detecção e/ou quantificação de sinais gerados pelos biossensores..

Figura 2 - Esquema da contrução de um biossensor bacteriano. .25

Figura 3 - Representação esquemática da Proteína Verde Fluorescente. .28

Figura 4 - Esquema do plasmídeo pBB-EGFP. .29

Figura 5 - Representação esquemática de operons mer de diferentes bactérias. .32

Figura 6 - Representação esquemática do sistema de resistência a $\mathrm{Hg}^{2+}$ em $C$. metallidurans CH34. Na parte inferior da figura estão representados os genes do operon mer presente nos plasmídeos pMOL28 e pMOL30 e na região cromossomal. As flechas indicam o sentido de transcrição dos genes. Na parte superior da figura estão indicadas as possíveis proteínas codificadas. Íons $\mathrm{Hg}^{2+}(\bullet)$ são transportados para o interior da célula pelas proteínas MerP/MerT. MerA reduz íons $\mathrm{Hg}^{2+}$ a $\mathrm{Hg}^{0}$, utilizando NADPH. O mercúrio metálico $\left(\mathrm{Hg}^{0}\right)$ é volátil e difunde-se para o meio exterior da célula. Íons $\mathrm{Hg}^{2+}$ livres ligam-se à MerR, provocando alteração da conformação MerR-MerD e consequentemente ativação do operon.

Figura 7 - Esquema da organização do operons ars de: A) E. coli: plasmídeo R773 e cromossômico de E. coli K12 e do plasmídeo pI258 de Staphylococcus spp.; B) Operon ars do cromossomo 1 de C. metallidurans CH34..

Figura 8 - A) Modelo do operon pbr de C. metallidurans CH34 que codifica resistência aos íons $\mathrm{Pb}^{2+}$. Estão indicados os genes: $p b r T$ (captura de $\mathrm{Pb}^{2+}$ ), $p b r R$ (regulador do operon), $\operatorname{pbrA}$ (ATPase do efluxo de $\mathrm{Pb}^{2+}$ ), $p b r B$ (função ainda desconhecida), pbrC (peptidase sinal), pbrD (seqüestro de $\mathrm{Pb}^{2+}$ ). B) Parte da seqüência do operon pbr do plasmídeo pMOL30 de C. metallidurans CH34, destacando o início e o fim do gene $p b r R$ e a região operadora/promotora.

Figura 9 - A) Esquema da construção do plasmídeo pTZ-Mer; B) Perfis de migração dos fragmentos de DNA analisados em gel de agarose $0,8 \%$, corado com brometo de etídio, submetido à corrida eletroforética, onde, 1: Marcador de tamanho molecular - Ladder 1kb 50ng/ $\mu \mathrm{L}$ (Fermentas); 2 e 4: pTZ-Mer digerido com NdeI; 3 e 5: pTZ-Mer digerido com NdeI e XhoI. 
Figura 10 - A) Esquema da contrução do plasmídeo pTZ-Mer e gel de agarose $0,8 \%$, corado com brometo de etídio, submetido à corrida eletroforética, onde 1 : Ladder 1Kb Fermentas, 2: pTZ-Mer digerido com NdeI, 3 e 4: pTZ-Mer digerido com NdeI e BamHI; B) Esquema da construção do plasmídeo biossensor de íons mercúrio pGHg; C) Perfis de migração dos fragmentos de DNA em gel de agarose $0,8 \%$, corado com brometo de etídio, submetido à corrida eletroforética, onde 1 : Ladder $1 \mathrm{~Kb}$ Fermentas, 2: pGHg digerido com NdeI, 3: pGHg digerido com NdeI e BamHI, 4: pGHg digerido com XhoI e BamHI; D) Células recombinantes de $E$. coli DH5 / pGHg fluorescendo na presença de mercúrio (aumento de 1000X, microscopia de fluorescência, utilizando uma lâmpada de vapor de mercúrio).

Figura 11 - Gráfico das diferentes intensidades de fluorescência do clone $C$. metallidurans $\mathrm{CH} 34 / \mathrm{pGHg}$ inoculado em $\mathrm{H}_{2} \mathrm{O}$, com diferentes concentrações de $\mathrm{HgCl}_{2}$, no intervalo de tempo de $2 \mathrm{~h}, 3 \mathrm{~h}, 4 \mathrm{~h}$ e $24 \mathrm{~h}$, incubado à $28{ }^{\circ} \mathrm{C}$.

Figura 12 - Gráfico das diferentes intensidades de fluorescência do clone $C$. metallidurans $\mathrm{CH} 34 / \mathrm{pGHg}$ inoculado em Caldo Nutriente, com diferentes concentrações de $\mathrm{HgCl}_{2}$, no intervalo de tempo de 2 h, 3 h, 4 h e 24 h, incubado à $28{ }^{\circ} \mathrm{C}$.

Figura 13 - Gráfico das diferentes intensidades de fluorescência do clone $E$. coli $\mathrm{DH} 5 \alpha / \mathrm{pGHg}$ inoculado em $\mathrm{H}_{2} \mathrm{O}$, com diferentes concentrações de $\mathrm{HgCl}_{2}$, no intervalo de tempo de 2 h, 3 h, 4 h e 24 h, incubado à $37^{\circ} \mathrm{C}$.

Figura 14 - Gráfico das diferentes intensidades de fluorescência do clone E. coli $\mathrm{DH} 5 \alpha / \mathrm{pGHg}$ inoculado em Caldo Nutriente, com diferentes concentrações de $\mathrm{HgCl}_{2}$, no intervalo de tempo de $2 \mathrm{~h}, 3 \mathrm{~h}, 4$ h e $24 \mathrm{~h}$, incubado à $37^{\circ} \mathrm{C}$

Figura 15 - A) Esquema da construção do plasmídeo pTZ-Ars; B) Perfis de migração dos fragmentos de DNA analisados em gel de agarose $0,8 \%$, corado com brometo de etídio, submetido à corrida eletroforética, onde, 1: Marcador de tamanho molecular - Ladder $1 \mathrm{~kb} 50 \mathrm{ng} / \mu \mathrm{L}$ (Fermentas); 2: pTZ-Ars digerido com NdeI e XhoI; 3: pTZ-Ars digerido com NdeI.

Figura 16 - A) Esquema da construção dos plasmídeos pGAs; B) Perfis de migração dos fragmentos de DNA em gel de agarose $0,8 \%$, corado com brometo de etídio, submetido à corrida eletroforética, onde, 1: Marcador de tamanho molecular - Ladder $1 \mathrm{~kb} 50 \mathrm{ng} / \mu \mathrm{L}$ (Fermentas); 2 pGAs-Cm não digerido; 3: pGAs-Cm digerido com NdeI; 4- pGAs-Cm digerido com NdeI e SacI.

Figura 17 - Gráfico das diferentes intensidades de fluorescência do clone $C$. metallidurans $\mathrm{CH} 34 / \mathrm{pGAs}$ inoculado em $\mathrm{H}_{2} \mathrm{O}$, em concentrações variadas de $\mathrm{Na}_{2} \mathrm{HAsO}_{4} \cdot 7 \mathrm{H}_{2} \mathrm{O}$, no intervalo de tempo de $2 \mathrm{~h}, 3 \mathrm{~h}, 4 \mathrm{~h}$ e $24 \mathrm{~h}$, incubado à $28{ }^{\circ} \mathrm{C}$. .

Figura 18 - Gráfico das diferentes intensidades de fluorescência do clone $C$. metallidurans CH34/pGAs inoculado em Caldo Nutriente, em concentrações variadas de $\mathrm{Na}_{2} \mathrm{HAsO}_{4} .7 \mathrm{H}_{2} \mathrm{O}$, no intervalo de tempo de $2 \mathrm{~h}$, 3h, 4h e $24 \mathrm{~h}$, incubado à $28{ }^{\circ} \mathrm{C}$. 
Figura 19 - Gráfico das diferentes intensidades de fluorescência do clone $E$. coli DH5 $\alpha$ CH34/pGAs inoculado em $\mathrm{H}_{2} \mathrm{O}$, em concentrações variadas de $\mathrm{Na}_{2} \mathrm{HAsO}_{4} .7 \mathrm{H}_{2} \mathrm{O}$, no intervalo de tempo de $2 \mathrm{~h}$, $3 \mathrm{~h}$, $4 \mathrm{~h}$ e $24 \mathrm{~h}$, incubado à $37{ }^{\circ} \mathrm{C}$.

Figura 20 - Gráfico das diferentes intensidades de fluorescência do clone $E$. coli $\mathrm{DH} 5 \alpha \mathrm{CH} 34 / \mathrm{pGAs}$ inoculado em Caldo Nutriente, em concentrações variadas de $\mathrm{Na}_{2} \mathrm{HAsO}_{4} \cdot 7 \mathrm{H}_{2} \mathrm{O}$, no intervalo de tempo de $2 \mathrm{~h}$, $3 \mathrm{~h}$, $4 \mathrm{~h}$ e $24 \mathrm{~h}$, incubado à $37{ }^{\circ} \mathrm{C}$

Figura 21 - A) Esquema da construção do plasmídeos pTZ-Pbr; B) Perfis de migração dos fragmentos de DNA em gel de agarose $0,8 \%$, corado com brometo de etídio, submetido à corrida eletroforética, onde, 1 e 8: Marcador de tamanho molecular - Ladder $1 \mathrm{~kb} 50 \mathrm{ng} / \mu \mathrm{L}$ (Fermentas); 2 a 7 pTZ-Pbr digeridos, sendo: 2NdeI; 3- NdeI e SacI; 4- NdeI e XbaI; 5- XbaI; 6- BamHI.; 7- NdeI e BamHI.

Figura 22 - A) Esquema da construção do plasmídeo pGPb; B) Perfis de migração dos fragmentos de DNA em gel de agarose 0,8\%, corado com brometo de etídio, submetido à corrida eletroforética, onde, 1: Marcador de tamanho molecular Ladder $1 \mathrm{~kb} 50 \mathrm{ng} / \mu \mathrm{L}$ (Fermentas); 2 a 8 plasmídeos pGPb digeridos com NdeI .68

Figura 23 - Gráfico das diferentes intensidades de fluorescência do clone $C$. metallidurans $\mathrm{CH34/pGPb}$ inoculado em $\mathrm{H}_{2} \mathrm{O}$, em concentrações variadas de $\mathrm{Pb}\left(\mathrm{NO}_{3}\right)_{2}$, no intervalo de tempo de $2 \mathrm{~h}, 3 \mathrm{~h}, 4 \mathrm{~h}$ e $24 \mathrm{~h}$, incubado à $28{ }^{\circ} \mathrm{C}$.

Figura 24 - Gráfico das diferentes intensidades de fluorescência do clone $C$. metallidurans $\mathrm{CH} 34 / \mathrm{pGPb}$ inoculado em Caldo Nutriente, em concentrações variadas de $\mathrm{Pb}\left(\mathrm{NO}_{3}\right)_{2}$, no intervalo de tempo de $2 \mathrm{~h}$, 3h, $4 \mathrm{~h}$ e $24 \mathrm{~h}$, incubado à $28^{\circ} \mathrm{C}$

Figura 25 - Gráfico das diferentes intensidades de fluorescência do clone $E$. coli DH5 $\alpha /$ pGPb inoculado em $\mathrm{H}_{2} \mathrm{O}$, em concentrações variadas de $\mathrm{Pb}\left(\mathrm{NO}_{3}\right)_{2}$, no intervalo de tempo de $2 \mathrm{~h}, 3 \mathrm{~h}, 4 \mathrm{~h}$ e $24 \mathrm{~h}$, incubado à $37{ }^{\circ} \mathrm{C}$

Figura 26 - Gráfico das diferentes intensidades de fluorescência do clone E. coli DH $5 \alpha / \mathrm{pGPb}$ inoculado em Caldo Nutriente, em concentrações variadas de $\mathrm{Pb}\left(\mathrm{NO}_{3}\right)_{2}$, no intervalo de tempo de $2 \mathrm{~h}$, $3 \mathrm{~h}$, $4 \mathrm{~h}$ e $24 \mathrm{~h}$, incubado à $37^{\circ} \mathrm{C}$

Figura 27 - Ilustração da técnica empregada onde as regiões operadora/ promotoras e os genes sensores foram clonados à montante da região estrutural do gene EGFP 


\section{LISTA DE ABREVIATURAS E SIGLAS}

Amp: ampicilina

$\mathrm{Cm}$ : gene que confere resistência ao cloranfenicol

DNA: ácido desoxirribonucléico (“Deoxyribonucleic acid”)

dNTPs: desoxirribonucleotídeos trifosfatados (“Deoxynucleotide triphosphates”)

EcoRI: endonuclease de restrição I de Escherichia coli RY13

EDTA: ácido etilenodiamino tetracético (“Ethylene diamine tetracetic acid”)

EGFP: proteina verde fluorescente realçada (“enhanced green fluorescent protein”)

FACS: "Fluorescence-Activated Cell-Sorting"

GFP: gene codificador da proteina verde fluorescente ("green fluorescent protein”)

IPTG: isopropil- $\beta$-D-tiogalactopiranosídeo (“Isopropyl $\beta$-D-1-thiogalactopyranoside”)

lacZ: gene codificador da $\beta$-D-galactosidase

LB: meio de cultura Luria-Bertani

luc: gene codificador da luciferase em eucariotos

lux: gene codificador da luciferase em procariotos

MCS: múltiplo sítio de clonagem

merA: gene codificador da proteína reductase MerA

merD: gene codificador da proteína MerD (regulação secundária do operon Mer)

merP: gene codificador da proteína periplasmática MerP (se liga ao íon mercúrio)

merR: gene codificador da proteína MerR (activadora/repressora do operon mer)

merT: gene codificador da proteína MerT de transporte do íon mercúrio

NADPH: nicotinamida adenina dinucleótido fosfato

NdeI: endonuclease de restrição I de Neisseria denitrificans

o/p: região operadora / promotora de uma operon

pb: pares de bases

PCR: reação em cadeia da polimerase

pH: potencial hidrogeniônico

PstI: endonuclease de restrição I de Providencia stuartii 164

RNase: ribonuclease

SacI: endonuclease de restrição I de Streptomyces achromogenes

SacII: endonuclease de restrição II de Streptomyces achromogenes 
SalI: endonuclease de restrição I de Streptomyces albus G

SDS: dodecil sulfato de sódio ("sodium dodecyl sulfate”)

SOC: meio de cultura para transformação bacteriana ("Super Optimal Catabolite”)

TBE: tampão Tris, ácido bórico e EDTA

TE: tampão Tris e EDTA

Tris: tris-hidroximetil-aminometano (“trishydroxymethylaminomethane”)

UV: radiação ultravioleta

$\mathrm{X}$ : vezes

XGal: 5-bromo-4-cloro-3-indol- $\beta$-D-Galactopiranosídeo

XhoI: endonuclease de restrição I de Xanthomonas holcicola 


\section{LISTA DE SÍMBOLOS}

\%: porcentagem

$\sim$ : aproximadamente

${ }^{\circ} \mathrm{C}$ : graus Celsius

$\mu$ FD: microfarad (capacitância)

$\mu g$ : micrograma

$\mu \mathrm{L}$ : microlitro

$\mu \mathrm{M}$ : micromol

Å: angstrom

$\mathrm{As}^{2+}:$ íon arsênio

$\mathrm{Cd}^{2+}:$ íon cádmio

$\mathrm{Co}^{2+}$ : íon cobalto

$\mathrm{CrO}_{4}^{-2}$ : íon cromato

$\mathrm{Cu}^{2+}:$ íon cobre

EGFP: proteina verde fluorescente realçada (“enhanced green fluorescent protein”)

$g$ : força centrífuga relativa à aceleração padrão de gravidade

h: horas

HCI: ácido clorídrico

$\mathrm{Hg}^{2+}$ : íon mercúrio

$\mathrm{HgCl}_{2}$ : cloreto de mercúrio

$\mathrm{kb}$ : quilo bases

KDa: quilo Dalton

L: litro

M: mol

mg/L: miligramas por litro

mg: miligrama

MgCl: cloreto de magnésio

mL: mililitro

mM: milimol

$\mathrm{Mn}^{2+}:$ íon manganês

$\mathrm{NaCl}$ : cloreto de sódio

$\mathrm{NaOH}$ : hidróxido de sódio 
nM: nanomol

$\mathrm{Pb}^{2+}$ : íon chumbo

pM: picomol

$\mathrm{Se}^{2+}$ : íon selênio

$\mathrm{U}^{2+}$ : íon urânio

$\mathrm{V}$ : volts

$\mathrm{Zn}^{2+}$ : íon zinco

$\Omega$ : ohms (resistência) 


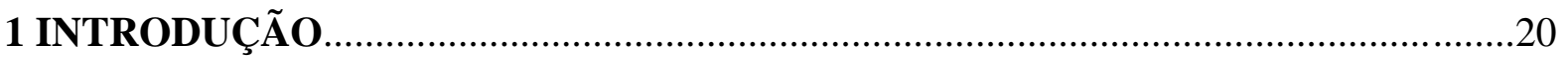

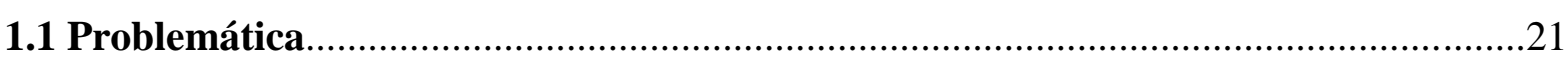

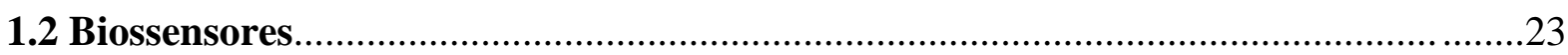

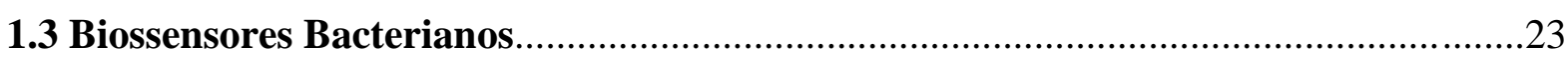

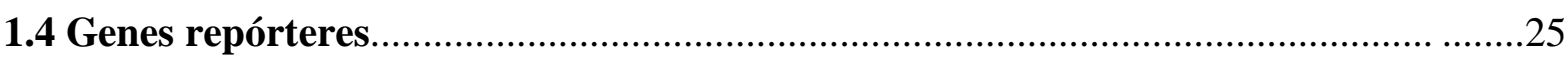

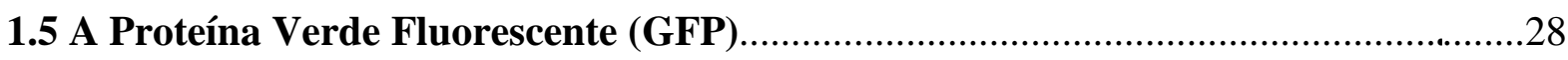

1.6 Genes biossensores de metais pesados...................................................................30

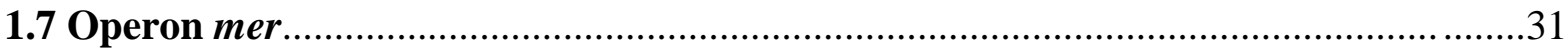

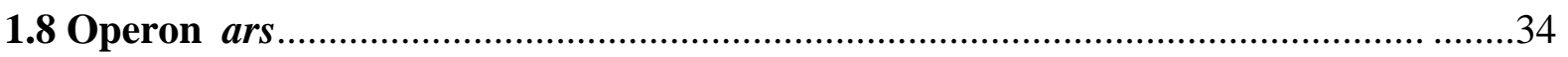

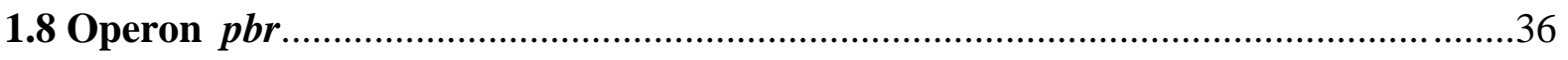

2 OBJETIVOS

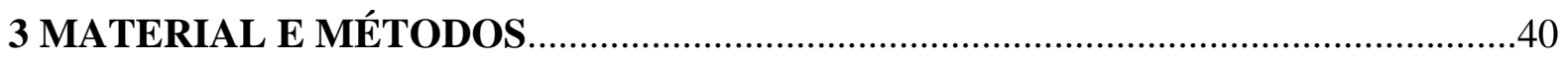

3.1 Material biológico....................................................................................................4

3.2 Reagentes e soluções...............................................................................................4

3.3 Meios de cultura e condições de crescimento bacteriano ................................................4

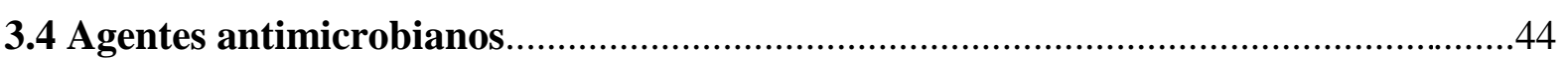

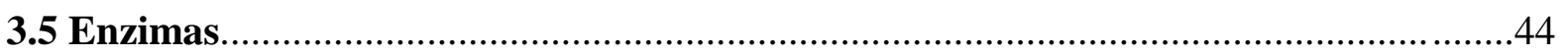

3.6 Extração e purificação de DNA plasmidial de E.coli.....................................................45

3.6.1 Minipreparação de DNA plasmidial - "MiniPrep”...........................................................45

3.6.2 Maxipreparação de DNA plasmidial - "MaxiPrep”.........................................................45

3.7 Isolamento e manipulação de megaplasmídeo............................................................46

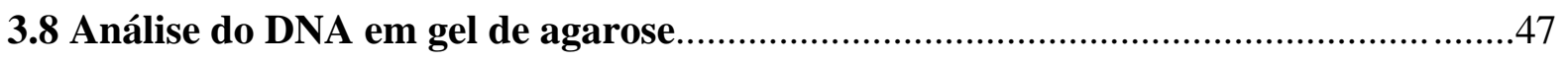

3.9 Purificação de fragmentos de DNA em gel de agarose …………………….............47

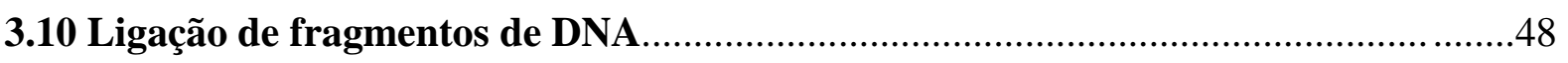

3.11 Preparo de células bacterianas competentes...........................................................48

3.12 Transformação de bactérias por eletroporação..........................................................49

3.13 Amplificação de fragmentos de DNA por PCR............................................................49

3.14 Avaliação biológica das bactérias recombinantes com os metais pesados.................50

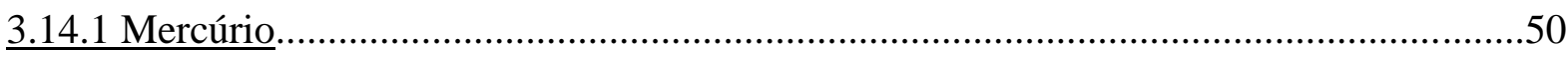

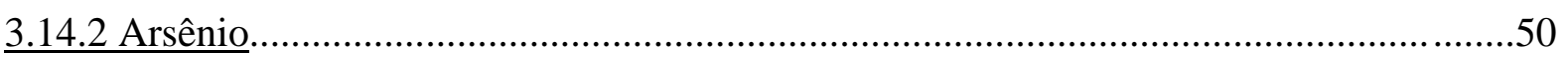

3.14.3 Chumbo 


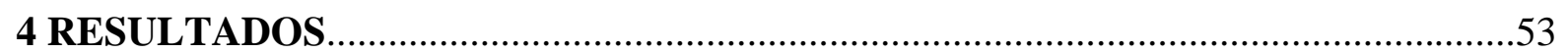

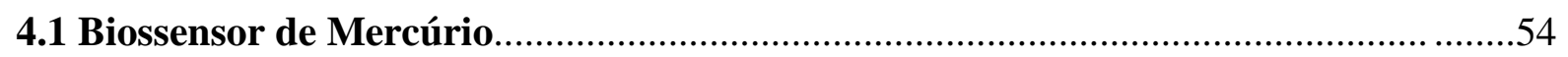

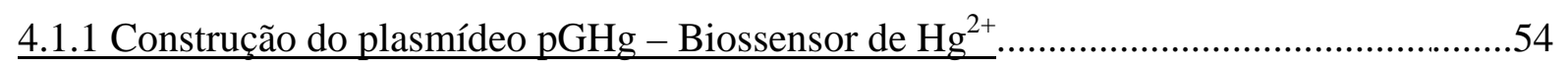

4.1.2 Análise quantitativa da expressão do gene EGFP dos clones recombinantes

E. coli DH5 $\alpha$ / pGHg e C. metallidurans CH34 / pGHg.................................................57

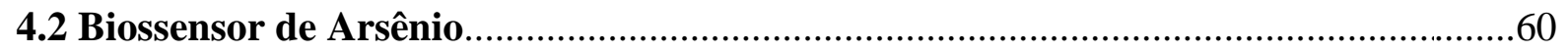

4.2.1 Contrução do plasmídeo pGAs - Biossensor de $\mathrm{As}^{3+}$..................................................60

4.2.2 Análise quantitativa da expressão do gene EGFP dos clones recombinantes

E. coli DH5 $\alpha$ / pGAs e C. metallidurans CH34 / pGAs.................................................62

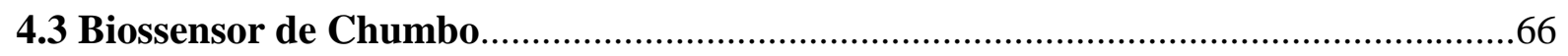

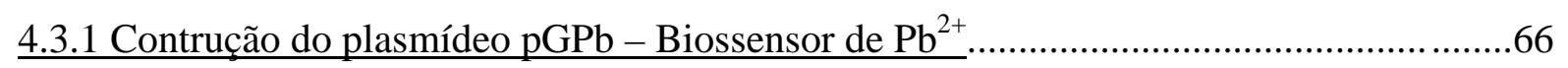

4.3.2 Análise quantitativa da expressão do gene EGFP dos clones recombinantes

E. coli DH5a / pGPb e C. metallidurans CH34 / pGPb..............................................69

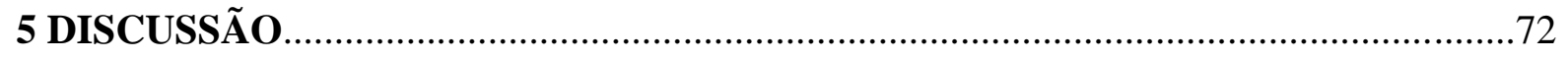

5.1 Expressão do gene EGFP nos três biossensores bacterianos....................................73

5.2 Operons específicos de resistência são viáveis para a obtenção de

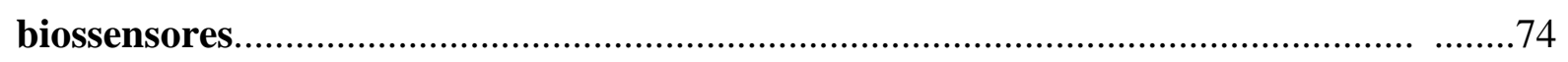

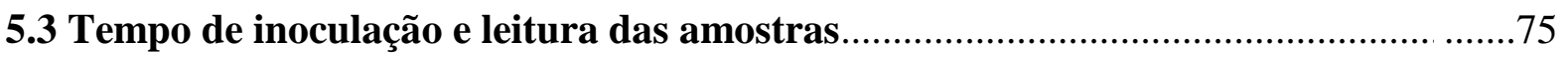

5.4 Viabilidade de inoculação dos biossensores bacterianos em água..............................75

5.5 Aplicabilidade na quantificação dos biossensores frente aos val

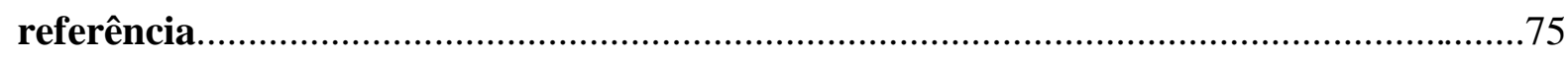

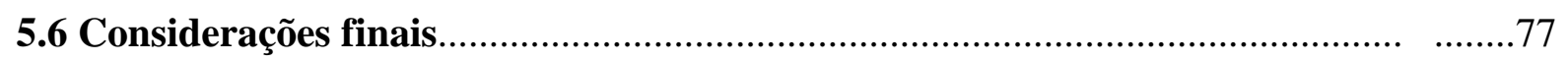

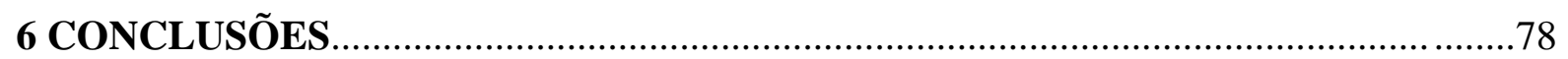

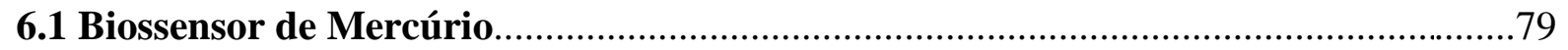

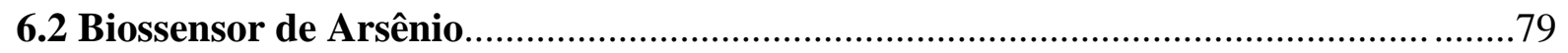

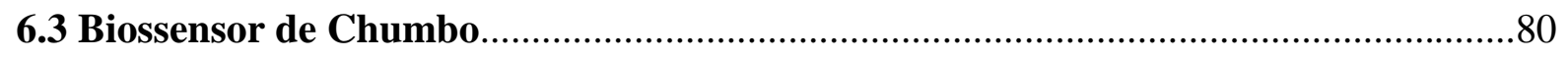

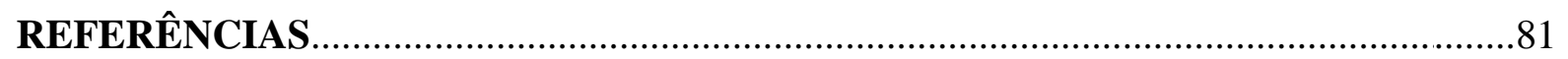




\subsection{Problemática}

O extrativismo mineral, atividades industriais, agropecuárias e esgotos domésticos são grandes responsáveis pela contaminação ambiental por metais pesados. O emprego de mercúrio metálico na extração de ouro em garimpos acarreta a liberação de toneladas deste metal tóxico no meio ambiente. Dados extraoficiais mostram que, nos últimos 15 anos, cerca de 1500 a 3000 toneladas de mercúrio metálico foram usadas na extração de ouro na Amazônia. Acredita-se que, do total empregado, mais de 62\% foi lançado ao ambiente (Vieira e Passarelli, 1996). De um modo geral, a atividade de extração de minérios como ferro, cobre, alumínio e outros que se encontram naturalmente presentes em montanhas promovem a exposição ambiental de camadas soterradas há muitos milênios. Tal exposição promove a liberação, oxidação e, conseqüentemente, a solubilização e biodisponibilização de íons de metais pesados tóxicos para os veios de água.

Todos os metais e seus compostos possuem toxicidade, ou seja, a capacidade inerente que um elemento químico tem para causar efeitos adversos sobre os organismos vivos (Goyer, 1997). O fator-chave é o grau de exposição que afeta o organismo. A exposição está relacionada com o tempo e a concentração do composto envolvido. Os efeitos tóxicos dos metais pesados e dos seus compostos são determinados pela sua conversão em uma forma biodisponível. Ao ingressar no ambiente, o íon pode se ligar com a matéria orgânica, reduzindo a quantidade que está biodisponível (Muniz e Oliveira-Filho, 2006).

Várias definições de metais pesados podem ser encontradas na literatura; no entanto, há um consenso de que metais pesados sejam elementos químicos com densidade igual ou maior que 5 g/cm³ (Nies, 1999; Piveli e Kato, 2005; Roane e Pepper, 2000). Considerando-se essa definição, muitos destes íons metálicos como ferro (Fe), molibdênio (Mo) e manganês (Mn) são importantes elementos-traço com baixa toxicidade, enquanto zinco (Zn), níquel (Ni), cobre $(\mathrm{Cu})$, vanádio $(\mathrm{V})$, cobalto $(\mathrm{Co})$, tungstênio $(\mathrm{W})$ e crômio $(\mathrm{Cr})$ são de moderada importância como elementos-traço e apresentam toxicidade em concentrações pouco acima das fisiológicas. Por fim, arsênio (As), prata (Ag), antimônio (Sb), cádmio (Cd), mercúrio $(\mathrm{Hg})$, chumbo $(\mathrm{Pb})$ e urânio (U) não são essenciais para o crescimento celular, sendo extremamente tóxicos, mesmo em baixas concentrações (Nies, 1999).

A portaria $n^{\circ} 518$ (Brasil, 2004) e a resolução n 357 (CONAMA ,2005) dispõe sobre a classificação e diretrizes ambientais para o enquadramento dos níveis de metáis pesados em corpos de água superficiais, bem como estabelece as condições e padrões de potabilidade, 
devido à sua toxicidade e persistência na natureza. O potencial tóxico dos metais pesados ao organismo humano é diverso e está resumido na Tabela 1, que mostra as principais fontes poluidoras e os efeitos na saúde humana (ICSCs, 2011).

Tabela 1 - O potencial tóxico dos metais pesados ao organismo humano e as principais fontes poluidoras.

\begin{tabular}{|c|c|c|c|}
\hline Íon & Principais Fontes Poluidoras* & Efeitos no homem** & Potabilidade*** \\
\hline $\begin{array}{l}\text { Arsênio } \\
\text { (As) }\end{array}$ & $\begin{array}{l}\text { Herbicidas, Inseticidas, Fungicidas, } \\
\text { Mineração, Indústria de vidros, tintas e } \\
\text { corantes. }\end{array}$ & $\begin{array}{c}\text { Câncer, Intoxicação e Morte (130 } \\
\text { mg). }\end{array}$ & $\begin{array}{c}0,01 \mathrm{mg} / \mathrm{L} \\
(0,1335 \mathrm{mM})\end{array}$ \\
\hline $\begin{array}{l}\text { Cádmio } \\
\text { (Cd) }\end{array}$ & $\begin{array}{l}\text { Efluentes industriais, Galvanoplastia, } \\
\text { Produção de Pigmentos, Equipamentos } \\
\text { eletrônicos, Lubrificantes, Acessórios } \\
\text { fotográficos, Inseticidas e } \\
\text { Combustíveis fósseis. }\end{array}$ & $\begin{array}{l}\text { Anemia, Retardamento do } \\
\text { crescimento, Morte (9 gramas), } \\
\text { Disfunção renal, Hipertensão, } \\
\text { Arteriosclerose, Câncer e Doenças } \\
\text { crônicas. }\end{array}$ & $\begin{array}{c}0,005 \mathrm{mg} / \mathrm{L} \\
(0,0445 \mathrm{mM})\end{array}$ \\
\hline $\begin{array}{l}\text { Chumbo } \\
\text { (Pb) }\end{array}$ & $\begin{array}{l}\text { Efluentes industriais, Tabaco, Tintas, } \\
\text { Tubulações, Metalurgia e Indústria de } \\
\text { Eletrodeposição. }\end{array}$ & $\begin{array}{l}\text { Saturnismo, Tontura, Irritabilidade, } \\
\text { Dor de cabeça, Perda de memória, } \\
\text { Deficiências musculares, Inflamação } \\
\text { gastrintestinal, Vômitos e Diarréias. }\end{array}$ & $\begin{array}{l}0,01 \mathrm{mg} / \mathrm{L} \\
(48,3 \mu \mathrm{M})\end{array}$ \\
\hline $\begin{array}{l}\text { Cobalto } \\
\text { (Co) }\end{array}$ & $\begin{array}{l}\text { Indústrias Química, Cerâmica, } \\
\text { Metalúrgica e de Óleo. }\end{array}$ & $\begin{array}{l}\text { Doenças pulmonares, Bócio, colapso } \\
\text { cardíaco e hipotireoidismo. }\end{array}$ & $\begin{array}{l}0,05 \mathrm{mg} / \mathrm{L} \\
(0,85 \mathrm{mM})\end{array}$ \\
\hline $\begin{array}{l}\text { Cobre } \\
(\mathrm{Cu})\end{array}$ & $\begin{array}{l}\text { Corrosão de tubulações, Esgotos } \\
\text { domésticos, Algicidas, Fungicidas, } \\
\text { Pesticidas, Mineração, Fundição e } \\
\text { Refinamento de metais. }\end{array}$ & Lesões no fígado e Intoxicação. & $\begin{array}{c}2,0 \mathrm{mg} / \mathrm{L} \\
(31,47 \mathrm{mM})\end{array}$ \\
\hline $\begin{array}{l}\text { Crômio } \\
\text { (Cr) }\end{array}$ & $\begin{array}{l}\text { Efluentes industriais, Produção de } \\
\text { alumínio e aço, Tintas, Pigmentos, } \\
\text { Explosivos, Papel e Fotografia. }\end{array}$ & Alergias, Câncer e Intoxicação. & $\begin{array}{c}0,05 \mathrm{mg} / \mathrm{L} \\
(0,962 \mathrm{mM})\end{array}$ \\
\hline $\begin{array}{l}\text { Mercúrio } \\
\text { (Hg) }\end{array}$ & $\begin{array}{l}\text { Pescados, Garimpos, Praguicidas, } \\
\text { Produção de cloro, Desinfetantes, } \\
\text { Pigmentos, Mineração, Esgotos, } \\
\text { Produtos odontológicos, Farmacêuticos } \\
\text { e Tintas. }\end{array}$ & $\begin{array}{l}\text { Morte (3-30 gramas), Vômitos, } \\
\text { Dores abdominais, Diarréia, } \\
\text { Osteoporose, Lesões cerebrais e } \\
\text { renais, Alterações psicológicas e } \\
\text { psicomotoras. }\end{array}$ & $\begin{array}{l}0,001 \mathrm{mg} / \mathrm{L} \\
(4,985 \mu \mathrm{M})\end{array}$ \\
\hline $\begin{array}{l}\text { Níquel } \\
\text { (Ni) }\end{array}$ & $\begin{array}{l}\text { Galvanoplastias, Mineração, Queima } \\
\text { de combustíveis fósseis, Fundição de } \\
\text { metal, Produção de ligas metálica e } \\
\text { Fabricação de alimentos. }\end{array}$ & $\begin{array}{l}\text { Câncer, Dermatites, Alterações } \\
\text { cardíacas e respiratórias. }\end{array}$ & $\begin{array}{l}0,025 \mathrm{mg} / \mathrm{L} \\
(0,426 \mathrm{mM})\end{array}$ \\
\hline $\begin{array}{l}\text { Zinco } \\
(\mathrm{Zn})\end{array}$ & $\begin{array}{l}\text { Galvanoplastias, Mineração, } \\
\text { Combustão de madeira, Incineração de } \\
\text { resíduos, Esgotos domésticos e } \\
\text { Produção de ferro e aço. }\end{array}$ & $\begin{array}{c}\text { Alterações respiratórias, gástricas e } \\
\text { cardíacas. }\end{array}$ & $\begin{array}{c}5,0 \mathrm{mg} / \mathrm{L} \\
(76,475 \mathrm{mM})\end{array}$ \\
\hline
\end{tabular}

A identificação da presença de metais pesados no ambiente pode ser realizada por ensaios químicos e/ou físico-químicos. Todavia, estes ensaios são laboriosos e caros. Uma 
nova proposta para a determinação da contaminação ambiental de metais pesados consiste na utilização de biossensores que são capazes de, não só fornecer resultados quantitativos, como também mostrar a disponibilidade biológica (biodisponibilidade) e assim, o efeito tóxico destes poluentes sobre o meio ambiente (Ramanathan et al., 1997). Desta forma, o desenvolvimento de um biossensor metal-específico vem sendo considerado um recurso chave para caracterizar um ambiente contaminado com metais pesados, bem como monitorar as ações de remediação desta área (de Lorenzo e Kuenen, 1999; Weitz et al., 2001). Sendo assim, este trabalho propôs desenvolver biossensores bacterianos para a detecção de metais pesados em amostras ambientais.

\subsection{Biossensores}

Os biossensores podem ser definidos como dispositivos analíticos, cujo sistema de detecção da molécula-alvo é um componente biológico (Alfaya e Kubota, 2002). Os componentes biológicos podem ser organismos, tecidos, células, organelas, membranas, enzimas, receptores, anticorpos, ácidos nucléicos e macromoléculas orgânicas (Bhatia et al., 2000; Iwuoha et al., 2000; Turner et al., 1987; Zhang et al., 1991), que reconhecem a substância (Ex. íons de metais pesados) através de interações bioquímicas. Outro componente importante de um biossensor é o transdutor, que transforma o sinal biológico em um sinal analisável por um dispositivo físico-químico, gerando, por exemplo, a liberação de gases, emissão ou absorção de luz, emissão de calor, entre outras (Mulchandani e Bassi, 1995). Os biossensores podem ser classificados em biossensores ópticos, eletroquímicos, potenciométricos, termométricos, enzimáticos e microbianos. Diferentes metodologias e equipamentos são utilizados na deteç̧ão e/ou quantificação de sinais gerados pelos biossensores (Figura 1). São atributos dos sistemas biossensores: especificidade, sensibilidade, confiabilidade, portabilidade, análise em tempo real e simplicidade na operação (D'Souza, 2001).

\subsection{Biossensores Bacterianos}

Biossensores bacterianos podem ser constituídos de microrganismos não modificados ou geneticamente modificados. Os biossensores com microrganismos não modificados geneticamente são empregados para análise de substâncias poluentes em amostras ambientais 
e para determinação da demanda bioquímica de oxigênio (Lee et al., 1991, 1992). A aplicação mais comum de biossensores constituído de células microbianas naturais é a análise de toxicidade de amostras com organismos luminescentes como, por exemplo, o Vibrio fischeri e o Photobacterium phosphoreum. Em ambos organismos, a redução da intensidade da bioluminescência é utilizada para avaliar as alterações do metabolismo celular, quando o organismo é exposto a uma amostra ambiental, sendo a diminuição da intensidade da luz proporcional à toxicidade da amostra (Chang et al., 1981; Chatterjee e Meighen, 1995).

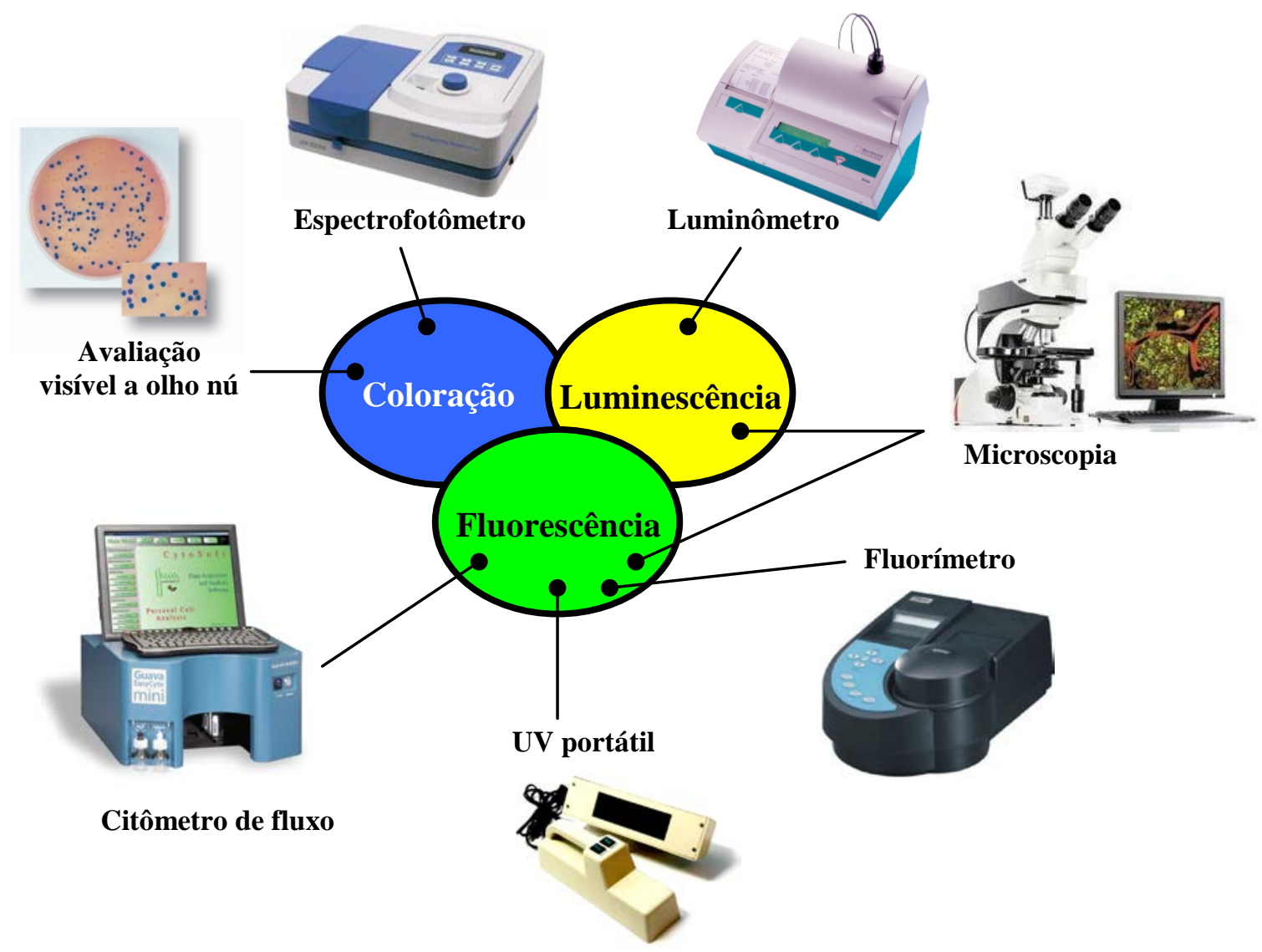

Figura 1 - Diferentes metodologias e equipamentos utilizados na deteç̧ão e/ou quantificação de sinais gerados pelos biossensores.

Por outro lado, microrganismos geneticamente modificados podem ser desenvolvidos para produzir sinais químicos, físicos ou biológicos, provenientes da produção de proteínas repórteres como a luciferase, $\beta$-galactosidase, fosfatase alcalina e proteínas fluorescentes (Tecon e Van der Meer, 2006). 
Para a construção genética de um biossensor bacteriano são necessários alguns componentes: um operador/promotor (o/p), o gene sensor, codificador da proteína que regula a expressão do promotor de interesse e um terceiro componente, um gene repórter (Figura 2). A síntese da proteína repórter é normalmente regulada pelo operador/promotor (Tecon e Van der Meer, 2006). Na Tabela 2 são apresentados alguns componentes biológicos empregados na construção de microrganismos biossensores geneticamente modificados para detecção e quantificação de íons de metais pesados.

\section{Biossensor Bacteriano}

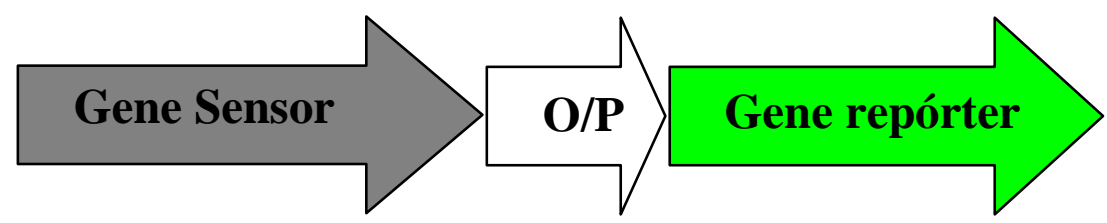

Figura 2 - Esquema da contrução de um biossensor bacteriano.

\subsection{Genes repórteres}

A tecnologia de gene repórter permite a construção de biossensores de manuseio simples. Os genes repórteres codificam a informação para a síntese de uma enzima cuja atividade possa ser facilmente detectada. No biossensor, estes genes são ligados a um promotor ativado pela substância de interesse (Ex.: poluente orgânico, metal pesado, composto de interesse, etc.). A quantidade de enzima produzida é proporcional à concentração da substância na amostra. Os principais genes codificadores de proteínas repórteres atualmente empregados neste tipo de trabalho são: lacZ, lucFF, lux e GFP (Magrisso, 2008).

Apesar desta variedade de genes repórteres mencionados, durante a caracterização de novos promotores, há dificuldades para obtenção de uma quantificação rápida, que possa ser feita sob situações adversas, tais como $\mathrm{pH}$ extremo e outras condições ambientais. Por este motivo, muitos autores têm utilizado a proteína repórter GFP, que apresenta uma grande versatilidade, conforme será descrito adiante. 


\begin{tabular}{|c|c|c|c|c|c|c|}
\hline Gene sensor & Metal & Genes Repórteres & Bactéria hospedeira & $\begin{array}{c}\text { Faixa de quantificação } \\
(\mathrm{mM})\end{array}$ & Tempo de incubação & Referência \\
\hline \multirow[t]{2}{*}{$\operatorname{ars} B$} & $\begin{array}{l}\mathrm{As}^{3+} \\
\mathrm{As}^{5+} \\
\mathrm{Bi} \\
\mathrm{Sb}\end{array}$ & blaZ & S. aureus & $\begin{array}{l}1-10 \\
10-100 \\
100-1000 \\
0,2-1\end{array}$ & $60 \mathrm{~min}$ & Ji e Silver (1992) \\
\hline & As & luxAB (V. fischeri) & E. coli & $0,01-1$ & $120 \min$ & Cai e Dubow (1997) \\
\hline \multirow[t]{9}{*}{$\operatorname{ars} R$} & $\begin{array}{l}\text { As } \\
\text { As }\end{array}$ & $\begin{array}{l}\text { lucFF } \\
\text { luxCDABE (V. fischeri) }\end{array}$ & E. coli & $\begin{array}{l}0,01-1 \\
0,01-1\end{array}$ & $8 \mathrm{~h}$ & Hakkila et al. (2002) \\
\hline & $\begin{array}{l}\mathrm{As} \\
\mathrm{Sb}\end{array}$ & lacZ & E. coli & $\begin{array}{l}0,1-100 \\
0,005-10\end{array}$ & $30 \mathrm{~min}$ & Ramanathan et al. (1998) \\
\hline & $\begin{array}{l}\mathrm{As}^{3+} \\
\mathrm{As}^{5+} \\
\mathrm{Cd} \\
\mathrm{Sb}\end{array}$ & lucFF & E. coli & $\begin{array}{l}0,033-1 \\
33-33000 \\
10-10000 \\
0,1-100\end{array}$ & $90 \min$ & Tauriainen et al. (1999) \\
\hline & As & luxAB (V. fischeri) & E. coli & $0,1-0,8$ & $60 \mathrm{~min}$ & Stocker et al. (2003) \\
\hline & As & luxAB (V. fischeri) & E. coli & $0,1-0,4$ & $60 \mathrm{~min}$ & Trang et al. (2005) \\
\hline & As & GFP (A. Victoria) & E. coli & $0,13-133$ & $12 \mathrm{~h}$ & Roberto et al. (2002) \\
\hline & As & lucGR (P. plagiophthalamus) & P. fluorescens & $0,1-10$ & $120 \min$ & Petanen et al. (2001) \\
\hline & $\begin{array}{l}\mathrm{Cd} \\
\mathrm{Sb}\end{array}$ & lucFF & S. aureus & $\begin{array}{l}0,5-5 \\
0,1-10\end{array}$ & $120 \min$ & Tauriainen et al. (1997) \\
\hline & $\begin{array}{l}\mathrm{As}^{3+} \\
\mathrm{As}^{5+} \\
\mathrm{Sb}\end{array}$ & GFP (A. Victoria) & E. coli & $\begin{array}{l}0,4-25 \\
1-50 \\
0,75-8\end{array}$ & $120 \min$ & Liao e Ou (2005) \\
\hline $\operatorname{ars} R D$ & $\begin{array}{l}\mathrm{As}^{3+} \\
\mathrm{Sb}\end{array}$ & $\operatorname{lacZ}$ & E. coli & $\begin{array}{l}0,5-100 \\
0,1-10\end{array}$ & $17 \mathrm{~h}$ & Scott et al. (1997) \\
\hline cadAC & $\mathrm{Cd}$ & blaz & S. aureus & $0,5-100$ & $90 \mathrm{~min}$ & Yoon et al. (1991) \\
\hline \multirow[t]{2}{*}{ cadC (S. aureus) } & $\begin{array}{l}\mathrm{Cd} \\
\mathrm{Pb} \\
\mathrm{Sb} \\
\mathrm{Sn}\end{array}$ & $\operatorname{lucF}$ & Bacillus subtilis & $\begin{array}{l}0,003-0,1 \\
1-10 \\
0,033-3,3 \\
33-1000\end{array}$ & 180 min & Tauriainen et al. (1998) \\
\hline & $\begin{array}{l}\mathrm{Zn} \\
\mathrm{Cd} \\
\mathrm{Pb} \\
\mathrm{Sb}\end{array}$ & GFP (A. Victoria) & E. coli & $\begin{array}{l}1-33 \\
0,0001-500 \\
0,01-10 \\
0,0001-10\end{array}$ & $120 \min$ & Liao et al. (2006) \\
\hline $\operatorname{chrB}$ & $\mathrm{Cr}$ & lacZ & C. metallidurans & $0,001-50$ & $8 \mathrm{~h}$ & Peitzsch et al. (1998) \\
\hline $\operatorname{chr} B$ & $\begin{array}{l}\mathrm{Cr}^{3+} \\
\mathrm{Cr}^{6+}\end{array}$ & luxCDABE (V. fischeri) & C. metallidurans & $\begin{array}{l}5-80 \\
2,5-40\end{array}$ & $90 \mathrm{~min}$ & Corbisier et al. (1999) \\
\hline $\operatorname{chr} A B$ & $\begin{array}{l}\mathrm{Cr}^{3+} \\
\mathrm{Cr}^{6+}\end{array}$ & lucFF & C. metallidurans & $\begin{array}{l}2-100 \\
0,04-1\end{array}$ & $120 \min$ & Ivask et al. (2002) \\
\hline cnrXYH & $\begin{array}{l}\mathrm{Co} \\
\mathrm{Ni} \\
\end{array}$ & luxDABE (V. fischeri) & C. metallidurans & $\begin{array}{l}9-400 \\
0,1-60\end{array}$ & $16 \mathrm{~h}$ & Tibazarwa et al. (2001) \\
\hline
\end{tabular}




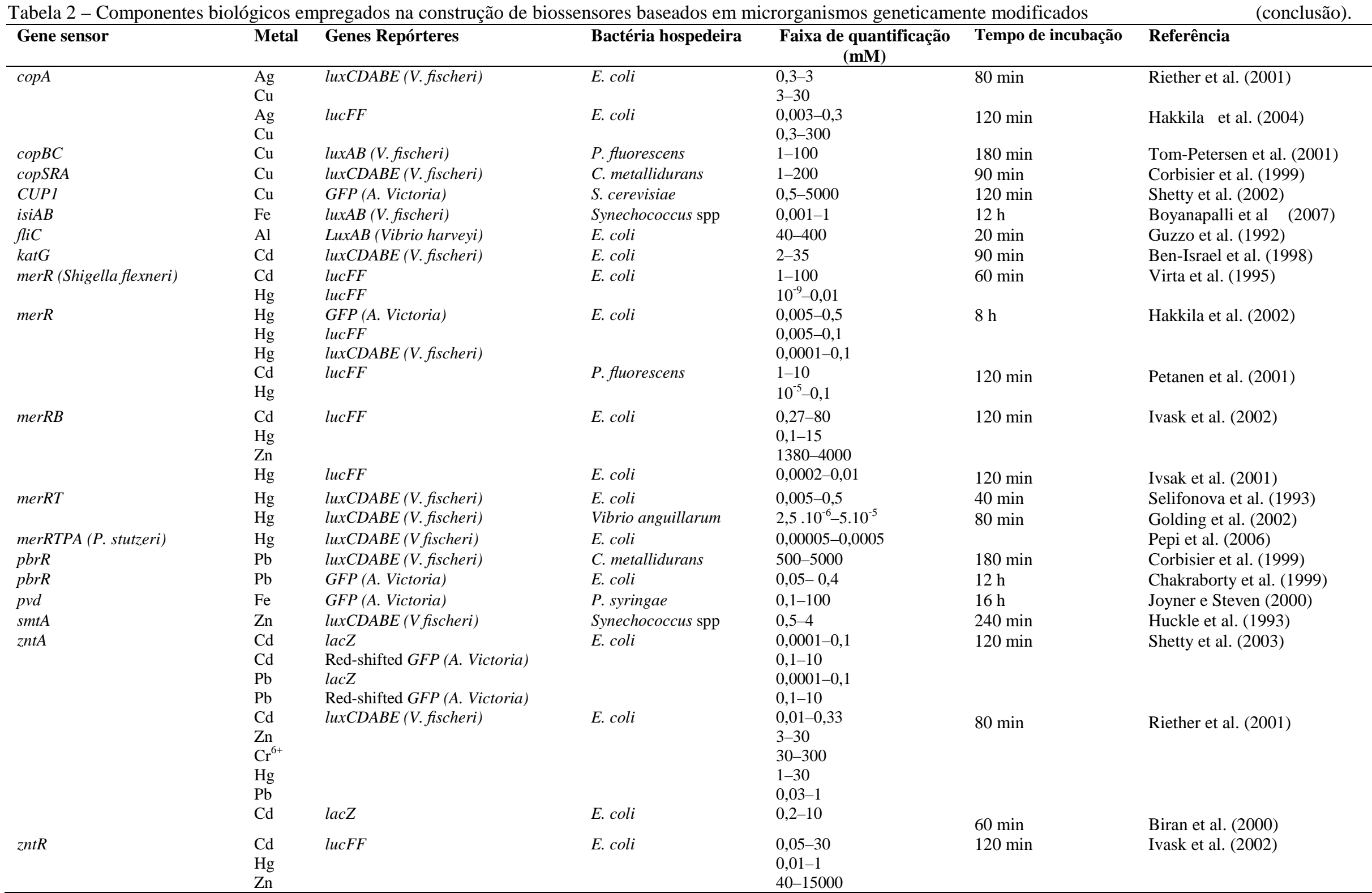

Fonte: Adapatado de Magrisso, 2008. 


\subsection{A Proteína Verde Fluorescente (GFP)}

A proteína verde fluorescente (GFP) é codificada pelo gene GFP da água-viva Aequorea victoria (Prasher et al., 1992). A GFP é um monômero de $30 \mathrm{KDa}$, com 238 aminoácidos. A estrutura da GFP é constituída de um cilindro com aproximadamente $24 \AA \hat{~ d e ~}$

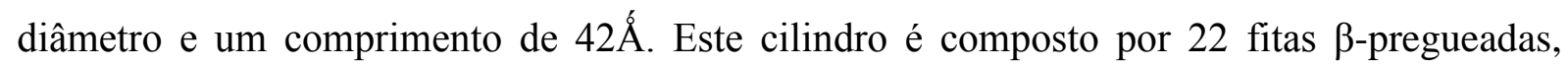
dentro das quais o cromóforo está localizado (Figura 3). As $\alpha$-hélices formam capas no topo e embaixo do cilindro e ainda protegem o cromóforo. A cavidade contendo o cromóforo possui muitos resíduos de cargas além de moléculas de água que auxiliam na manutenção das pontes de hidrogênio da estrutura (Tsien, 1998).

A proteína GFP selvagem absorve a luz azul no comprimento de onda de 395nm e emite luz verde em 510nm, tanto no organismo vivo quanto purificada em solução. A fluorescência da proteína GFP é produzida até a temperatura de $65^{\circ} \mathrm{C}$; é estável na presença de compostos desnaturantes, de proteases e na faixa de pH entre 6 a 12 (Ward et al., 1980). O gene GFP pode ser expresso em muitos organismos eucariontes ou procariontes (Errampalli et al., 1999). A proteína GFP pode ser utilizada como repórter para visualização da expressão gênica e localização subcelular de proteínas (Welsh e Kay, 1997).

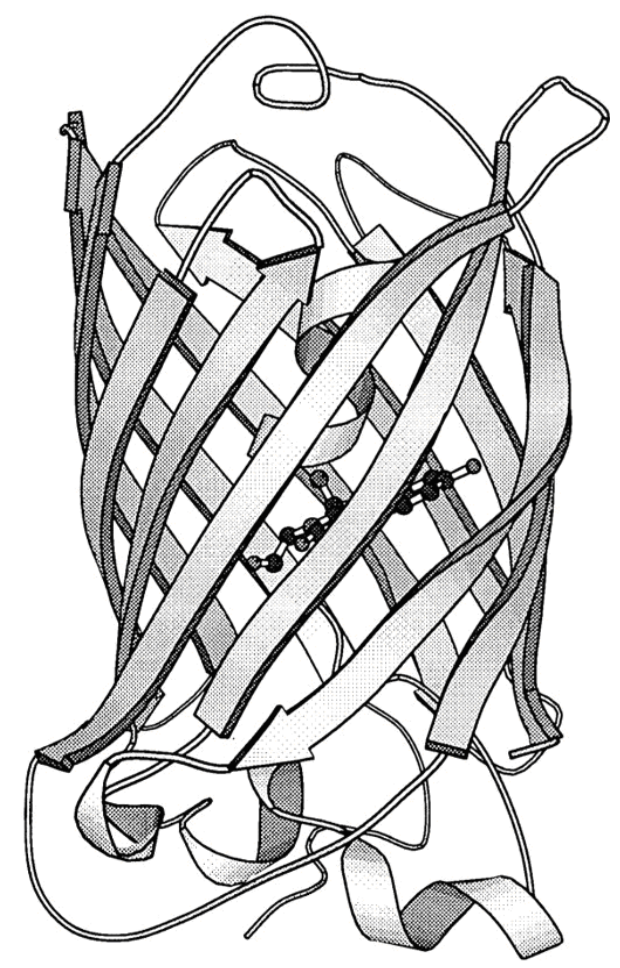

Figura 3 - Representação esquemática da Proteína Verde Fluorescente. Fonte: Tsien, 1998. 
A proteína “enhanced” GFP (EGFP) é uma proteína modificada derivada de GFP, mais estável (Clontech, 1996), com excitação em 488nm e emissão em 508nm de comprimento de onda, que apresenta um aumento de fluorescência da ordem de 35 vezes em relação à selvagem (Li et al., 1997). Exemplo da utilização gene para a monitoramento ambiental foi demonstrado por Wells et al., 2005, onde realizaram a fusão de um promotor bacteriano sensível a arsênio e o gene EGFP e testaram sua funcionalidade em Escherichia coli DH5 $\alpha$, mostrando que a bactéria tornou-se um biossensor de arsênio.

Neste trabalho, foi utilizado o plasmídeo pBB-EGFP (Quadros, 2007), que contém algumas características importantes para as estratégias propostas, tais como:

- Plasmídeo amplo-espectro para transformação de bactérias Gram-negativas;

- Gene de resistência ao cloranfenicol, possibilitando a clonagem em C. metallidurans;

- Possibilidade de transformação por conjugação;

- Múltiplos sítios de clonagens;

- Gene repórter EGFP;

- Sítio de clonagem NdeI (CATATG) à montante do gene EGFP, permitindo a clonagem das regiões operadoras/promotoras dos genes sensores antes do códon de transcrisão ATG.

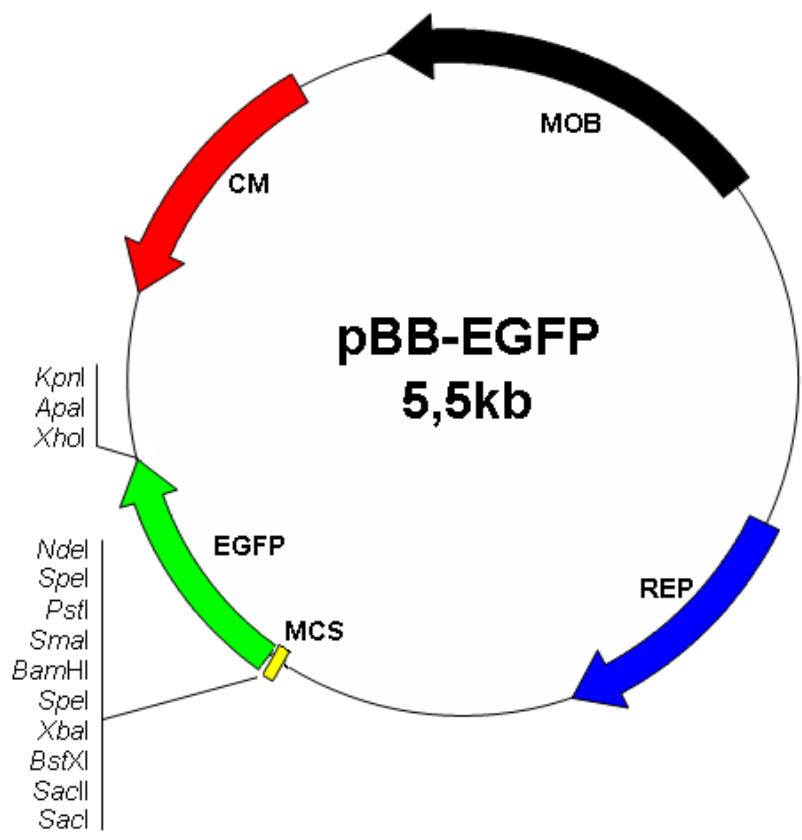

Figura 4 - Esquema do plasmídeo pBB-EGFP. 


\subsection{Genes biossensores de metais pesados}

Alguns trabalhos descrevem o uso de fragmentos aleatórios de DNA e bibliotecas genômicas na construção de biossensores de metais pesados (Dubow, 1998), mas a grande maioria dos relatos mais recentes aponta para uma escolha adequada de um gene sensor conhecido, como por exemplo, regiões regulatórias de operons de resistência bacteriana e/ou mecanismos de captação de metais pesados (Tabela 2). As bactérias têm participação considerável nas transformações iônicas dos metais, promevendo assim aumento de sua mobilidade (biolixiviação) ou sua imobilização (biorremediação). A resistência bacteriana aos íons de metais pesados resulta de mecanismos isolados ou simultâneos: precipitação extracelular, sequestro no envelope celular, precipitação e transformação redox intracelular (Brunis et al., 2000; Rosen et al., 1999). Esses mecanismos são ativos contra os efeitos tóxicos dos íons de metais pesados $\left(\mathrm{Pb}^{2+}, \mathrm{Hg}^{2+}, \mathrm{Cd}^{2+}, \mathrm{As}^{3+}, \mathrm{As}^{5+}, \mathrm{Sb}^{2+}, \mathrm{Ag}^{+}, \mathrm{Tl}\right)$; tanto quanto os metais essenciais, quando presentes em concentrações perigosamente elevadas para as células $\left(\mathrm{Zn}^{2+}, \mathrm{Fe}^{2+}, \mathrm{Fe}^{+}, \mathrm{Ni}^{2+}, \mathrm{Cu}^{2+}, \mathrm{Co}^{2+}, \mathrm{CrO}_{4}^{-2}\right)$ (Bontidean et al., 2000, 2004).

Dentre as bactérias resistentes a metais pesados, destaca-se a Cupriavidus metallidurans $\mathrm{CH} 34$, anteriormente conhecida como Alcaligenes eutrophus, Ralstonia eutropha, Ralstonia metallidurans CH34 e depois como Wautersia metallidurans CH34 (Vandamme et al., 2004). C. metallidurans é classificada como $\beta$-proteobacteria quimiolitotrófica facultativa, possui um cromossomo (3,9 Mb), um megaplasmídeo (2,6 Mb), e dois grandes plasmídeos: pMOL30 (234 kb) e pMOL28 (171 kb) (Monchy et al., 2006). Dentre todas as bactérias conhecidas, esta é a que apresenta os maiores índices de resistência a metais pesados $\left(\mathrm{Zn}^{2+}, \mathrm{Cd}^{2+}, \mathrm{Co}^{2+}, \mathrm{Ni}^{2+}, \mathrm{Cu}^{2+}, \mathrm{CrO}_{4}{ }^{-2}, \mathrm{Hg}^{2+}, \mathrm{Pb}^{2+}\right)$. Os genes codificadores das proteínas que conferem resistência a estes metais estão contidos nos plasmídeos e também no cromossomo (Diels et al., 2002; Grass et al., 2005; Mergeay et al., 2003; Taghavi et al., 1997).

Por conterem operons específicos de resistência para os metais mercúrio, arsênio e chumbo, neste trabalho, o DNA total de C. metallidurans CH34 foi escolhido como molde para obtenção dos fragmentos de DNA correspondentes aos operadores/promotores de: mercúrio (operon mer), arsênio (operon ars) e chumbo (operon pbr) para construções de biossensores bacterianos dos respectivos metais. 


\subsection{Operon mer}

A atenção voltada para o estudo dos vários temas ligados a biorremediação de íons mercúrio justifica-se pelo fato deste ser um dos metais pesados mais tóxicos para todos os seres vivos (Tabela 1$)$.

O mercúrio é um metal pesado altamente tóxico para microrganismos, mas apesar disso, ou exatamente por isso, operons de resistência a esse íon são frequentemente encontrados nos genomas microbianos (Nies, 1999; Silver e Phung, 2005). Em bactérias, a resistência aos íons mercúrio é codificada pelo operon mer que está presente em várias bactérias Gram-negativas: E. coli, Shigella flexneri, Pseudomonas aeruginosa, Xhantomonas sp., Serratia marcescens e Pseudomonas stutzeri; e também está presente em bactérias Grampositivas: Staphylococcus aureus e Bacillus sp (Nascimento et al., 1992; Nascimento e Chartone-Souza, 2003). Os operons mer variam na estrutura genética e são constituídos por genes que codificam as proteínas regulatórias (merR e merD) e estruturais de transporte (merT , merP e/ou merC , merF) e redução (merA) do íon $\mathrm{Hg}^{2+}$ a $\mathrm{Hg}^{0}$ (Figura 5). Em alguns casos, também está presente o gene mer $B$, que codifica uma proteína capaz de hidrolizar a ligação metil-mercúrio C- $\mathrm{Hg}^{2+}$, antes da redução do $\mathrm{Hg}^{2+}$ (Nascimento e Chartone-Souza, 2003; Silver et al., 2005).

O operon mer de C. metallidurans CH34 está presente no cromossomo e nos plasmídeos pMOL28 e pMOL30. No plasmídeo pMOL30 o operon mer está inserido no transposon Tn4380, sendo composto pelos genes merR, merT, merP, merA, merD e merE (Mergeay et al., 2003). No plasmídeo pMOL28, o operon mer apresenta grande homologia e a mesma disposição dos genes do operon mer do plasmídeo pMOL30, sendo também parte do transposon Tn4378 (Champier et al., 2004). No cromossomo, o operon mer é composto apenas pelos genes merR, merT, merP, merA (Mergeay et al., 2003) (Figura 6).

O principal mecanismo de resistência bacteriano ao mercúrio é a redução de íons $\mathrm{Hg}^{2+}$ a mercúrio metálico $\left(\mathrm{Hg}^{0}\right)$, que é um elemento volátil, capaz de difundir-se passivamente para o exterior da célula (Silver e Phung, 2005). O gene merP codifica uma proteína periplasmática (MerP) que é capaz de se ligar especificamente a íons $\mathrm{Hg}^{2+}$ e transportá-los à proteína de membrana MerT, cuja função é transferir o íon $\mathrm{Hg}^{2+}$ diretamente à redutase de mercúrio MerA. Íons $\mathrm{Hg}^{2+}$ que driblam esse sistema ou entram na célula por sistemas inespecíficos de captura de íons ligam-se à MerR, induzindo a expressão do operon (Figura 5) (Champier et al., 2004; Rossy et al., 2004). 


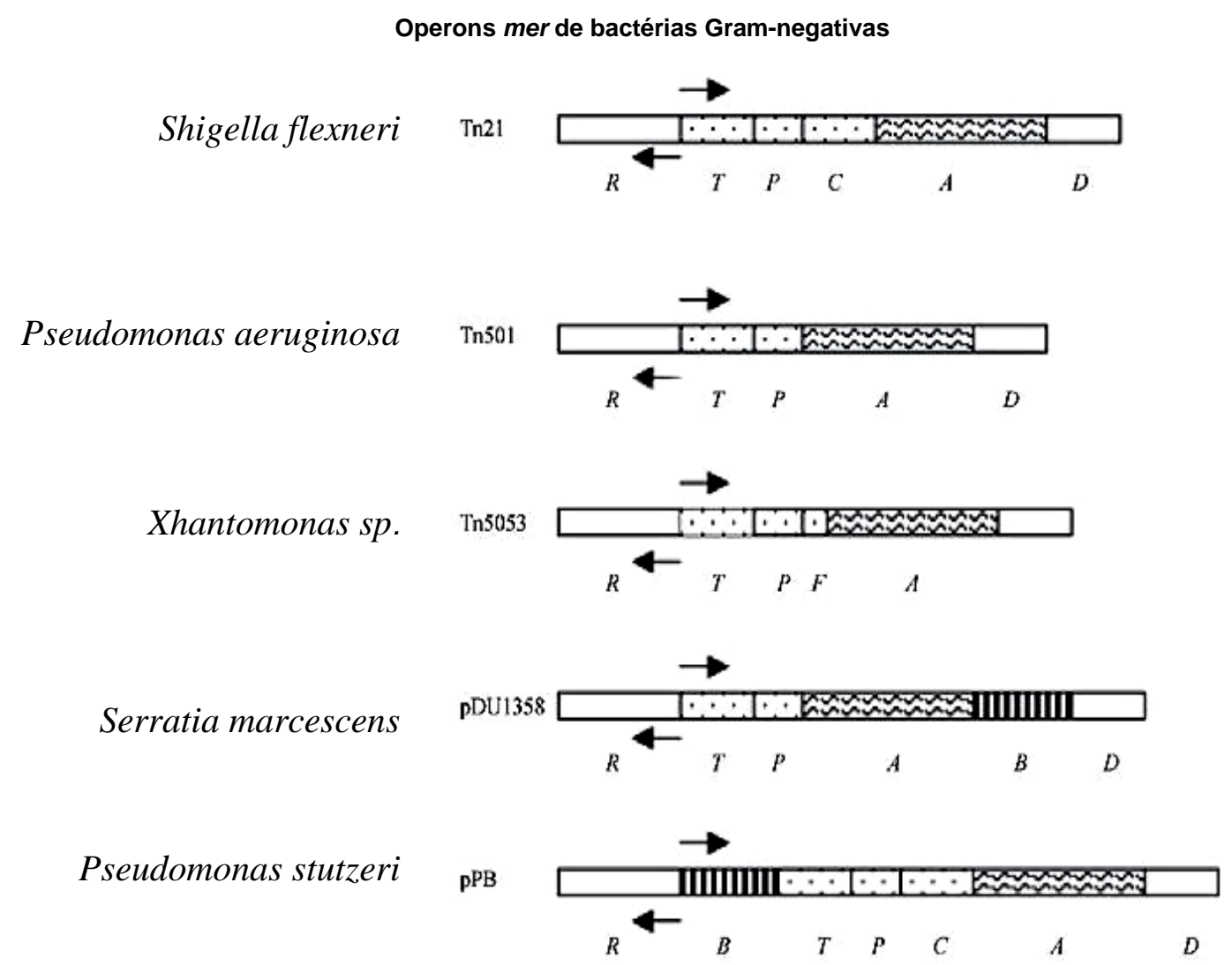

Operon mer de bactéria Gram-positiva

Staphylococcus aureus

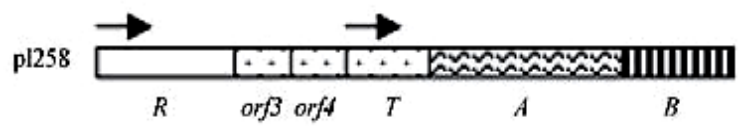

Figura 5 - Representação esquemática de operons mer de diferentes bactérias.

Fonte: Nascimento e Chartone-Souza, 2003.

A regulação da expressão do operon mer é realizada pelas proteínas MerR e MerD. MerD não se liga ao DNA, mas interage com o complexo MerR-promotor-operador, sendo um co-regulador da indução do operon. Na falta de íons $\mathrm{Hg}^{2+}$, forma-se um complexo ternário entre MerR, MerD e a região do promotor-operador, reprimindo a expressão dos genes do operon. Na presença de íons $\mathrm{Hg}^{2+}$, MerR liga-se a esse íon que é, então, deslocado da região do promotor-operador pela ação de MerD, o que permite a expressão dos genes do operon (Champier et al., 2004). 

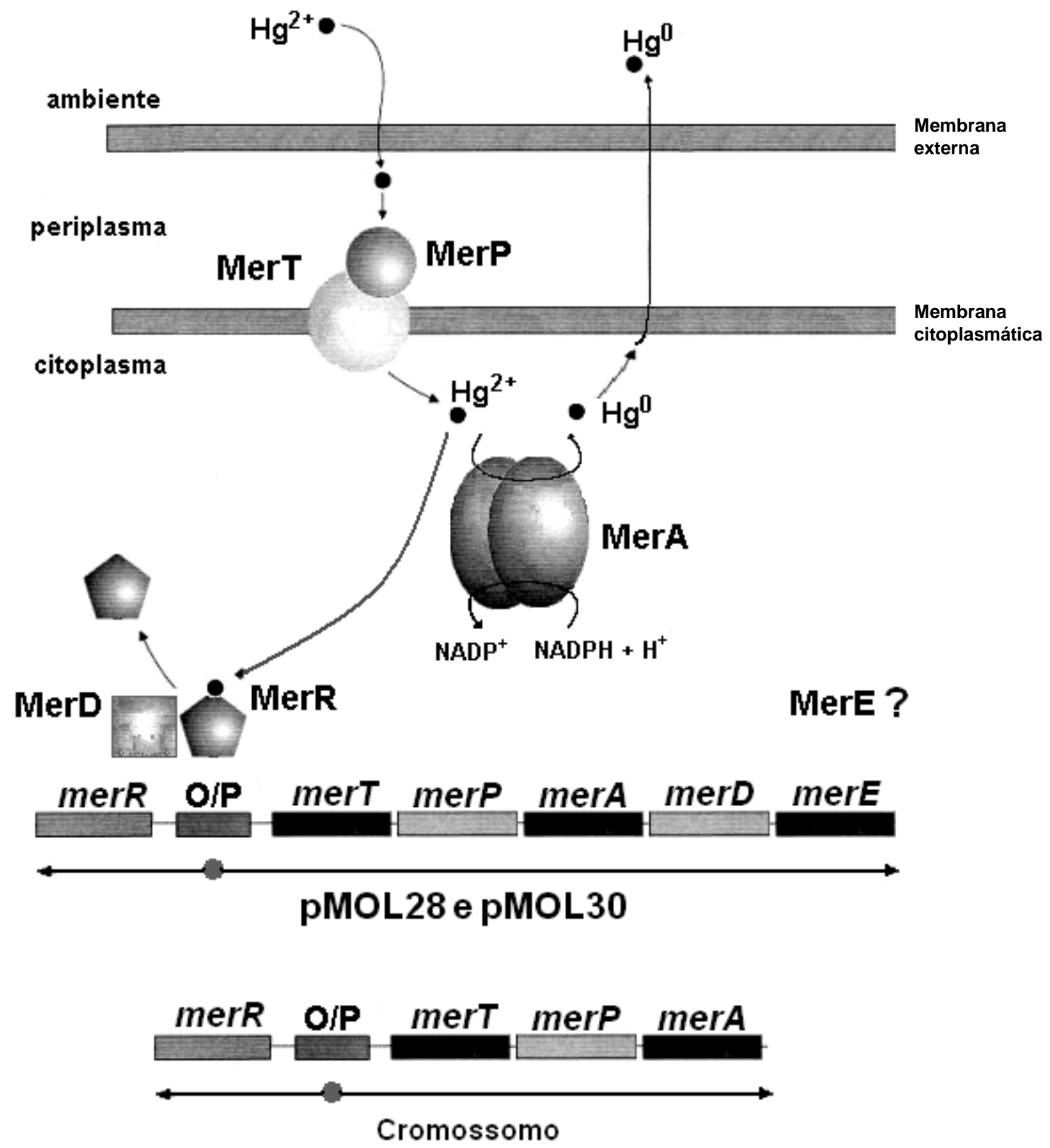

Figura 6 - Representação esquemática do sistema de resistência a $\mathrm{Hg}^{2+}$ em C. metallidurans CH34. Na parte inferior da figura estão representados os genes do operon mer presente nos plasmídeos pMOL28 e pMOL30 e na região cromossomal. As flechas indicam o sentido de transcrição dos genes. Na parte superior da figura estão indicadas as possíveis proteínas codificadas. Íons $\mathrm{Hg}^{2+}(\bullet)$ são transportados para o interior da célula pelas proteínas MerP/MerT. MerA reduz íons $\mathrm{Hg}^{2+}$ a $\mathrm{Hg}^{0}$, utilizando NADPH. O mercúrio metálico $\left(\mathrm{Hg}^{0}\right)$ é volátil e difunde-se para o meio exterior da célula. Íons $\mathrm{Hg}^{2+}$ livres ligam-se à MerR, provocando alteração da conformação MerR-MerD e consequentemente ativação do operon.

Fonte: Biondo, 2008. 
A falta do gene merD no operon mer cromossomal não impede a expressão dos genes de resistência desse operon. MerE é uma proteína com função ainda desconhecida (Silver e Phung, 2005).

Na construção da maioria das bactérias biossensoras de mercúrio foi empregado, como sensor de íons $\mathrm{Hg}^{2+}$, um fragmento de DNA contendo o gene merR e a região operadora/promotora do operon merR (Tabela 2). Todavia, mais recentemente, Omura et al. (2004) desenvolveram um biossensor bacteriano contendo um fragmento de DNA maior, correspondente ao gene merR, a região operadora/promotora e o gene merT. Estes autores relataram ter conseguido, empregando esta abordagem, obter uma bactéria biossensora muito mais sensível, capaz de detectar níveis picomolares de íons $\mathrm{Hg}^{2+}$.

Para este trabalho, a região do operon $m e r R / \mathrm{o} / \mathrm{p}$ foi inserida à montante do gene EGFP para a construção de um biossensor bacteriano específico de mercúrio.

\subsection{Operon ars}

O arsênio existe na natureza numa variedade de formas químicas, incluindo espécies orgânicas e inorgânicas. Os altos níveis de toxicidade de arsênio são muito bem conhecidos, pois os seus compostos são facilmente absorvidos por via oral ou inalação. O efeito tóxico das espécies de arsênio depende, principalmente, de sua forma química. Arsênio em águas naturais pode ocorrer como arsenito (As (III) ou $\mathrm{As}^{3+}$ ) ou arseniato (As (V) ou $\mathrm{As}^{5+}$ ). Uma longa exposição a compostos inorgânicos de arsênio pode conduzir a várias doenças. Dentre as formas mais tóxicas, o arsênio trivalente (arsenito) é 60 vezes mais tóxico que a forma oxidada pentavalente (arseniato). Os compostos inorgânicos são 100 vezes mais tóxicos que as formas orgânicas metiladas (Barra et al., 2000).

É bem conhecido que muitos microrganismos sobrevivem na presença de compostos de arsênio, induzindo a expressão de proteínas da resistência (Diorio et al., 1995).

Em E. coli K12, a presença do operon que confere resistência aos compostos derivados de arsênio, o operon ars, foi detectado pela análise do genoma (Sofia et al., 1994). O operon ars confere resistência a arseniato, arsenito e antimoniato (Carlin et al., 1995). O operon ars desta bactéria é constituído por dois genes reguladores ( $\operatorname{ars} R$ e $\operatorname{ars} D$ ) e três genes estruturais ( $\operatorname{ars} A, \operatorname{arsB}$, e $\operatorname{ars} C$ ) (Figura 7A). A proteína ArsR funciona como repressor do operon ars, ligando-se à região o/p, impedindo a transcrição dos genes à jusante. Foi demonstrado que ArsR detecta $\mathrm{As}^{3+}$ com elevada afinidade (Xu et al., 1996). Na presença de 
arsênio, ArsR sofre uma mudança conformacional e se libera da região o/p do operon, permitindo a transcrição dos genes estruturais arsDABC (Yagi, 2007).

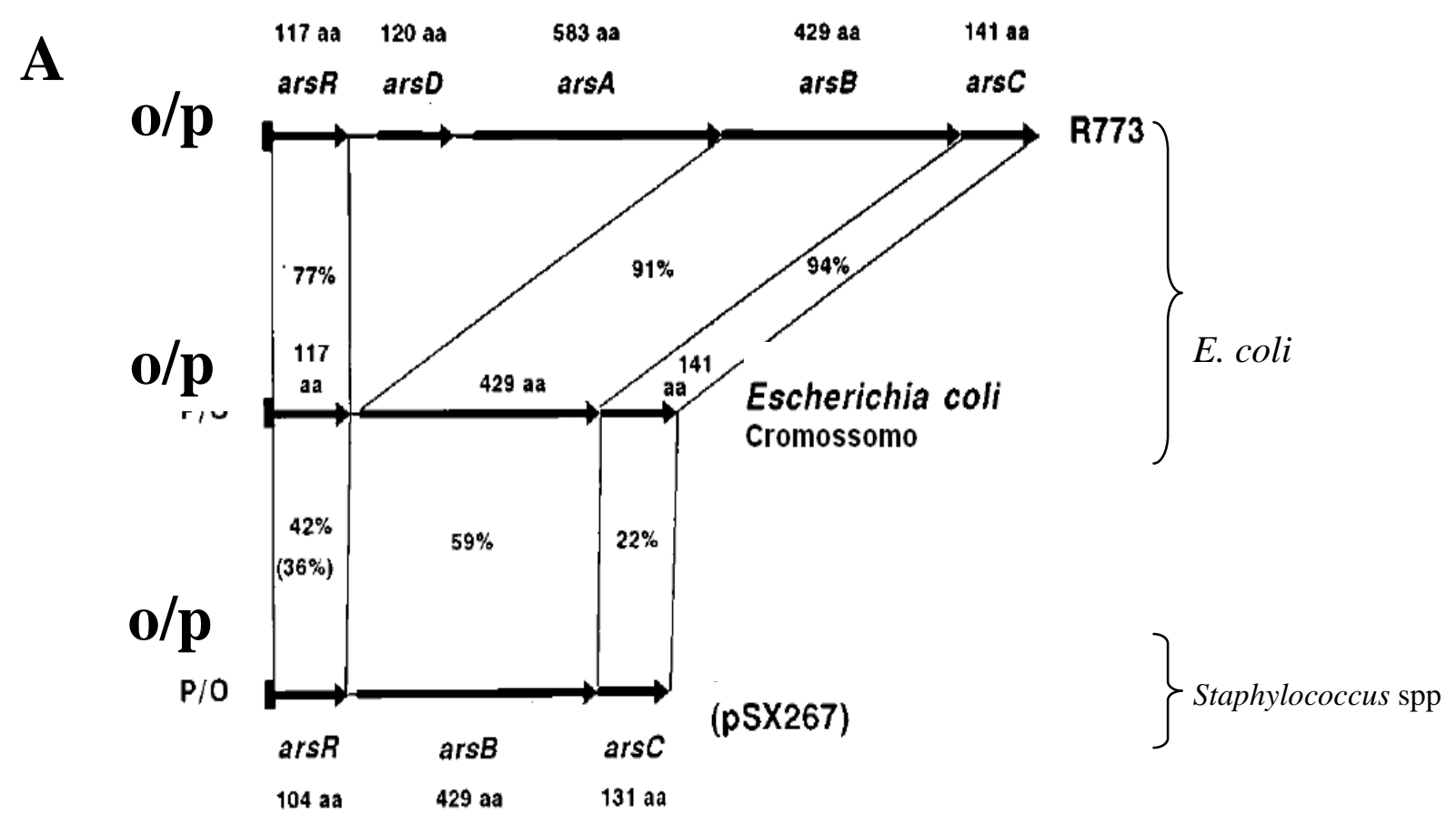

B

$\mathbf{0} / \mathbf{p}$

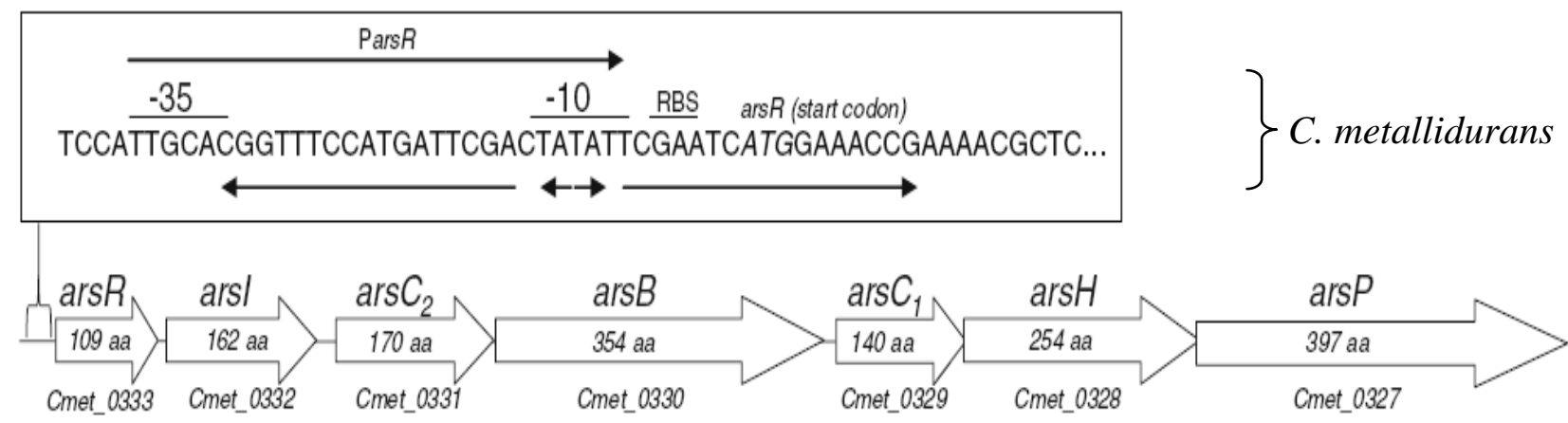

Figura 7 - Esquema da organização do operons ars de: A) E. coli: plasmídeo R773 e cromossômico de E. coli K12 e do plasmídeo pI258 de Staphylococcus spp.; B) Operon ars do cromossomo 1 de $C$. metallidurans CH34.

Fontes: A) Diorio et al., 1995; B) Zhang et al., 2009. 
O mecanismo de detoxificação de arseniato/arsenito de E. coli envolve a proteína arseniato redutase (ArsC), que converte arseniato $\mathrm{As}^{5+}$ em arsenito $\mathrm{As}^{3+}$ (mais tóxico), que é, então, bombeando para fora da célula por uma permease de arsenito (ArsB).

Recentemente, verificou-se que no genoma de C. metallidurans CH34 também há um operon de resistência a arsenito/arseniato (Zhang et al., 2009).De fato, o cromossomo 1 de $C$. metallidurans CH34 contém sete genes envolvidos na resistência a arsenito/arseniato: arsRarsI-arsC2-arsB,-arsC1-arsH-arsP (Figura 7B). Neste trabalho, a região do operon o/p/arsR foi inserida à montante do gene EGFP para a construção de um biossensor bacteriano específico de arsênio.

\subsection{Operon $p b r$}

Os autores Borremans et al. (2001) descreveram o primeiro mecanismo específico de resistência aos íons $\mathrm{Pb}^{2+}$ em bactérias. Esse mecanismo, descoberto em C. metallidurans CH34, é codificado pelo operon pbr e combina as funções envolvidas na captura, efluxo e acúmulo de íons $\mathrm{Pb}^{2+}$ (Figura 8A).

O operon pbr contém os seguintes genes estruturais: $p b r T$, que codifica uma proteína de captura de íons $\mathrm{Pb}^{2+}$; pbrA, que codifica ATPase do efluxo de $\mathrm{Pb}^{-}$; $p b r B$, que codifica uma proteína integrante da membrana de função desconhecida; e pbrC, que codifica uma proteína peptidase sinal. A jusante do $p b r C$, o gene do $p b r D$, foi identificado como uma região do DNA que seria essencial para a funcionalidade do seqüestro de íons $\mathrm{Pb}^{2+}$. A transcrição do $\operatorname{pbrABCD}$ é dependente da indução da região promotora por íons $\mathrm{Pb}^{2+}$. A regulação do operon é feita pelo gene $p b r R$, que pertence à família de proteínas regulatórias MerR sensíveis a íons (Borremans et al., 2001). A Figura 8B ilustra um esquema do operon pbr e parte da seqüência de DNA.

Outros mecanismos de resistência ao chumbo foram descritos, todavia, não específicos, tais como o operon cad $\left(\mathrm{Cd}^{2+} / \mathrm{Pb}^{2+} / \mathrm{Sb}^{3+}\right)$, encontrado no plasmídeo pI258 de $S$. aureus (Liao et al., 2006), e o gene zntA $\left(\mathrm{Cd}^{2+} / \mathrm{Zn}^{2+} / \mathrm{Pb}^{2+}\right)$ de E. coli (Shetty et al., 2003).

Para o trabalho aqui proposto foi empregada a inserção da região do operon $p b r R / \mathrm{o} / \mathrm{p}$ à montante do gene EGFP para a construção de um biossensor bacteriano específico de chumbo. 
A)

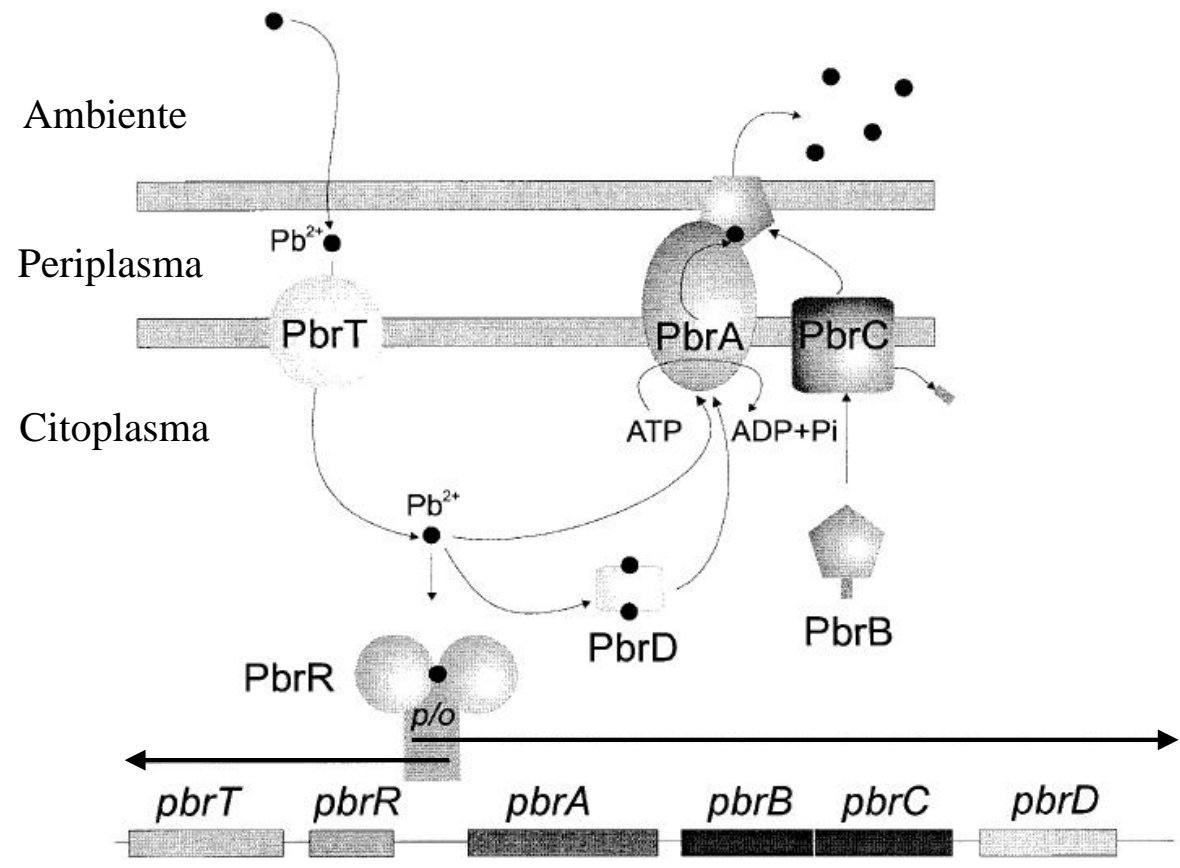

B)

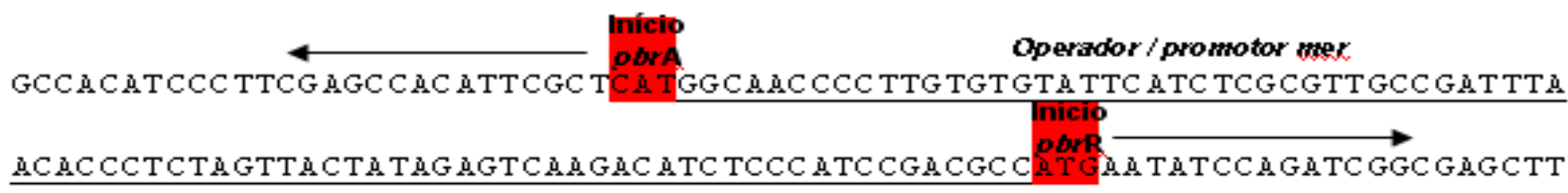

GCCA AGC GCACCGC ATGCCCGGTGGTGACCATTCGCTTCTACGÄCÄGÄGGGCTGTTGCCGCCGCCGG

GCCGCAGCCGGGGG Д̈TTTTCGCCTGTÄTGGCGAGG AGC ACG TGG AGCGCTTGCAGTTCATTCGTCACTG

CCGGTCTCTGGATATGCCGTTGAGCG ACGTACGGACCTT ATTGAGTTACCGGÄGCGGCCCGACCAGGAT

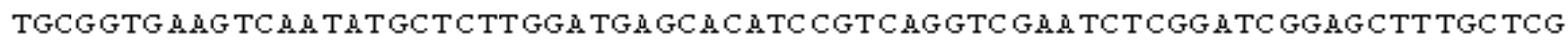

ÄCTGÄGCACCATTTGGTGGÄCTGCGCGÄGCCTGTTCTGGTGCCAGGCCCGCCC ÄTCGTGCGGGAT

TCTGCAGGGACTGTCGG ACTGCGTGTGTG ATACGCGGGGGACCACCGCCCATCC ÄGCGACTM̈RGTGGGC

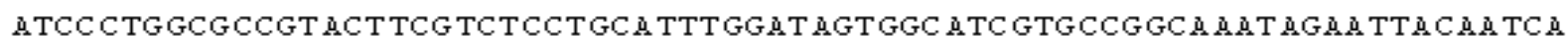

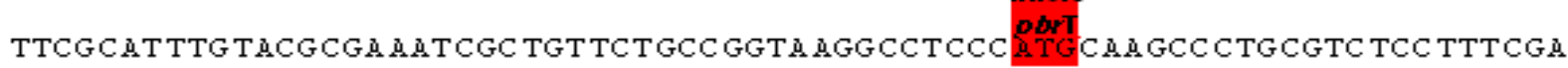

Figura 8 - A) Modelo do operon $p b r$ de $C$. metallidurans CH34 que codifica resistência aos íons $\mathrm{Pb}^{2+}$. Estão indicados os genes: $p b r T$ (captura de $\mathrm{Pb}^{2+}$ ), $p b r R$ (regulador do operon), $p b r A$ (ATPase do efluxo de $\mathrm{Pb}^{2+}$ ), $p b r B$ (função ainda desconhecida), $p b r C$ (peptidase sinal), $p b r D$ (seqüestro de $\mathrm{Pb}^{2+}$ ). B) Parte da seqüência do operon pbr do plasmídeo pMOL30 de C. metallidurans CH34, destacando o início e o fim do gene $p b r R$ e a região operadora/promotora.

Fontes: A) Borremans et al., 2001; B) National Center for Biotechnology Information (NCBI). 
Os objetivos deste trabalho foram construir, através de técnicas de engenharia genética, três biossensores bacterianos, cada um deles especificamente capaz de detectar e quantificar os metais pesados mercúrio, arsênio e chumbo. 
3 MATERIAL E MÉTODOS 


\subsection{Material Biológico}

As linhagens bacterianas que foram utilizadas neste trabalho estão descritas na Tabela 3. Os oligonucleotídeos iniciadores, empregados na técnica da Reação em Cadeia da Polimerase (PCR - "Polymerase Chain Reaction”), para amplificação dos fragmentos de DNA de interesse foram sintetizados pela empresa "Bionner Oligo Synthesis Report” e estão descritos na Tabela 4. Os plasmídeos utilizados para a obtenção das cepas recombinantes e suas características principais encontram-se apresentados na Tabela 5.

As diversas técnicas de manipulação microbiana, tais como: preparo de meios de cultura e condições de crescimento; reagentes e soluções; extração e purificação de DNA total e plasmidial, análise do DNA em gel de agarose; preparo de células bacterianas competentes; transformação de bactérias por eletroporação; foram realizadas conforme Sambrook e Russell (2001).

Tabela 3 - Linhagens bacterianas utilizadas neste trabalho

\begin{tabular}{|c|c|c|c|}
\hline Linhagem & Características genéticas & Utilização & Origem \\
\hline $\begin{array}{c}\text { C. } \\
\text { metallidurans } \\
\text { CH34 }\end{array}$ & $\begin{array}{l}\text { } \beta \text {-proteobacteria quimiolitotrófica facultativa. } \\
\text { Possui um cromossomo (3,9 Mb), um } \\
\text { megaplasmideo (2,6 Mb) e dois grandes } \\
\text { plasmídeos: pMOL30 (234 kb) e pMOL28 } \\
\text { (171 kb). Múltipla resistência a metais. }\end{array}$ & $\begin{array}{l}\text { Fonte dos } \\
\text { operons } \\
\text { mer, ars e } \\
\text { pbr }\end{array}$ & $\begin{array}{c}\text { DSMZ } \\
\left(n^{\circ} 2839\right)\end{array}$ \\
\hline E. coli DH5 $\alpha$ & 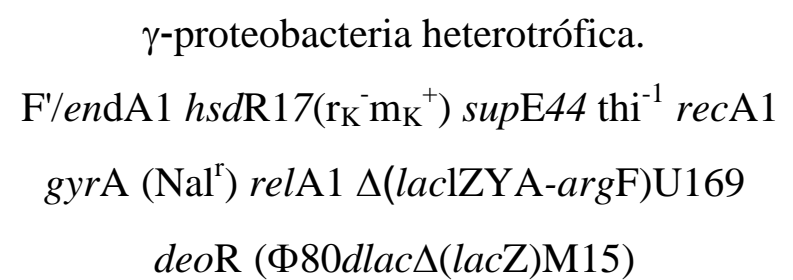 & $\begin{array}{c}\text { Inserção } \\
\text { dos } \\
\text { plasmídeos }\end{array}$ & $\begin{array}{l}\text { Coleção do } \\
\text { Laboratório }\end{array}$ \\
\hline
\end{tabular}


Tabela 4 - Sequência dos oligonucleotídeos empregados para amplificação por PCR.

\begin{tabular}{|c|c|c|c|}
\hline Nome & Sequência & $\begin{array}{c}\text { Sítio de } \\
\text { restrição }\end{array}$ & Origem \\
\hline merR-primerF: & 5’ GGATCCCTAAGGCATAGCCG 3’' & BamHI & $\begin{array}{c}\text { este } \\
\text { trabalho }\end{array}$ \\
\hline merR-primerR: & 5' GACATATGCTTGTCCTTTCGAATTG 3' & NdeI & $\begin{array}{c}\text { este } \\
\text { trabalho }\end{array}$ \\
\hline arsR-primerF: & 5’ CTGCAGGTTGAGGCCGAATT 3’ & Pstl & $\begin{array}{c}\text { este } \\
\text { trabalho }\end{array}$ \\
\hline arsR-primerR: & 5’ CATATGTCAGGACTCCGTAGC 3’ & NdeI & $\begin{array}{c}\text { este } \\
\text { trabalho }\end{array}$ \\
\hline pbrR-PrimerF: & 5’ GGATCCCTAGTCGCTTGGATG 3’' & BamHI & $\begin{array}{c}\text { este } \\
\text { trabalho }\end{array}$ \\
\hline pbrR-primerR: & 5' CTCATATGAACCCCTTGTGTGTATTC 3' & NdeI & $\begin{array}{c}\text { este } \\
\text { trabalho }\end{array}$ \\
\hline
\end{tabular}

Tabela 5 - Plasmídeos utilizados neste trabalho.

\begin{tabular}{ccc}
\hline Plasmídeo & Resistência & Origem \\
\hline pTZ57R/T & Ampicilina & Fermentas \\
pTZ-Mer & Ampicilina & este trabalho \\
pTZ-Ars & Ampicilina & este trabalho \\
pTZ-Pbr & Ampicilina & este trabalho \\
pBB-EGFP & Cloranfenicol & Quadros, 2007 \\
pGHg & Cloranfenicol & este trabalho \\
pGAs & Cloranfenicol & este trabalho \\
\hline pGPb & Cloranfenicol & este trabalho \\
\hline
\end{tabular}




\subsection{Reagentes e Soluções}

Os reagentes utilizados no preparo das soluções foram de grau de pureza analítica e a água usada foi bidestilada.

As soluções foram esterilizadas a $120^{\circ} \mathrm{C}$, durante 20 minutos ou quando necessário, foram filtradas em membrana do tipo "millipore" de poro de $0,22 \mu \mathrm{m}$.

a) Solução I: Tris-HCI 25 mM, EDTA 10 mM, Glicose 50 mM, pH 8,0

b) Solução II: NaOH 0,2 M, SDS 1\%.

c) Solução III: Acetato de Sódio 3 M, Ácido Acético 2 M, pH 4,8.

d) Solução de RNase A: $10 \mathrm{mg} / \mathrm{mL}$ em NaOH 0,1 M.

e) Solução de lise: Tris 40 mM, SDS 1\%, pH final 12,6 com NaOH 5 M.

f) Solução estoque de Brometo de Etídeo: $100 \mu \mathrm{g} / \mathrm{mL}$ de água destilada.

g) TE: Tris-HCI 20mM, EDTA $20 \mathrm{mM}$, pH final 8,0.

h) TBE 10X: Tris 0,89 mM, Ácido Bórico 0,89 mM, EDTA 0,2 mM.

i) Tampão E: Tris-acetato 40 mM, EDTA 2 mM, pH 7,9.

j) Tampão de Amostra (10X) - “Stop Mix”: glicerol 50\%, azul de bromofenol 0,5\%, EDTA $100 \mathrm{mM}, \mathrm{pH} 8,0$.

k) Solução Salina-EDTA: NaCl 150 mM, EDTA 100 mM.

l) Fenol/clorofórmio 1:1.

m) Clorofórmio/álcool isoamílico 24:1.

n) Acetato de Amônio 4 M.

o) Etanol $70 \%$.

p) $\mathrm{NaCl} 5 \mathrm{M}$.

q) SDS $20 \%$.

r) XGal (5-bromo-4-cloro-3-indol- $\beta$-D-Galactopiranosídeo) $50 \quad \mathrm{mg} / \mathrm{mL}$ de $\quad$ N,N'dimetilformamida.

s) IPTG (isopropil- $\beta$-D-tiogalactopiranosídeo) 0,1 M.

t) Fenol Tamponado.

u) Etanol.

v) Isopropanol. 


\subsection{Meios de Cultura e Condições de Crescimento Bacteriano}

Os componentes dos meios de culturas bacterianos, após o preparo, foram esterilizados em autoclave a $120^{\circ} \mathrm{C}$, por 20 minutos. Os meios sólidos empregados no cultivo foram idênticos aos meios líquidos, acrescidos de 2\% de Ágar Bacteriológico. As colônias de E. coli DH5 $\alpha$ e dos clones recombinantes derivados, quando semeados em meio sólido, contidos em placas de Petri, foram incubados em estufa, a $37^{\circ} \mathrm{C}$, enquanto as colônias de $C$. metallidurans $\mathrm{CH} 34$ foram incubadas em estufa, a $28^{\circ} \mathrm{C}$. O crescimento em meio líquido foi feito com aeração em agitador nas mesmas temperaturas citadas.

a) LB - Luria Bertani (Meio Completo para Bactérias): 1\% Triptona, 1\% Cloreto de Sódio, 0,5\% Extrato de Levedura.

b) Caldo Nutriente (Meio Completo para Bactérias): Extrato de carne 0,3\%, Peptona 0,5\%.

c) SOC (Meio de Recuperação para Bactérias): 2\% Triptona, 0,5\% Extrato de Levedura, 10 mM de Cloreto de Magnésio, 10 mM Sulfato de Magnésio, 20 mM Glicose.

d) MJS (Meio Mínimo): HEPES 12,5 mM (pH 7,1), NaCl 50 mM, NH${ }_{4} \mathrm{Cl} 20 \mathrm{mM}$, KCl 1 mM, Casamino Ácido 0,8\%, Glicerol 0,4\%, $\mathrm{MgCl}_{2} 1 \mathrm{mM}, \mathrm{CaCl}_{2}$ 0,1 mM, $\mathrm{MnCl}_{2}$ 0,05 $\mathrm{mM}$, Tiamina $0,005 \%$.

\subsection{Agentes Antimicrobianos}

Os agentes antimicrobianos foram adicionados ao meio de cultura quando necessário, nas seguintes concentrações finais:

a) Ampicilina: $100 \mu \mathrm{g} / \mathrm{mL}$

a) Carbenecilina: $60 \mu \mathrm{g} / \mathrm{mL}$.

b) Cloranfenicol: $25 \mu \mathrm{g} / \mathrm{mL}$ para E. coli e $230 \mu \mathrm{g} / \mathrm{mL}$ para C. metallidurans

\subsection{Enzimas}

As enzimas de restrição e outras enzimas utilizadas na manipulação de DNA seguiram seus respectivos protocolos e tampões, de acordo com cada fabricante. 


\subsection{Extração e purificação de DNA plasmidial de E.coli:}

\subsubsection{Minipreparação de DNA plasmidial - "MiniPrep”}

Os clones de bacterianos foram inoculados em $5 \mathrm{~mL}$ de meio $\mathrm{LB}$ contendo o antibiótico apropriado, na concentração apropriada. O inóculo foi incubado $\left(37{ }^{\circ} \mathrm{C}\right)$ por aproximadamente 16 horas, com aeração em agitador.

Uma alíqüota de $3 \mathrm{~mL}$ foi centrifugada, em tubos de microcentrífuga de 1,5 mL, a 12000 g por 2 minutos, sendo o sobrenadante descartado.

O sedimento foi ressuspenso em $300 \mu \mathrm{L}$ de Solução I, com uma micropipeta. Em seguida, foram adicionados $300 \mu \mathrm{L}$ da Solução II, mantedo-a em repouso por 5 minutos em temperatura ambiente. Após este período foram adicionados $300 \mu \mathrm{L}$ da Solução III, sendo então incubada durante 10 minutos no gelo. Após esse tempo os tubos foram centrifugados a 12000 g, por 15 minutos, à $4{ }^{\circ} \mathrm{C}$. O sobrenadante foi recuperado e a este foram acrescentados $1 \%$ de Solução de RNase A, realizando-se uma incubação em banho-maria $\left(37^{\circ} \mathrm{C}\right)$, por 30 minutos. Logo em seguida, adicionou-se $600 \mu \mathrm{L}$ de solução clorofórmio/álcool isoamílico; a mistura foi homogeneizada por inversão e centrifugada a 12000 g, por 2 minutos, em temperatura ambiente. A fase aquosa foi recuperada e a esta, acrescentada $750 \mu \mathrm{L}$ de isopropanol. A solução foi misturada por inversão e incubada por 30 minutos, em temperatura ambiente.

Após esse tempo a solução foi centrifugada a 12000 g, por 15 minutos, à $4{ }^{\circ} \mathrm{C}$, o sedimento foi lavado com etanol $70 \%\left(4{ }^{\circ} \mathrm{C}\right)$ e seco a vácuo durante 20 minutos. O resíduo seco foi ressuspenso em $50 \mu \mathrm{L}$ de água destilada. Uma alíquota deste material foi, então, submetida à eletroforese em gel de agarose.

\subsubsection{Maxipreparação de DNA plasmidial - “Maxi Prep”}

Uma cultura bacteriana de $5 \mathrm{~mL}$ pré-crescida foi inoculada em $300 \mathrm{~mL}$ de meio líquido contendo o antibiótico apropriado, na concentração apropriada. O inóculo foi incubado $\left(37^{\circ} \mathrm{C}\right)$ por aproximadamente 16 horas, com aeração em agitador.

A cultura foi centrifugada a $6000 \mathrm{~g}$, por 10 minutos, à $4{ }^{\circ} \mathrm{C}$, sendo o sobrenadante descartado. 
O sedimento foi ressuspenso em 4 mL de Solução I, com uma pipeta. Em seguida, foram adicionados $8 \mathrm{~mL}$ da Solução II. Após homogeneização, incubou-se por 10 minutos, em temperatura ambiente. Após este período, foram adicionados $6 \mathrm{~mL}$ da Solução III, com incubação durante 15 minutos no gelo. Após estes passos, a suspensão foi centrifugada a $12000 \mathrm{~g}$, por 15 minutos, à $4{ }^{\circ} \mathrm{C}$. O sobrenadante foi recuperado e a este acrescentado 1 volume de isopropanol. Foi realizada a incubação em temperatura ambiente, por 10 minutos, seguida de centrifugação a 12000 g, por 15 minutos, à $4{ }^{\circ} \mathrm{C}$. O precipitado foi ressuspenso em $2 \mathrm{~mL}$ de TE. Foram feitas alíquotas de $1 \mathrm{~mL}$ para cada microtubo. Logo em seguida, adicionou-se $500 \mu \mathrm{L}$ fenol tamponado, homogeneizando manualmente, por 3 minutos. Centrifugou-se a $12000 \mathrm{~g}$, por 15 minutos, à $4{ }^{\circ} \mathrm{C}$. A fase aquosa (superior) foi transferida para outro microtubo e foram adicionados $500 \mu \mathrm{L}$ de solução clorofórmio/álcool isoamílico. A mistura foi homogeneizada por inversão e centrifugada a $12000 \mathrm{~g}$, por 5 minutos, à $4{ }^{\circ} \mathrm{C}$. A fase aquosa (superior) foi então recuperada e repetida à última etapa da extração, com o clorofórmio/álcool isoamílico. Foram feitas alíquotas de $500 \mu \mathrm{L}$ com a fase aquosa recuperada, que foram acondicionadas em diferentes microtubos. Para a precipitação do DNA plasmidial, foram acrescentados $50 \mu \mathrm{L}$ de acetato de amônio $4 \mathrm{M}$ e $1 \mathrm{~mL}$ de etanol e incubação $\left(4^{\circ} \mathrm{C}\right)$, por 1 hora. Após esse tempo, a solução foi centrifugada a $12000 \mathrm{~g}$, por 15 minutos, à $4{ }^{\circ} \mathrm{C}$. O sedimento foi lavado com etanol $70 \%\left(4{ }^{\circ} \mathrm{C}\right)$ e seco a vácuo, durante 20 minutos. O resíduo seco foi ressuspenso em $100 \mu \mathrm{L}$ de água destilada. Adicionou-se $1 \mu \mathrm{L}$ de RNase A e incubou-se por 30 minutos $\left(37^{\circ} \mathrm{C}\right)$. Em seguida, repetiu-se a etapa de precipitação do DNA plasmidial. Uma alíquota deste material foi então submetida à eletroforese em gel de agarose.

\subsection{Isolamento e manipulação de megaplasmídeo}

Foi realizado o cultivo de C. metallidurans CH34 de 15 mL em Caldo Nutriente, que foi incubada $\left(28{ }^{\circ} \mathrm{C}\right)$ por 16 horas com aeração em agitador. A cultura foi centrifugada a $12000 \mathrm{~g}$, por 15 minutos, à $4{ }^{\circ} \mathrm{C}$. O precipitado foi ressuspenso em $1 \mathrm{~mL}$ do Tampão E, acrescido de $2 \mathrm{~mL}$ da solução de lise recentemente preparada. A mistura foi incubada em temperatura ambiente, por 20 minutos, sob agitação suave. Incubou-se, subseqüentemente, à $68{ }^{\circ} \mathrm{C}$, por 75 minutos. A esta suspensão, adicionou-se $0,5 \mathrm{~mL}$ de $\mathrm{NaCl} 4 \mathrm{M}$ e $8 \mathrm{~mL}$ de fenolclorofórmio (1:1, saturado em $\left.\mathrm{H}_{2} \mathrm{O}, \mathrm{pH} 4,8\right)$ e misturou-se, delicadamente, por 30 minutos, em temperatura ambiente. Em seguida, o material foi centrifugado a 12000 g, por 30 minutos, 
à $4{ }^{\circ} \mathrm{C}$ e armazenado por 2 horas, à $4{ }^{\circ} \mathrm{C}$. A fase aquosa foi transferida para outro tubo, onde foram adicionados com $2 \mathrm{~mL}$ de éter dietílico. Novamente, a preparação foi centrifugada em rotação de $12000 \mathrm{~g}$, por 5 minutos, à $4{ }^{\circ} \mathrm{C}$. Descartou-se a fase superior e o éter dietílico residual foi evaporado por aproximadamente 20 minutos, à $37{ }^{\circ} \mathrm{C}$. Foram feitas alíquotas de $750 \mu \mathrm{L}$ da solução de DNA e, em cada uma delas, acrescentado $750 \mu \mathrm{L}$ de isopropanol. A preparação foi misturada por inversão e incubada por 30 minutos em temperatura ambiente. Após esse tempo de incubação a solução foi centrifugada a 12000 g, por 15 minutos, à $4{ }^{\circ} \mathrm{C}$. O sedimento foi lavado com etanol $70 \%\left(4{ }^{\circ} \mathrm{C}\right)$ e seco a vácuo durante 20 minutos. O resíduo seco foi ressuspenso em $100 \mu \mathrm{L}$ de água destilada.

\subsection{Análise do DNA em gel de agarose}

As análises dos DNAs em géis de agarose foram feitas quando se desejavam visualizar os plasmídeos digeridos com enzimas de restrição e em experimentos de purificação de fragmentos de DNA. O gel de agarose $0,8 \%$ foi preparado com tampão TBE na concentração final de 0,5X, e $0,5 \mu \mathrm{g} / \mathrm{mL}$ de brometo de etídeo.

As amostras dos DNAs, misturadas a $20 \%$ de solução de tampão de amostra, foram aplicadas em gel e, em seguida, a eletroforese foi realizada em tampão de corrida TBE 0,5X, conforme descrito em Sambrook et al., (2001). Para a visualização do DNA foi utilizado o transluminador com luz ultravioleta de $254 \mathrm{~nm}$. Para a fotodocumentação dos géis, foi utilizado o aparelho "Eagle-eye" da "Stratagene".

\subsection{Purificação de fragmentos de DNA em gel de agarose}

Para este procedimento foi utilizado o "Wizard SV Gel and PCR Clean-Up System” (Promega).

Após a eletroforese em gel de agarose, a banda correspondente ao fragmento de DNA de interesse foi cortada do gel e transferida para um microtubo. Adicionou-se 1 volume de tampão de ligação. O gel foi fundido em banho-maria $\left(65^{\circ} \mathrm{C}\right)$. Após a fusão, o material foi transferido para minicoluna, encaixada a um microtubo de $2 \mathrm{~mL}$. O conjunto foi incubado por 1 minuto, em temperatura ambiente e, em seguida, centrifugado a 12000 g. O líquido do tubo foi descartado. Foram adicionados $700 \mu \mathrm{L}$ da solução de lavagem. Novamente o material foi incubado, por 1 minuto, em temperatura ambiente e, em seguida, centrifugado a 12000 g. O 
líquido do tubo foi descartado. Repetiu-se o procedimento de lavagem com $500 \mu \mathrm{L}$ da mesma solução. Seguiu-se uma centrifugação de 5 minutos, a 12000 g em temperatura ambiente. O microtubo de $2 \mathrm{~mL}$ foi descartado e a minicoluna foi inserida em um novo microtudo de 1,5 $\mathrm{mL}$. Acrescentou-se $50 \mu \mathrm{L}$ de água estéril à minicoluna, incubou-se por 5 minutos e novamente centrifugou-se a 12000 g, por 2 minutos, em temperatura ambiente. Descartou-se a minicoluna. O microtubo contendo o DNA purificado foi estocado à $-20^{\circ} \mathrm{C}$.

\subsection{Ligação de fragmentos de DNA}

As concentrações de DNA (vetor:inserto) utilizadas nos sistemas de ligação variaram de acordo com o experimento a ser executado. Normalmente, a quantidade de inserto foi de duas a três vezes a superior de vetor, considerando-se o número de moléculas.

O seguinte sistema de ligação foi montado: $5 \mu \mathrm{L}$ das soluções contendo DNAs a serem ligados (vetor + inserto), 1/10 do volume final de tampão de ligase $10 \mathrm{X}, 0,5 \mu \mathrm{L}$ da enzima DNA ligase do Fago T4 e água bidestilada estéril para completar o volume desejado. Tipicamente, o volume final foi de $15 \mu \mathrm{L}$, podendo variar de 15 a $20 \mu \mathrm{L}$. Os sistemas foram incubados à $16^{\circ} \mathrm{C}$, por 16 - 24 horas.

\subsection{Preparo de células bacterianas competentes}

Uma cultura de $5 \mathrm{~mL}$ de E. coli DH5 $\alpha$ pré-crescida foi inoculada em $500 \mathrm{~mL}$ de meio líquido LB e incubada $\left(37^{\circ} \mathrm{C}\right)$, com agitação, até ter atingido uma absorbância de em torno de 0,5 (sob um densidade ótica de $600 \mathrm{~nm}$ ). A suspensão foi então coletada em tubos de centrífuga de $500 \mathrm{~mL}$, deixada em repouso no gelo por cerca de 30 minutos e centrifugada a $6000 \mathrm{~g}$, por $15 \mathrm{~min}$, à $4^{\circ} \mathrm{C}$. O sobrenadante foi removido e o sedimento ressuspenso em 500 $\mathrm{mL}$ de água destilada estéril gelada. As células foram novamente centrifugadas, como no item anterior. Após a centrifugação, as células foram ressuspensas em $250 \mathrm{~mL}$ de água gelada destilada estéril e centrifugada novamente. As células foram ressuspensas em $50 \mathrm{~mL}$ de uma solução de glicerol $10 \%$, à $4{ }^{\circ} \mathrm{C}$, e centrifugadas pela última vez. As células foram ressuspensas em $1 \mathrm{~mL}$ de glicerol $10 \%$, à $4{ }^{\circ} \mathrm{C}$. Foram feitas alíquotas de $40 \mu \mathrm{L}$ da suspensão de células em microtubos e armazenadas à temperatura de $-70^{\circ} \mathrm{C}$. 


\subsection{Transformação de bactérias por eletroporação}

As células competentes foram retiradas do freezer $-70{ }^{\circ} \mathrm{C}$ e colocadas imediatamente no gelo. Foram acrescentados cerca de 1-2 $\mu \mathrm{L}$ de DNA plasmidial. O aparelho eletroporador Gene Pulser (Bio-Rad) foi calibrado para aplicação de pulso de 2,5 V, resistência de $200 \Omega$ e capacitância de $25 \mu \mathrm{FD}$. A mistura célula/DNA foi transferida para a cubeta gelada. Em seguida o pulso foi aplicado. As cubetas foram imediatamente removidas da câmara de aplicação do pulso e foi adicionado $1 \mathrm{~mL}$ do meio SOC às células. A suspensão foi então transferida para um tubo de ensaio e incubada ( $37^{\circ} \mathrm{C}$, com agitação, por 1 hora). Após esse tempo de incubação a suspensão foi semeada em placa contendo meio LB sólido, acrescido de antibiótico apropriado e incubada em estufa $\left(37^{\circ} \mathrm{C}\right.$, por 16 horas).

Quando o plasmídeo empregado era do tipo “bluescript”, após a transformação, as células foram semeadas em meio LB sólido, acrescidos de XGal, IPTG e antibiótico apropriado e incubadas $\left(37^{\circ} \mathrm{C}\right.$, por 16 horas). Foi realizada a contagem do número de transformantes contendo o inserto (colônias brancas) e do número total de colônias (brancas e azuis).

\subsection{Amplificação de fragmentos de DNA por PCR}

Os fragmentos merR/o/p, o/p/arsR e $p b r R / \mathrm{o} / \mathrm{p}$ foram amplificados do DNA total de $C$. metallidurans CH34 pela técnica da reação em cadeia da polimerase (PCR). Estes fragmentos foram obtidos utilizando um Termociclador MJ Research PTC-200.

Misturas contendo $50 \mathrm{ng}$ de DNA genômico foram empregadas (DNA molde), $40 \mu \mathrm{M}$ de dNTPs, 10 pM de cada iniciador, 3,5 mM de $\mathrm{MgCl}$, 0,5 U de Taq DNA polimerase num volume final de $50 \mu \mathrm{L}$.

As condições de amplificação foram: a) aquecimento à temperatura de $94{ }^{\circ} \mathrm{C}$, por 2 minutos; b) desnaturação do DNA, à $94{ }^{\circ} \mathrm{C}$, por 1:30 minutos; c) anelamento dos iniciadores, à $60^{\circ} \mathrm{C}$, por 2 minutos; d) extensão do DNA, à $72{ }^{\circ} \mathrm{C}$, por $1: 30$ minutos; e) repetição de 30 ciclos (das etapas b, c, d); f) extensão final do DNA, à $72{ }^{\circ} \mathrm{C}$, por 10 minutos, para amplificação completa dos produtos. Estes fragmentos de DNA foram submetidos à eletroforese em gel de agarose. Os produtos amplificados pela PCR, foram posteriormente clonados no vetor $\mathrm{pTZ}$ 57R/T. 


\subsection{Avaliação biológica das bactérias recombinantes com os metais pesados}

As bactérias recombinantes C. metallidurans CH34 / pGHg, E. coli DH5a / pGHg, C. metallidurans CH34 / pGAs, E. coli DH5a / pGAs, C. metallidurans CH34 / pGPb e E. coli DH5 $\alpha$ / pGPb foram pré-inoculadas em Caldo Nutriente, contendo cloranfenicol, e cultivadas sob agitação, por 16 horas, à $37{ }^{\circ} \mathrm{C}$ e $28{ }^{\circ} \mathrm{C}$. A partir deste ponto foram preparadas diluições de acordo com as descrições a seguir:

\subsubsection{Mercúrio}

- $\quad$ C. metallidurans CH34 / pGHg:

- 20 tubos de ensaios contendo: Água bidestilada, inóculo da cultura na diluição1/100 do volume. Cada tubo de ensaio $\mathrm{HgCl}_{2}$, partindo do $1^{\circ}$ tubo com a concentração de $80 \mu \mathrm{M}$ e os tubos seguintes com diluições $1 / 2$ do volume, sendo zero a concentração do $20^{\circ}$ tubo.

- 20 tubos de ensaios contendo: Caldo Nutriente, inóculo da cultura na diluição1/100 do volume e cloranfenicol. A diluição do $\mathrm{HgCl}_{2}$ partiu do $1^{\circ}$ tubo com a concentração de 80 $\mu \mathrm{M}$ e os tubos seguintes com diluições $1 / 2$ do volume, sendo zero a concentração do $20^{\circ}$ tubo.

- $\quad$ E. coli DH5a / pGHg:

- 20 tubos de ensaios contendo: Água bidestilada, inóculo da cultura na diluição1/100 do volume. Cada tubo de ensaio $\mathrm{HgCl}_{2}$, partindo do $1^{\circ}$ tubo com a concentração de $625 \mathrm{nM}$ e os tubos seguintes com diluições $1 / 2$ do volume, sendo zero a concentração do $20^{\circ}$ tubo.

- 20 tubos de ensaios contendo: Caldo Nutriente, inóculo da cultura na diluição1/100 do volume e cloranfenicol. A diluição do $\mathrm{HgCl}_{2}$ partiu do $1^{\circ}$ tubo com a concentração de 20 $\mu \mathrm{M}$ e os tubos seguintes com diluições $1 / 2$ do volume, sendo zero a concentração do $20^{\circ}$ tubo.

\subsubsection{Arsênio}

- C. metallidurans CH34 / pGAs:

- 20 tubos de ensaios contendo: Água bidestilada, inóculo da cultura na diluição1/100 do volume. A diluição do $\mathrm{Na}_{2} \mathrm{HAsO}_{4} \cdot 7 \mathrm{H}_{2} \mathrm{O}$ partiu do $1^{\circ}$ tubo com a concentração de 400 $\mathrm{mM}$ e os tubos seguintes com diluições $1 / 2$ do volume, sendo zero a concentração do $20^{\circ}$ tubo. 
- 20 tubos de ensaios contendo: Caldo Nutriente, inóculo da cultura na diluição1/100 do volume e cloranfenicol. A diluição do $\mathrm{Na}_{2} \mathrm{HAsO}_{4} \cdot 7 \mathrm{H}_{2} \mathrm{O}$ partiu do $1^{\mathrm{o}}$ tubo com a concentração de $400 \mathrm{mM}$ e os tubos seguintes com diluições $1 / 2$ do volume, sendo zero a concentração do $20^{\circ}$ tubo.

- E. coli DH5a / pGAs:

- 20 tubos de ensaios contendo: Água bidestilada, inóculo da cultura na diluição1/100 do volume. A diluição do $\mathrm{Na}_{2} \mathrm{HAsO}_{4} \cdot 7 \mathrm{H}_{2} \mathrm{O}$ partiu do $1^{\circ}$ tubo com a concentração de $50 \mathrm{mM}$ e os tubos seguintes com diluições $1 / 2$ do volume, sendo zero a concentração do $20^{\circ}$ tubo.

- 20 tubos de ensaios contendo: Caldo Nutriente, inóculo da cultura na diluição1/100 do volume e cloranfenicol. A diluição do $\mathrm{Na}_{2} \mathrm{HAsO}_{4} \cdot 7 \mathrm{H}_{2} \mathrm{O}$ partiu do $1^{\mathrm{o}}$ tubo com a concentração de $50 \mathrm{mM}$ e os tubos seguintes com diluições $1 / 2$ do volume, sendo zero a concentração do $20^{\circ}$ tubo.

\subsubsection{Chumbo}

- C. metallidurans CH34 / pGPb:

- 20 tubos de ensaios contendo: Água bidestilada, inóculo da cultura na diluição1/100 do volume. A diluição do $\mathrm{Pb}\left(\mathrm{NO}_{3}\right)_{2}$ partiu do $1^{\circ}$ tubo com a concentração de $5000 \mu \mathrm{M}$ e os tubos seguintes com diluições $1 / 2$ do volume, sendo zero a concentração do $20^{\circ}$ tubo.

- 20 tubos de ensaios contendo: Caldo Nutriente, inóculo da cultura na diluição1/100 do volume e cloranfenicol. A diluição do $\mathrm{Pb}\left(\mathrm{NO}_{3}\right)_{2}$ partiu do $1^{\circ}$ tubo com a concentração de $5000 \mu \mathrm{M}$ e os tubos seguintes com diluições 1/2 do volume, sendo zero a concentração do $20^{\circ}$ tubo.

- $\quad$ E. coli DH5a / pGPb:

- 20 tubos de ensaios contendo: Água bidestilada, inóculo da cultura na diluição1/100 do volume. A diluição do $\mathrm{Pb}\left(\mathrm{NO}_{3}\right)_{2}$ partiu do $1^{\circ}$ tubo com a concentração de $625 \mu \mathrm{M}$ e os tubos seguintes com diluições $1 / 2$ do volume, sendo zero a concentração do $20^{\circ}$ tubo.

- 20 tubos de ensaios contendo: Caldo Nutriente, inóculo da cultura na diluição1/100 do volume e cloranfenicol. A diluição do $\mathrm{Pb}\left(\mathrm{NO}_{3}\right)_{2}$ partiu do $1^{\circ}$ tubo com a concentração de $625 \mu \mathrm{M}$ e os tubos seguintes com diluições 1/2 do volume, sendo zero a concentração do $20^{\circ}$ tubo. 
Todos os ensaios de avaliação biológica das bactérias recombinantes com os metais pesados foram feitos em triplicata.

\subsection{Microscopia de Fluorescência}

As células bacterianas foram observadas num microscópio Leica DMLB, equipado com filtro triplo (B/G/R, $n^{0}$. 513836), com aumentos de 100X e 1000X. A fonte de excitação foi uma lâmpada de vapor de mercúrio. O microscópio estava acoplado a uma câmera CCD Hitachi KP-D581, para a foto-documentação das células.

\subsection{Citometria de Fluxo}

Para quantificar os níveis de fluorescência dos clones bacterianos recombinantes obtidos na presença de mercúrio, arsênio e chumbo foi utilizado o citômetro de fluxo Millipore - Guava ${ }^{\circledR}$ EasyCyte ${ }^{\mathrm{TM}}$ Mini. Os seguintes parâmetros foram utilizados:

- FSC Gain: X32

- FSC Fine Gain: $168 \%$

- SSC: $889 \mathrm{~V}$

- GRN: $937 \mathrm{~V}$

- YLW: $442 \mathrm{~V}$

- RED: $470 \mathrm{~V}$

- Flow Rate: Medium - 0,59 $\mu \mathrm{L} / \mathrm{s}$

- Refresh Rate: 1000 events

- Events Acquired: 5000

- Diluction Factor: 1

- Original volume: $10 \mathrm{~mL}$ 
4 RESULTADOS 
Para atingir os objetivos propostos, foram necessários a obtenção dos fragmentos de DNAs correnpondentes das regiões reguladoras-operadoras-promotoras (ROP) dos operons mer, ars, e pbr. Para a obtenção dos plasmídeos biossensores os fragmentos ROP e foram inseridos a montante do gene EGFP do plasmídeo pBB-EGFP. As etapas estão detalhadas a seguir.

\subsection{Biossensor de Mercúrio.}

\subsubsection{Construção do plasmídeo pGHg - Biossensor de $\mathrm{Hg}^{2+}$}

As etapas da construção do plasmídeo biossensor de $\mathrm{Hg}^{2+}$ estão esquematizadas nas figuras 9 e 10 .

O fragmento de DNA correspondente ao gene merR/OP foi amplificado por PCR, empregando o DNA total de C. metallidurans CH34, como molde e os oligonucleotídios iniciadores (“primers”) merR-primerF (com o sítio da enzima BamHI): e merR-primerR (com o sítio NdeI) (Tabela 4).

O fragmento de DNA obtido foi ligado ao vetor pTZ57R/T, dando origem ao vetor pTZ-Mer (Figura 9A). A mistura de ligação foi empregada na transformação genética, por eletroporação, de células E. coli DH5 $\alpha$.

Algumas colônias bacterianas, resistentes à ampicilina e escolhidas ao acaso, tiveram seus DNAs plasmidiais isolados, purificados e digeridos com NdeI. Os plasmídeos extraídos de dois clones recombinantes que se encaixavam aos perfis desejados foram selecionados para análises mais detalhadas. Estes plasmídeos recombinantes foram digeridos com as enzimas de restrição NdeI, BamHI e analisados em gel de agarose submetido a eletroforese, confirmandose a construção do plasmídeo desejado pTZ-Mer (Figura 9B).

Os plasmídeos pBB-EGFP e pTZ-Mer foram, primeiramente, digeridos com as enzimas NdeI e BamHI e previamente purificados. Em seguida foi realizada um mistura de ligação, utilizando a enzima T4 DNA ligase, do fragmento Mer obtido (Figura 10A) e vetor pBB-EGFP digerido (Figura 10B). 
A)
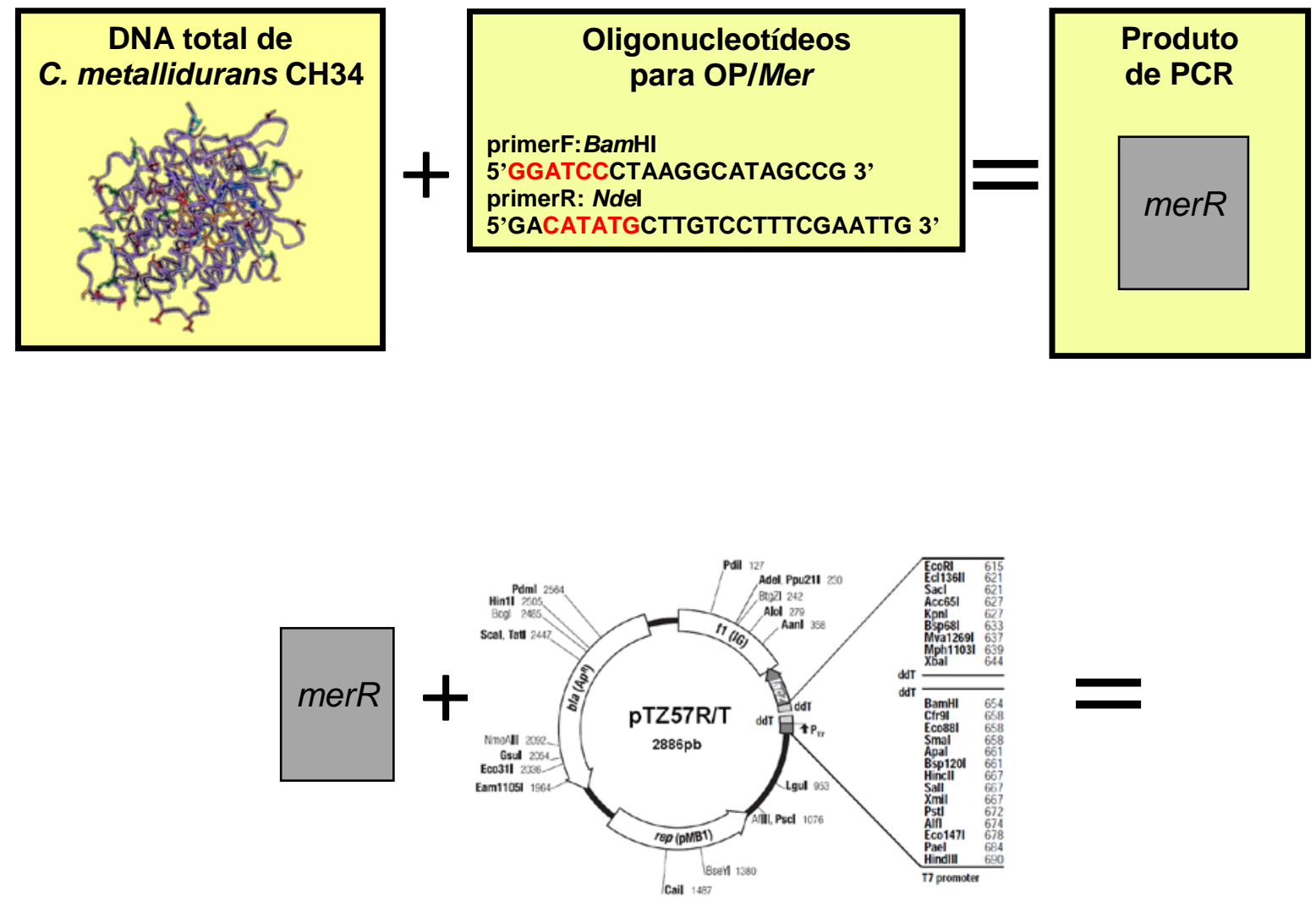

B)
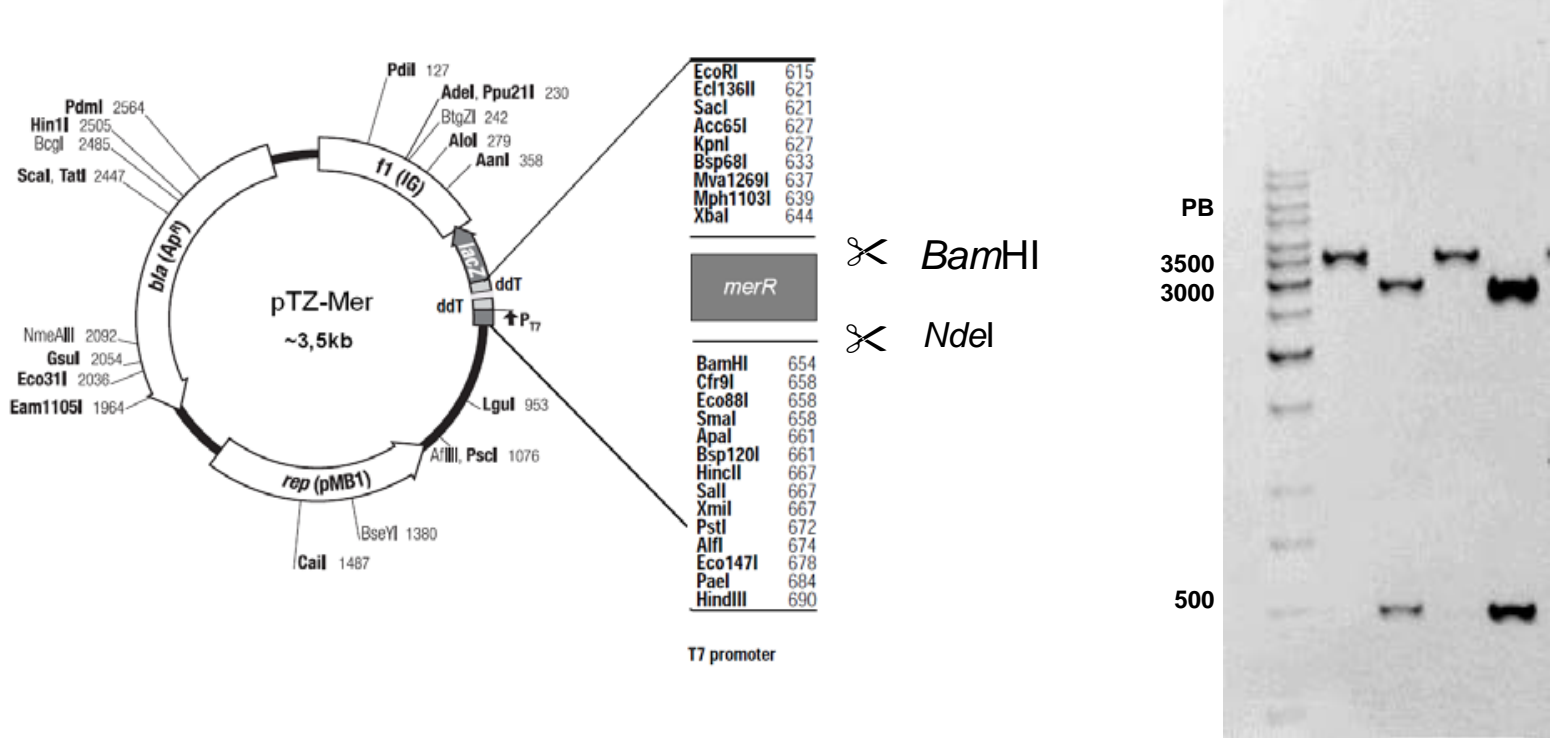

Figura 9 - A) Esquema da construção do plasmídeo pTZ-Mer; B) Perfis de migração dos fragmentos de DNA analisados em gel de agarose $0,8 \%$, corado com brometo de etídio, submetido à corrida eletroforética, onde, 1: Marcador de tamanho molecular - Ladder 1kb 50ng/ $\mu \mathrm{L}$ (Fermentas); 2 e 4 : pTZ-Mer digerido com NdeI; 3 e 5: pTZ-Mer digerido com NdeI e XhoI. 
A)
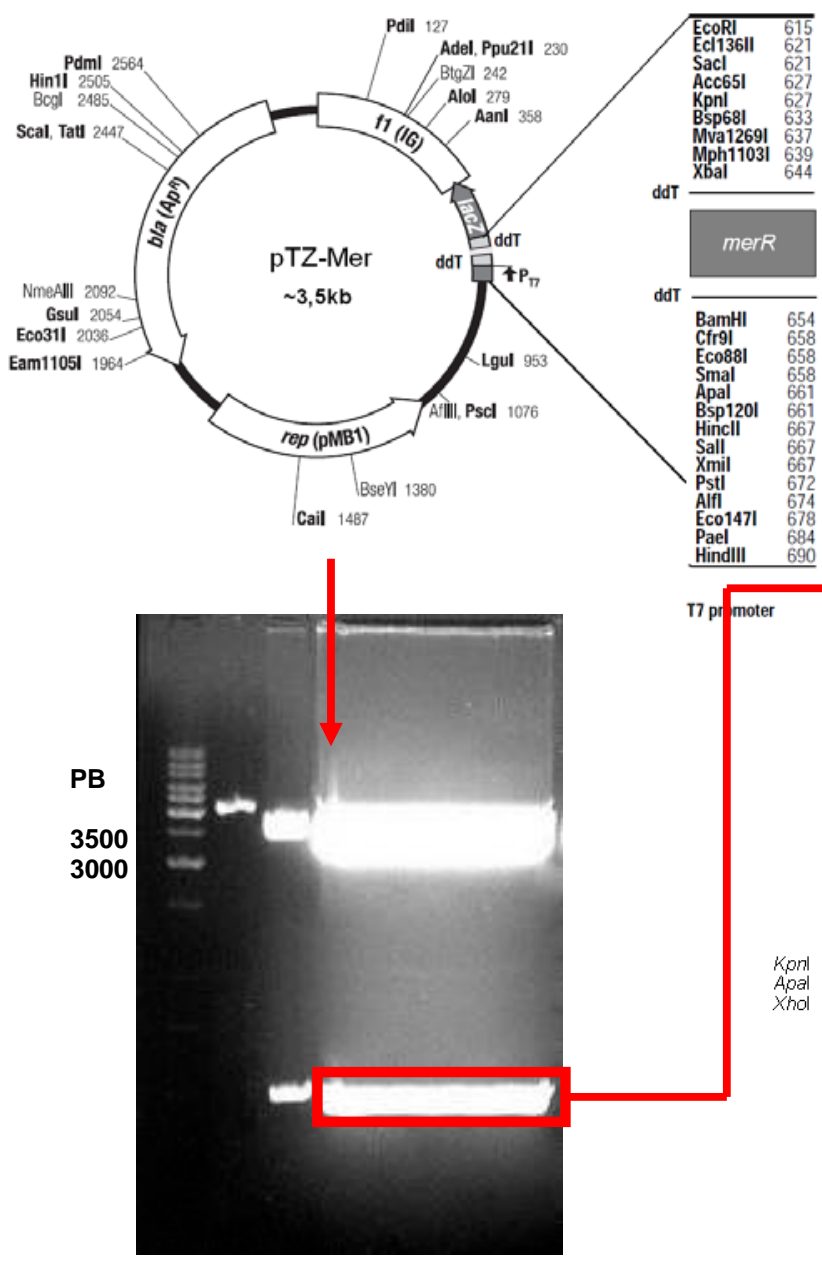

B)
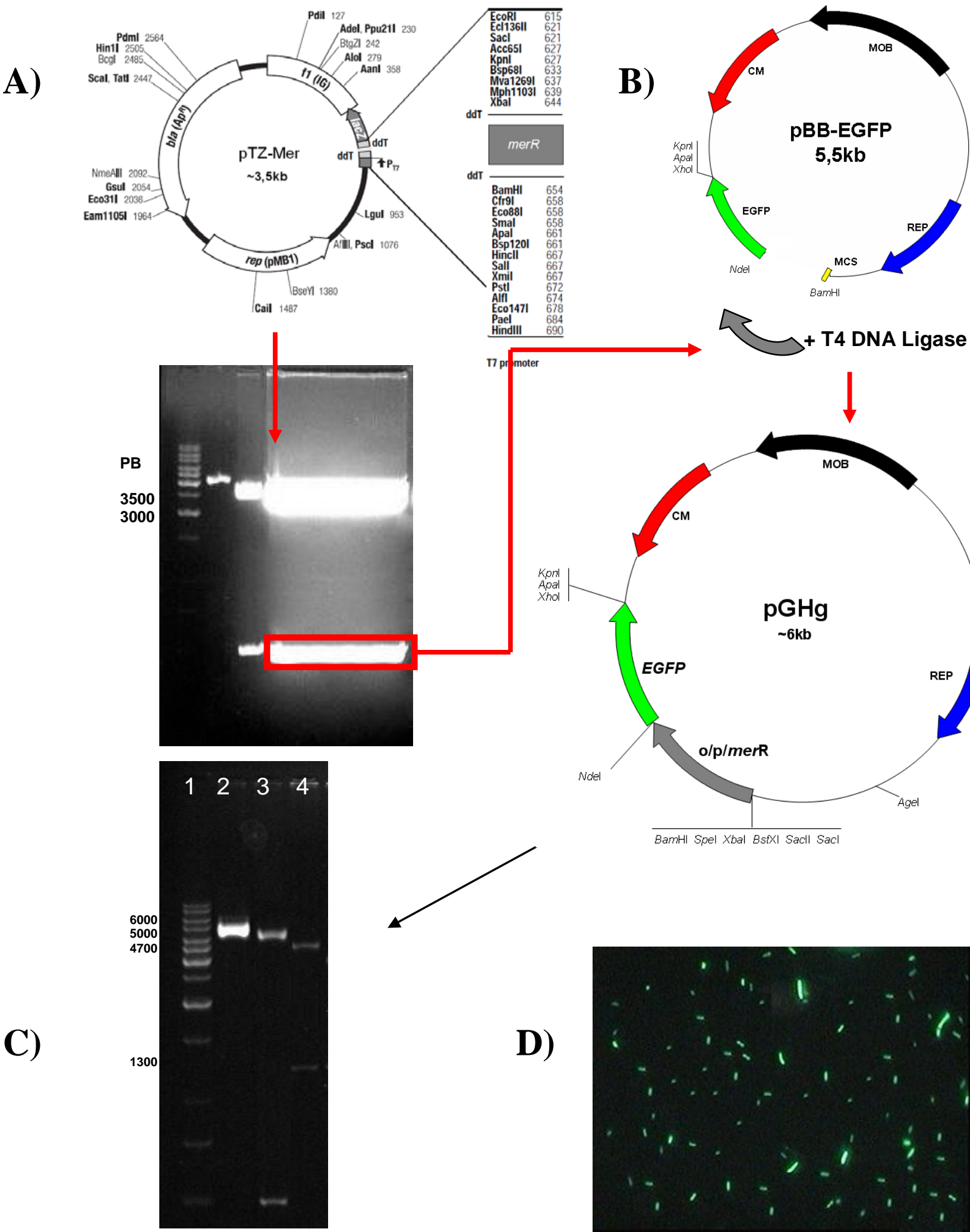

T4 DNA Ligase
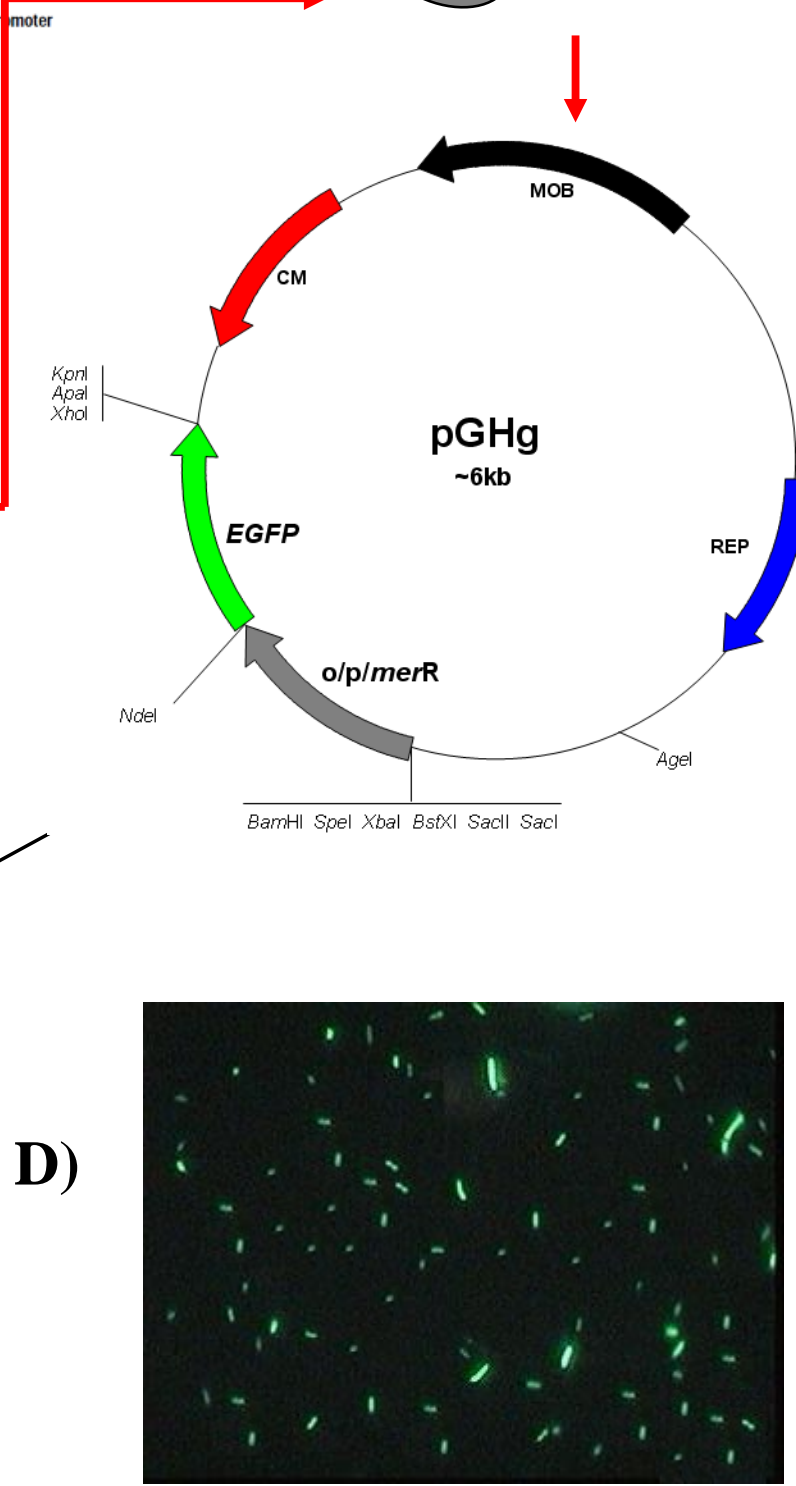

Figura 10 - A) Esquema da contrução do plasmídeo pTZ-Mer e gel de agarose 0,8\%, corado com brometo de etídio, submetido à corrida eletroforética, onde 1: Ladder 1Kb Fermentas, 2: pTZ-Mer digerido com NdeI, 3 e 4: pTZ-Mer digerido com NdeI e BamHI; B) Esquema da construção do plasmídeo biossensor de íons mercúrio pGHg; C) Perfis de migração dos fragmentos de DNA em gel de agarose $0,8 \%$, corado com brometo de etídio, submetido à corrida eletroforética, onde 1: Ladder $1 \mathrm{~Kb}$ Fermentas, 2: pGHg digerido com NdeI, 3: pGHg digerido com NdeI e BamHI, 4: pGHg digerido com XhoI e BamHI; D) Células recombinantes de E. coli DH5 / pGHg fluorescendo na presença de mercúrio (aumento de 1000X, microscopia de fluorescência, utilizando uma lâmpada de vapor de mercúrio). 
A mistura de ligação vetor-inserto foi empregada para a transformação genética de células E. coli DH5a, pelo método de eletroporação.

Algumas colônias bacterianas, resistentes ao cloranfenicol e escolhidas ao acaso, tiveram seus DNAs plasmidiais isolados, purificados e digeridos com NdeI. Este plasmídeo recombinante foi chamado de pGHg. Um plasmídeo recombinante, que se encaixava no perfil desejado (Figura 10C) foi selecionado para análises mais detalhadas. Foi observado que as células recombinantes E. coli DH5 / pGHg fluorescem na presença de mercúrio (microscopia de fluorescência, aumento de 1000X, utilizando uma lâmpada de vapor de mercúrio e câmera CCD Hitachi KP-D581) (Figura 10D).

O plasmídeo pGHg também foi empregado na transformação genética de $C$. metallidurans CH34.

\subsubsection{Análise quantitativa da expressão do gene EGFP dos clones recombinantes E. coli} DH5a / pGHg e C. metallidurans CH34 / pGHg

Os clones recombinantes foram inoculados e cultivados de acordo com o item 3.14 e 3.14.1. Para a avaliação por citometria de fluxo, as amostras foram diluídas à $1 \times 10^{-6}$ e transferidas para microtubos de $1,5 \mathrm{ml}$, onde a expressão do gene EGFP dos clones recombinantes foi quantificada. As leituras das intensidades de fluorescências relativas (IFR) emitidas estão apresentadas nas Figuras 11, 12, 13 e 14.

O clone C. metallidurans $\mathrm{CH} 34$ / pGHg inoculado em $\mathrm{H}_{2} \mathrm{O}$ tem baixa expressão do gene EGFP, sendo pouco significafiva, mas C. metallidurans CH34 / pGHg inoculado em Caldo Nutriente foi capaz de detectar íons mercúrio na faixa compreendida entre 80 a 0,1563 $\mu \mathrm{M}$ de $\mathrm{HgCl}_{2}$, com altas leituras de IFR, chegando a picos de 360 .

Já o clone E. coli DH5 / pGHg inoculado em $\mathrm{H}_{2} \mathrm{O}$ obteve excelente desempenho na expressão, detectando íons mercúrio na faixa compreendida entre 625 a 0,0024 nM de $\mathrm{HgCl}_{2}$, com altas taxas de fluorescência, chegando a 540 IFR. Quando inoculado em Caldo Nutriente, E. coli DH5a / pGHg foi capaz de detectar íons mercúrio na faixa ou pouco menor, entre 625 a 2,441 nM de $\mathrm{HgCl}_{2}$. 


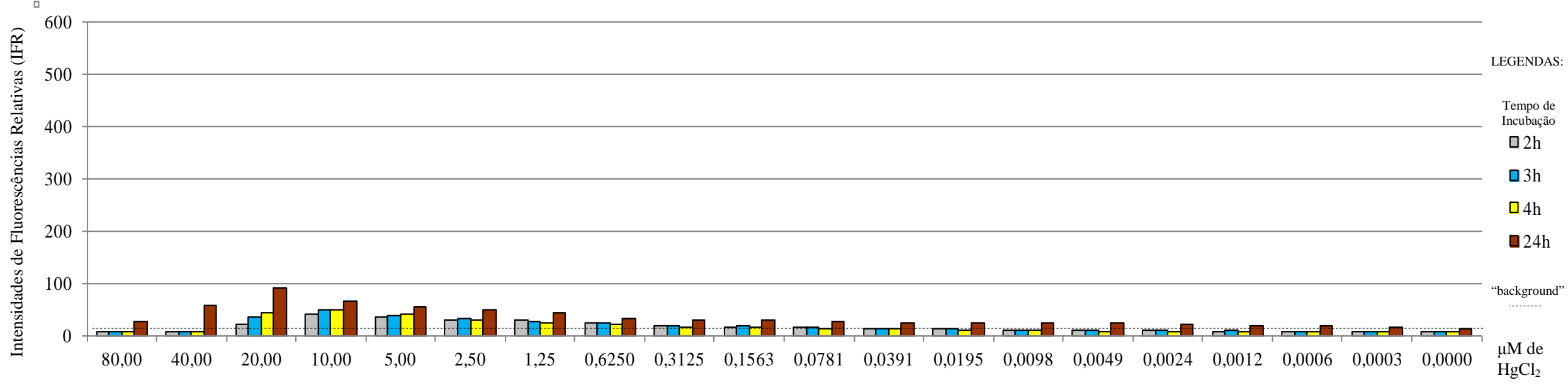

Figura 11 - Gráfico das diferentes intensidades de fluorescência do clone C. metallidurans CH34/pGHg inoculado em $\mathrm{H}_{2} \mathrm{O}$, com diferentes concentrações de $\mathrm{HgCl}_{2}$, no intervalo de tempo de $2 \mathrm{~h}, 3 \mathrm{~h}, 4 \mathrm{~h}$ e $24 \mathrm{~h}$, incubado à $28{ }^{\circ} \mathrm{C}$.

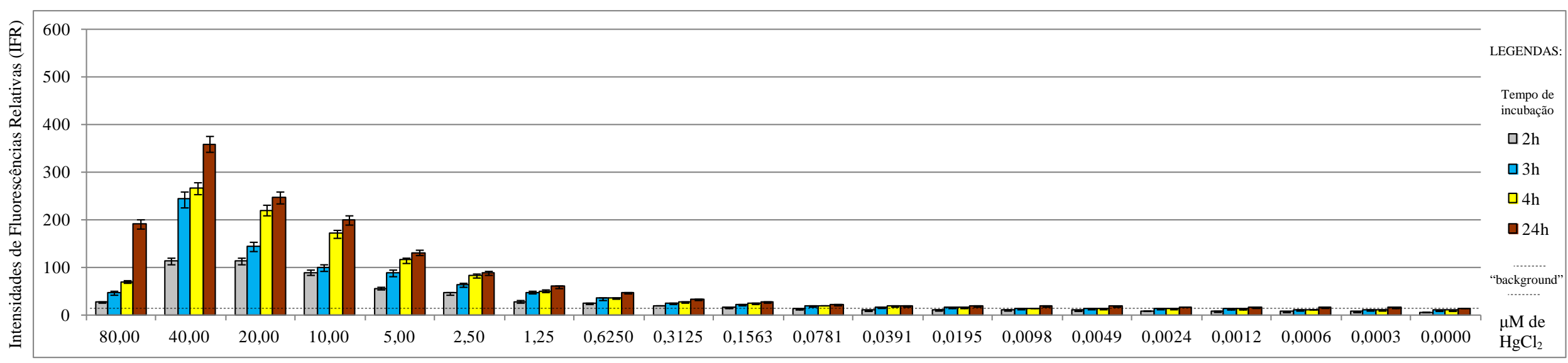

Figura 12 - Gráfico das diferentes intensidades de fluorescência do clone C. metallidurans $\mathrm{CH} 34 / \mathrm{pGHg}$ inoculado em Caldo Nutriente, com diferentes concentrações de $\mathrm{HgCl}_{2}$ no intervalo de tempo de $2 \mathrm{~h}, 3 \mathrm{~h}, 4 \mathrm{~h}$ e $24 \mathrm{~h}$, incubado à $28^{\circ} \mathrm{C}$. 


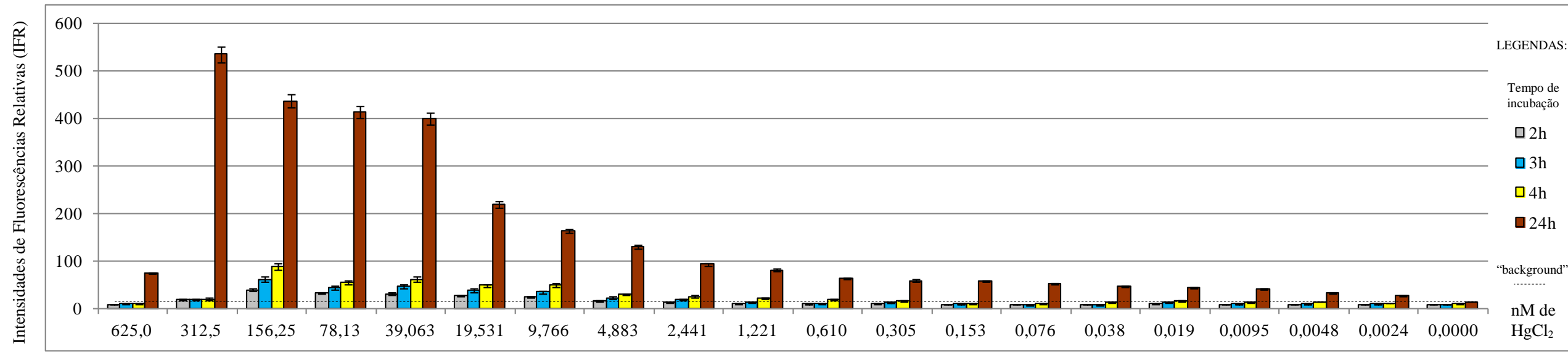

Figura 13 - Gráfico das diferentes intensidades de fluorescência do clone $E$. coli DH5 $\alpha / p G H g$ inoculado em $\mathrm{H}_{2} \mathrm{O}$, com diferentes concentrações de $\mathrm{HgCl}_{2}$, no intervalo de tempo de $2 \mathrm{~h}, 3 \mathrm{~h}, 4$ h e $24 \mathrm{~h}$, incubado à $37^{\circ} \mathrm{C}$.

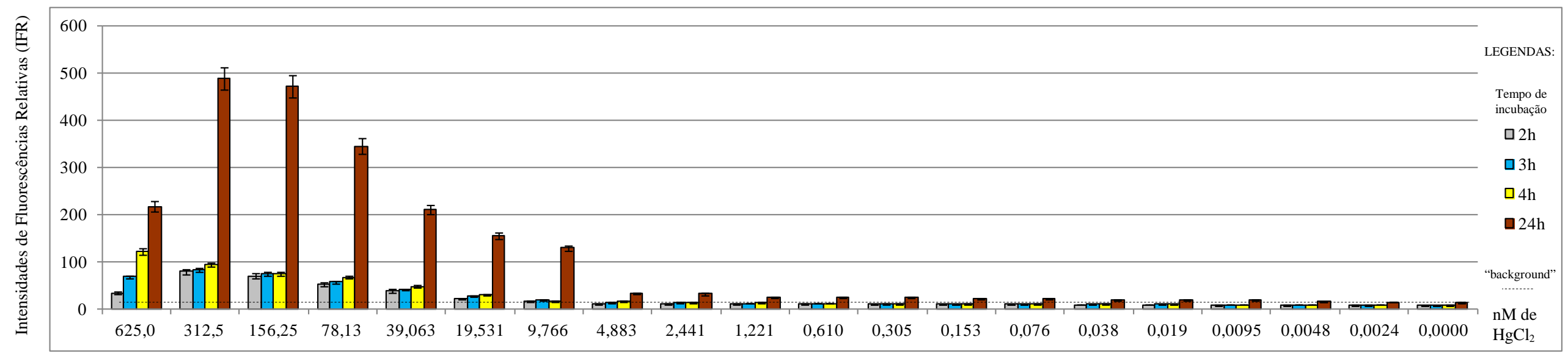

Figura 14 - Gráfico das diferentes intensidades de fluorescência do clone E. coli DH5 $\alpha / p G H g$ inoculado em Caldo Nutriente, com diferentes concentrações de $\mathrm{HgCl}_{2}$, no intervalo de tempo de $2 \mathrm{~h}, 3 \mathrm{~h}, 4 \mathrm{~h}$ e $24 \mathrm{~h}$, incubado à $37^{\circ} \mathrm{C}$. 


\subsection{Biossensor de Arsênio.}

\subsubsection{Contrução do plasmídeo pGAs - Biossensor de $\mathrm{As}^{3+}$}

Para a obtenção do plasmídeo biossensor de $\mathrm{As}^{3+}$ (pGAs) foram realizadas as manipulações esquematizadas na Figura 15 e 16, apresentadas a seguir.

O fragmento de DNA correspondente ao gene OP/arsR, foi amplificado por PCR. Para tanto, foram empregados o DNA total de C. metallidurans CH34, como molde, e os oligonucleotídeos iniciadores arsR-primerF (com o sítio da enzima PstI): e arsR-primerR (com o sítio NdeI) (Tabela 4).

O fragmento de DNA obtido, foi ligado ao vetor pTZ57R/T, (Figura 15A). A mistura de ligação foi empregada na transformação genética, por eletroporação, de células E. coli DH5 $\alpha$.

Algumas colônias bacterianas, resistentes à ampicilina e escolhidas ao acaso, tiveram seus DNAs plasmidiais isolados, purificados e digeridos com NdeI. Os plasmídeos extraídos de dois clones recombinantes que se encaixavam aos perfis desejados foram selecionados para análises mais detalhadas. Estes plasmídeos recombinantes foram digeridos com as enzimas de restrição NdeI, XhoI e analisados em gel de agarose submetido a eletroforese, confirmando-se a construção do plasmídeo desejado pTZ-Ars (Figura 15B).

Para a construção do plasmídeo pGAs, os plasmídeos pTZ-Ars e pBB-EGFP foram digeridos com as enzimas de restrição NdeI e SacI. O fragmento OP/arsR liberado e o plasmídeo pBB-EGFP previamente digerido foram purificados e usados na mistura de ligação, utilizando a enzima T4 DNA ligase (Figura 16A).

A mistura de ligação vetor-inserto foi empregada para a transformação genética de células E. coli DH5a, pelo método de eletroporação.

Algumas colônias bacterianas, resistentes ao cloranfenicol, escolhidas ao acaso, tiveram seus DNAs plasmidiais isolados, purificados e digeridos com NdeI. Um plasmídeo recombinante, que se encaixava no perfil desejado foi selecionado para análises mais detalhadas. Este plasmídeo recombinante foi digerido com as enzimas de restrição NdeI, SacII, SalI, XhoI e analisado em gel de agarose submetido a eletroforese (Figura 16B). O novo plasmídeo foi denominado pGAs.

O plasmídeo pGAs também foi empregado na transformação genética de $C$. metallidurans CH34. 
A)
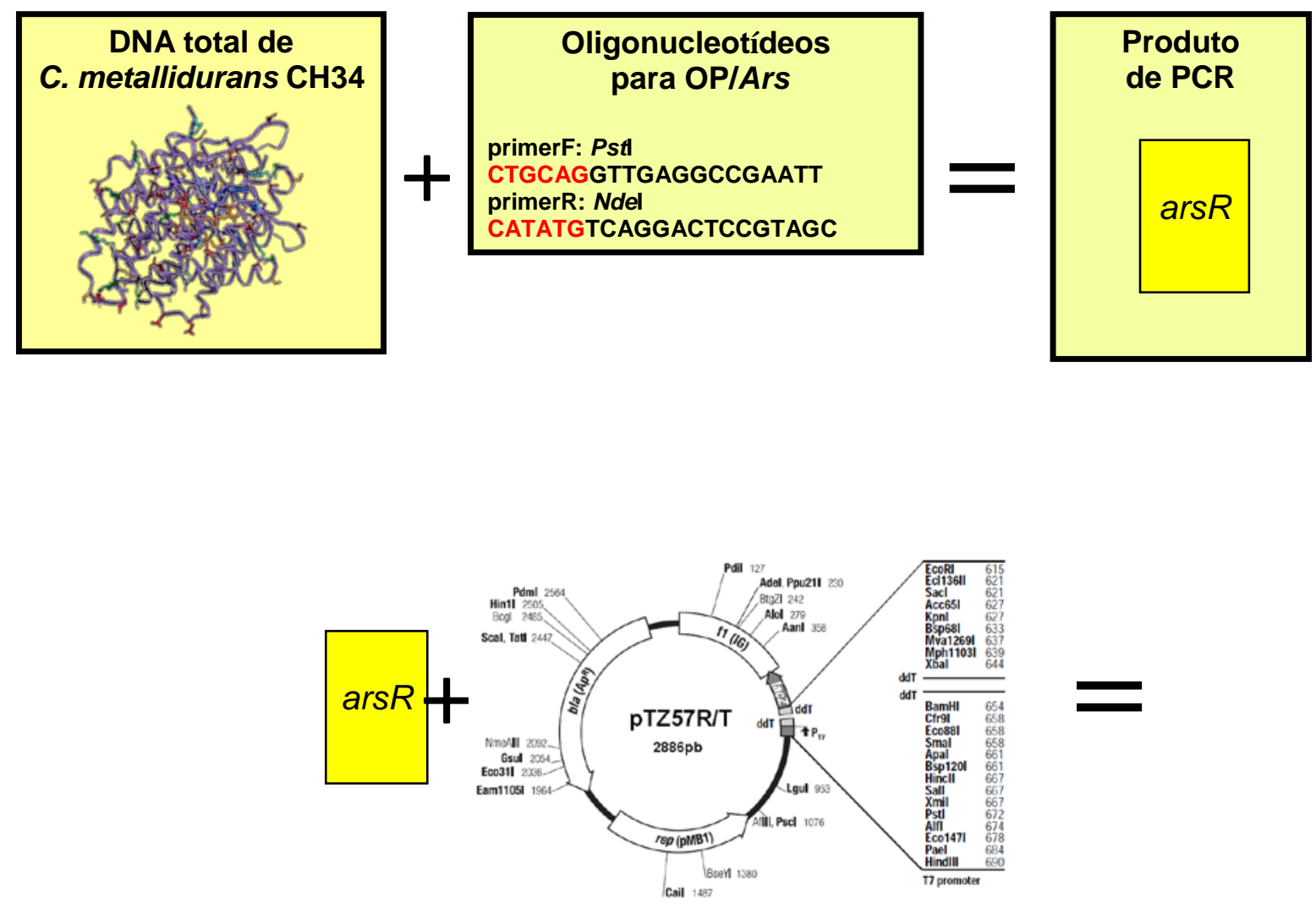

B)

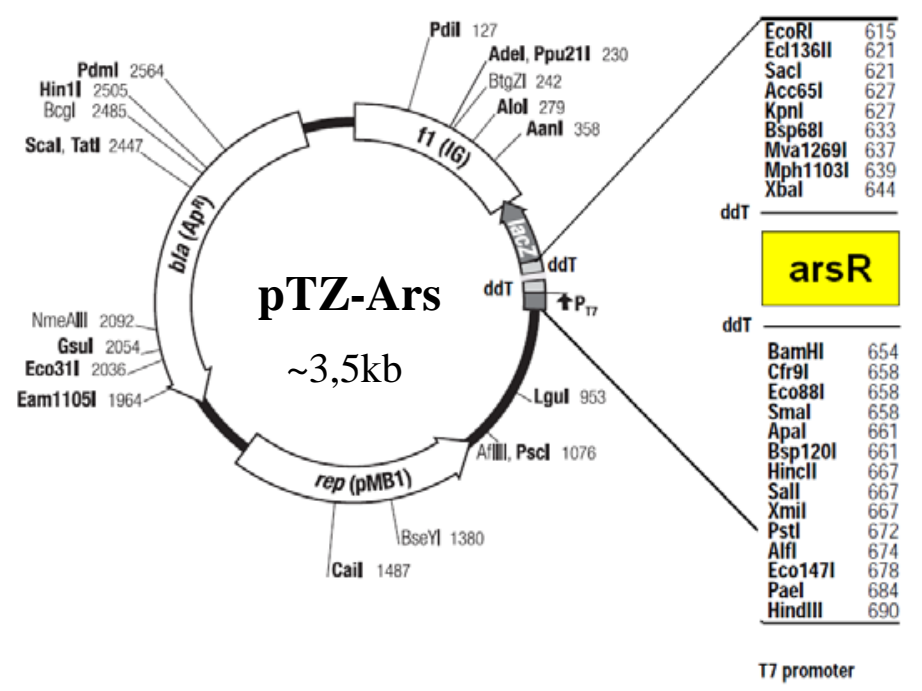

B)

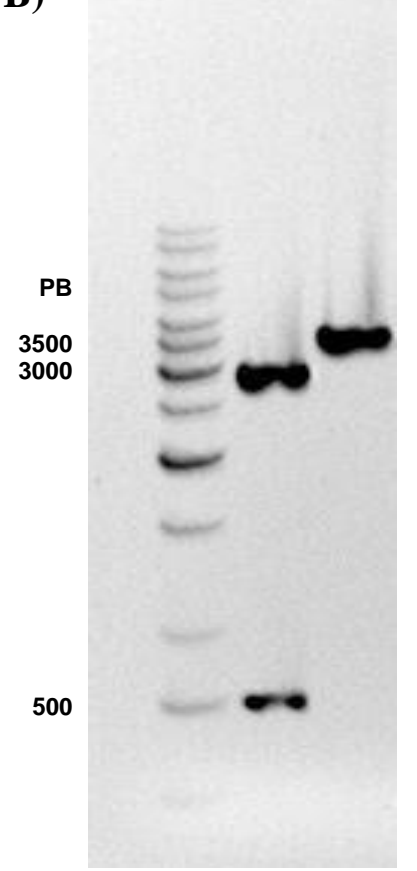

Figura 15 - A) Esquema da construção do plasmídeo pTZ-Ars; B) Perfis de migração dos fragmentos de DNA analisados em gel de agarose $0,8 \%$, corado com brometo de etídio, submetido à corrida eletroforética, onde, 1: Marcador de tamanho molecular - Ladder 1kb 50ng/ $\mu \mathrm{L}$ (Fermentas); 2: pTZ-Ars digerido com NdeI e XhoI; 3: pTZ-Ars digerido com NdeI. 
A)
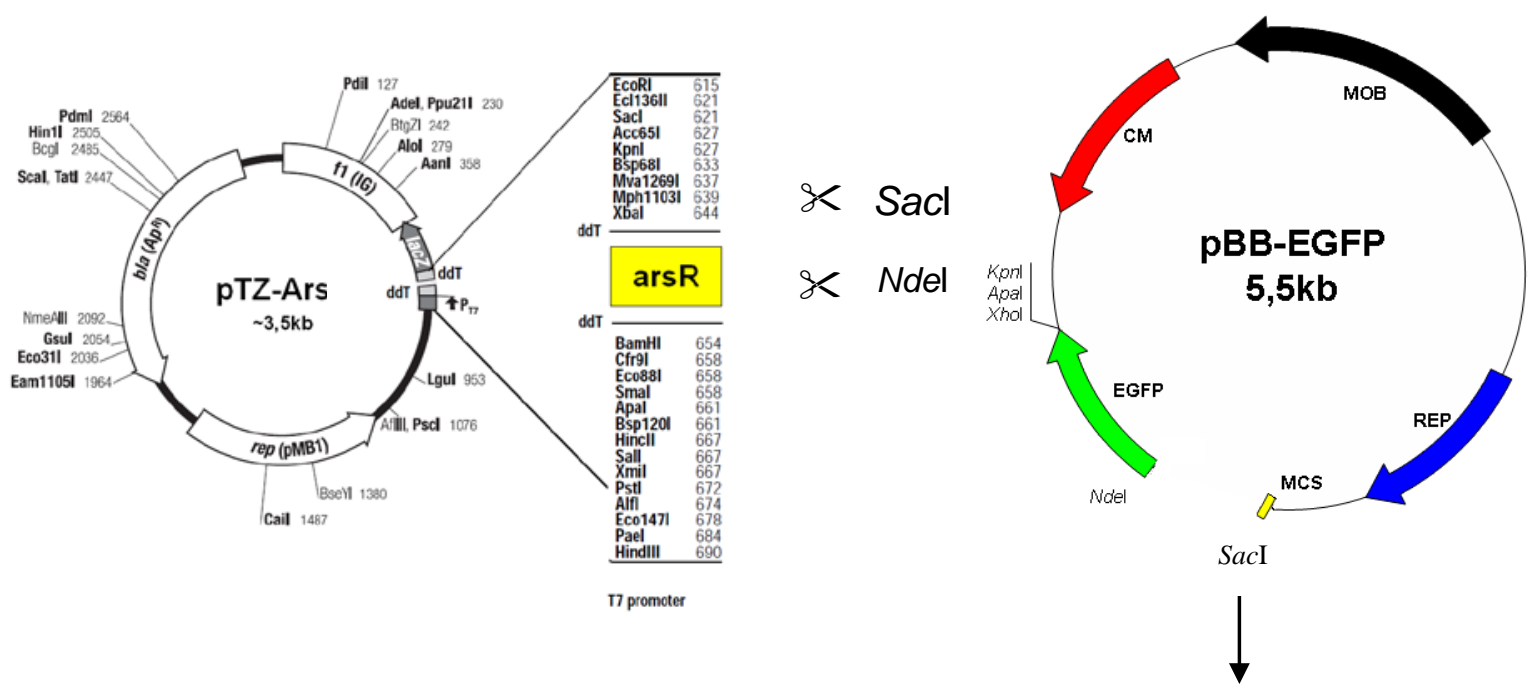

Inserto + vetor + T4 DNA ligase
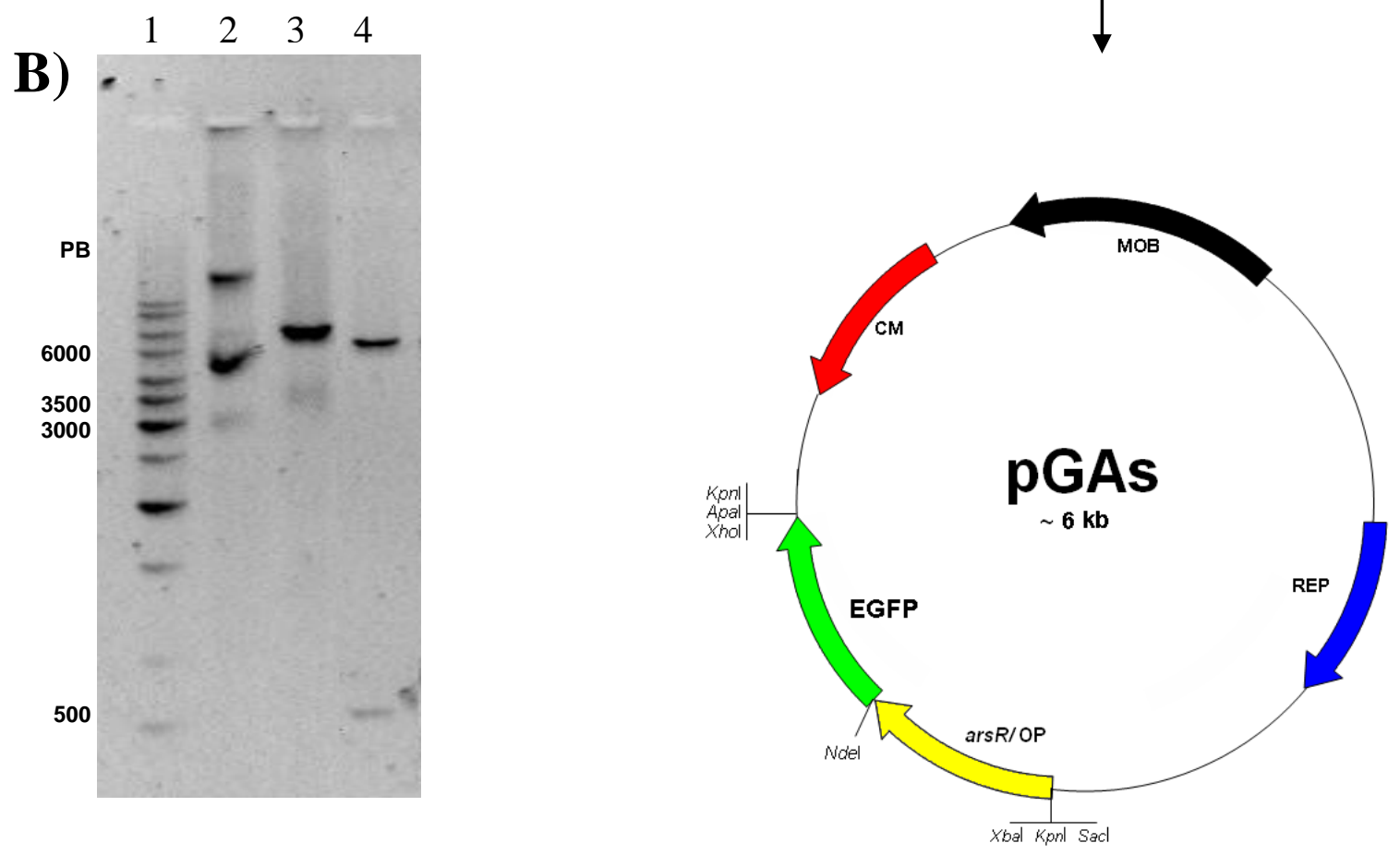

Figura 16 - A) Esquema da construção dos plasmídeos pGAs; B) Perfis de migração dos fragmentos de DNA em gel de agarose $0,8 \%$, corado com brometo de etídio, submetido à corrida eletroforética, onde, 1 : Marcador de tamanho molecular - Ladder 1kb 50ng/ $\mu \mathrm{L}$ (Fermentas); 2 pGAs-Cm não digerido; 3: pGAs-Cm digerido com NdeI; 4- pGAs-Cm digerido com NdeI e SacI. 
4.2.3 Análise quantitativa da expressão do gene EGFP dos clones recombinantes E. coli DH5a / pGAs e C. metallidurans CH34 / pGAs

Os clones recombinantes foram inoculados e cultivado de acordo com o item 3.14 e 3.14.2. Para a avaliação por citometria de fluxo, as amostras foram diluídas à $1 \times 10^{-6}$ e transferidas para microtubos de $1,5 \mathrm{ml}$, onde a expressão do gene EGFP dos clones recombinantes foi quantificada. As leituras das intensidades de fluorescências relativas (IFR) emitidas estão apresentadas nas Figuras 17, 18, 19 e 20.

O clone C. metallidurans CH34 / pGAs inoculado em Caldo Nutriente foi capaz de detectar íons arsênio na faixa compreendida entre 200 a 0,0244 mM de $\mathrm{Na}_{2} \mathrm{HAsO}_{4} .7 \mathrm{H}_{2} \mathrm{O}$, com picos de 165 IFR.

Já os clones C. metallidurans CH34 / pGAs inoculado em $\mathrm{H}_{2} \mathrm{O}$ e E. coli DH5a / pGAs inoculado em $\mathrm{H}_{2} \mathrm{O}$ e Caldo Nutriente, não obtiveram significativa expressão do EGFP, consequentemente baixos valores de IFR. 


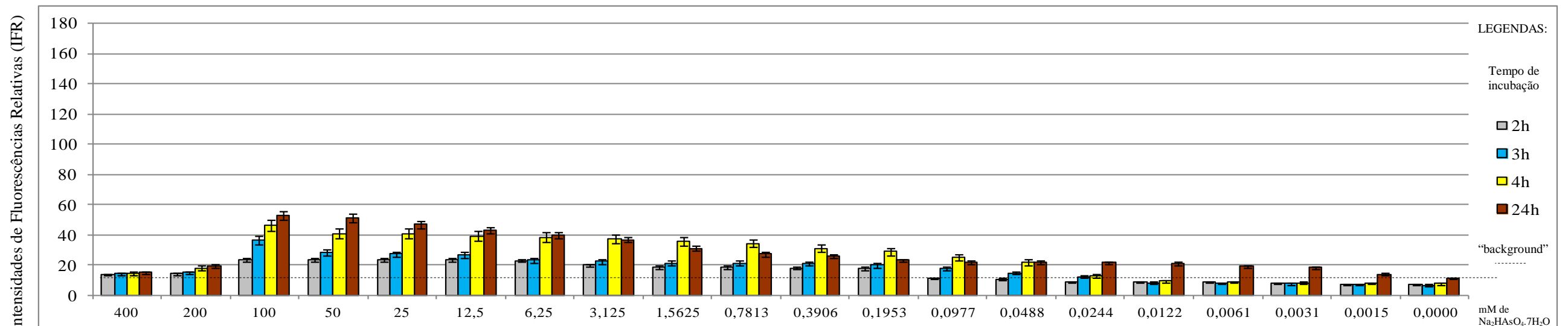

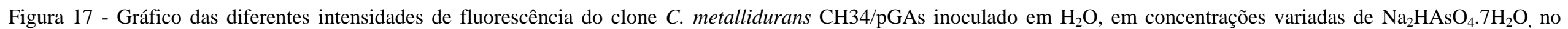
intervalo de tempo de 2 h, 3 h, 4 h e 24 h, incubado à $28^{\circ} \mathrm{C}$.

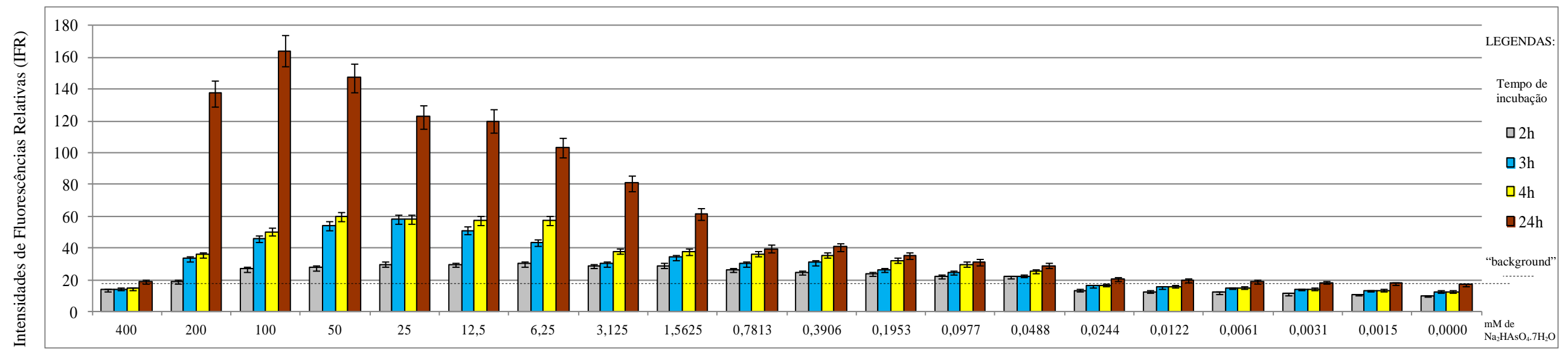

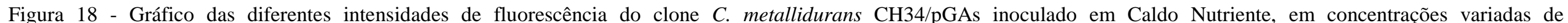
$\mathrm{Na}_{2} \mathrm{HAsO}_{4} .7 \mathrm{H}_{2} \mathrm{O}$, no intervalo de tempo de $2 \mathrm{~h}$, 3h, 4h e $24 \mathrm{~h}$, incubado à $28^{\circ} \mathrm{C}$. 


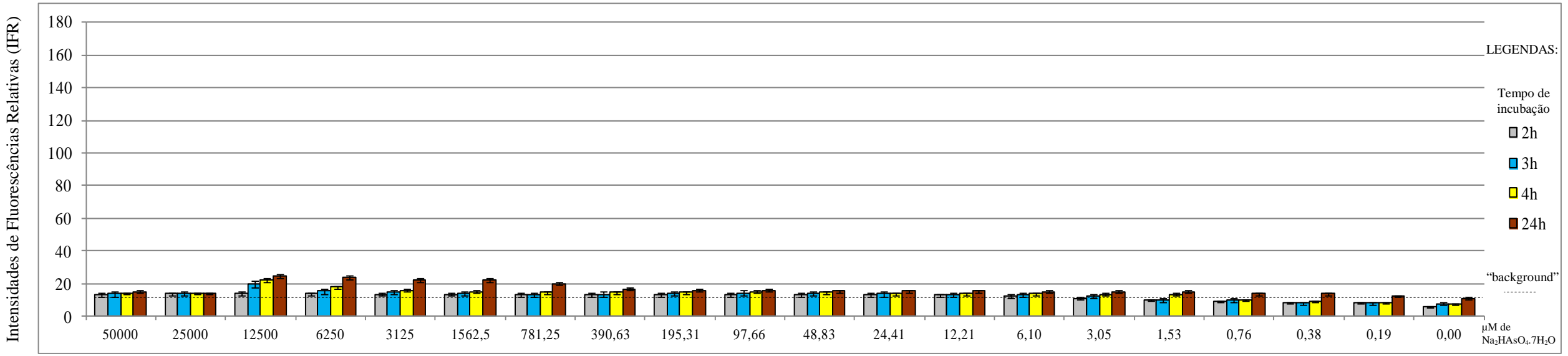

Figura 19 - Gráfico das diferentes intensidades de fluorescência do clone E. coli $\mathrm{DH} 5 \alpha \mathrm{CH} 34 / \mathrm{pGAs}$ inoculado em $\mathrm{H}_{2} \mathrm{O}$, em concentrações variadas de $\mathrm{Na}_{2} \mathrm{HAsO}_{4} \cdot 7 \mathrm{H}_{2} \mathrm{O}$ no intervalo de tempo de $2 \mathrm{~h}$, $3 \mathrm{~h}$, $4 \mathrm{~h}$ e $24 \mathrm{~h}$, incubado à $37^{\circ} \mathrm{C}$.

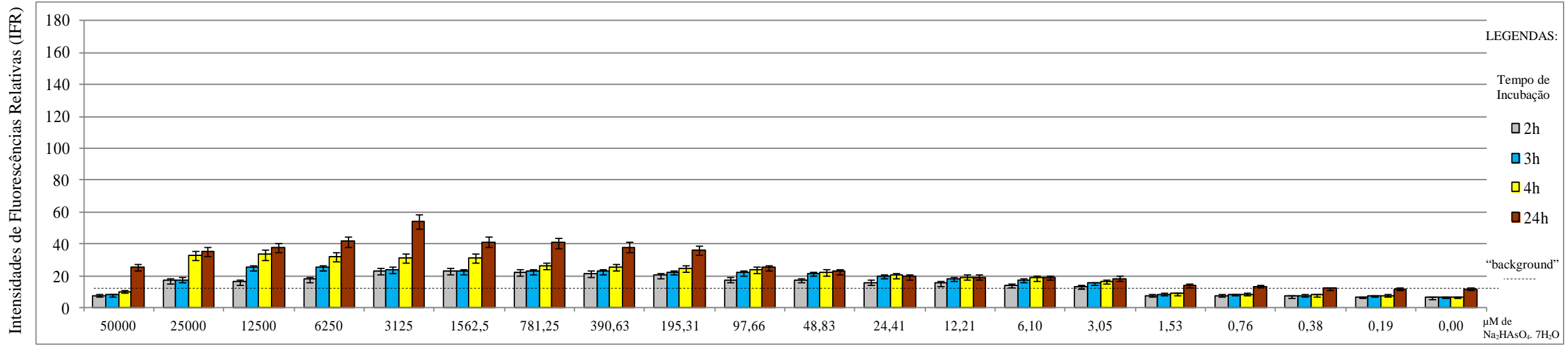

Figura 20 - Gráfico das diferentes intensidades de fluorescência do clone E. coli DH5 $\alpha$ CH34/pGAs inoculado em Caldo Nutriente, em concentrações variadas de $\mathrm{Na}_{2} \mathrm{HAsO}_{4} \cdot 7 \mathrm{H}_{2} \mathrm{O}$, no intervalo de tempo de 2h, 3h, 4h e 24h, incubado à $37^{\circ} \mathrm{C}$. 


\subsection{Biossensor de Chumbo.}

\subsubsection{Contrução do plasmídeo pGPb - Biossensor de $\mathbf{P b}^{2+}$}

Para a obtenção do plasmídeo biossensor de $\mathrm{Pb}^{2+}$ (pGPb), foram realizadas as manipulações esquematizadas nas Figuras 21e 22, apresentadas a seguir.

O fragmento de DNA correspondente ao gene $p b r R / O P$ foi obtido por PCR. Para tanto, foram empregados o DNA total de C. metallidurans CH34, como molde e os oligonucleotídeos pbrR-primerF (com o sítio da enzima BamHI) e pbrR-primerR (com o sítio NdeI): (Tabela 4).

O amplicom $p b r R / O P$ obtido por PCR foi ligado ao vetor pTZ57R/T (Figura 21A). A mistura de ligação foi empregada na transformação genética, por eletroporação, de células $E$. coli DH5 $\alpha$.

Algumas colônias bacterianas, resistentes à ampicilina, ecolhidas ao acaso, tiveram seus DNAs plasmidiais isolados e purificados. Os plasmídeos extraídos de clones recombinantes que se encaixavam aos perfis desejados foram selecionados para análises mais detalhadas. Estes plasmídeos recombinantes foram digeridos com as enzimas de restrição NdeI, SacI, XbaI e BamHI, analisados em gel de agarose, confirmando-se a construção do plasmídeo desejado pTZ-Pbr (Figura 21B).

Para a construção do plasmídeo pGPb, os plasmídeos pBB-EGFP e pTZ-Pbr foram, primeiramente, digeridos com as enzimas NdeI e SacI. Em seguida, foi realizada um mistura de ligação do fragmento pbrR/OP e o vetor pBB-EGFP digerido (Figura 22A).

A mistura de ligação foi empregada na transformação genética de células $E$. coli DH5 $\alpha$, pelo método de eletroporação.

Colônias bacterianas, resistentes ao cloranfenicol, ecolhidas ao acaso, tiveram seus DNAs plasmidiais isolados, purificados e digeridos com NdeI. Um plasmídeo recombinante, que se encaixava no perfil desejado foi selecionado para análises mais detalhadas. Este plasmídeo recombinante foi chamado de pGPb (Figura 22B).

O plasmídeo pGPg também foi empregado na transformação genética de $C$. metallidurans $\mathrm{CH} 34$. 


\section{A)}
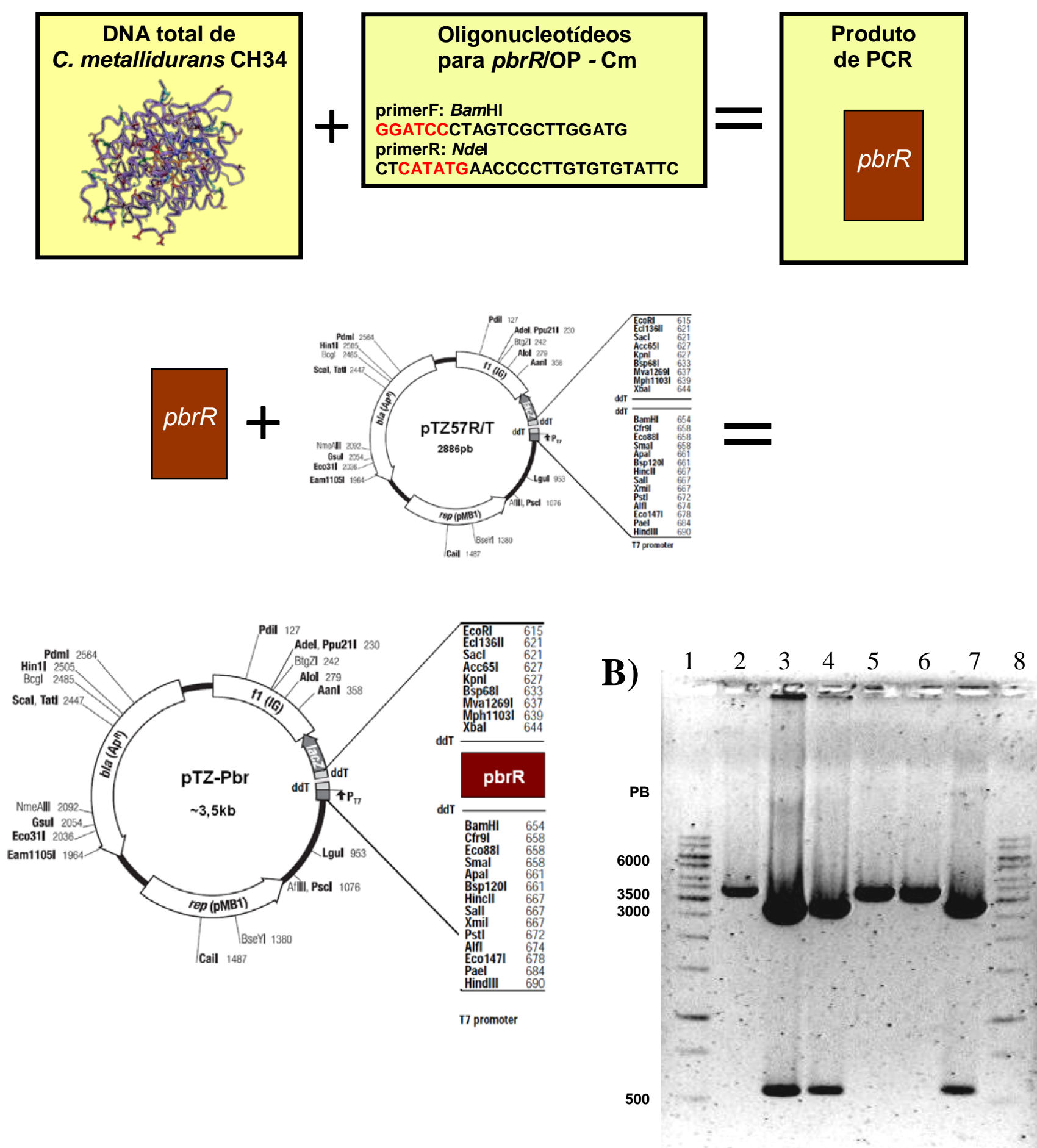

Figura 21 - A) Esquema da construção do plasmídeos pTZ-Pbr; B) Perfis de migração dos fragmentos de DNA em gel de agarose $0,8 \%$, corado com brometo de etídio, submetido à corrida eletroforética, onde, 1 e 8: Marcador de tamanho molecular - Ladder $1 \mathrm{~kb} 50 \mathrm{ng} / \mu \mathrm{L}$ (Fermentas); 2 a 7 pTZ-Pbr digeridos, sendo: 2- NdeI; 3- NdeI e SacI; 4- NdeI e XbaI; 5- XbaI; 6- BamHI.; 7- NdeI e BamHI. 
A)
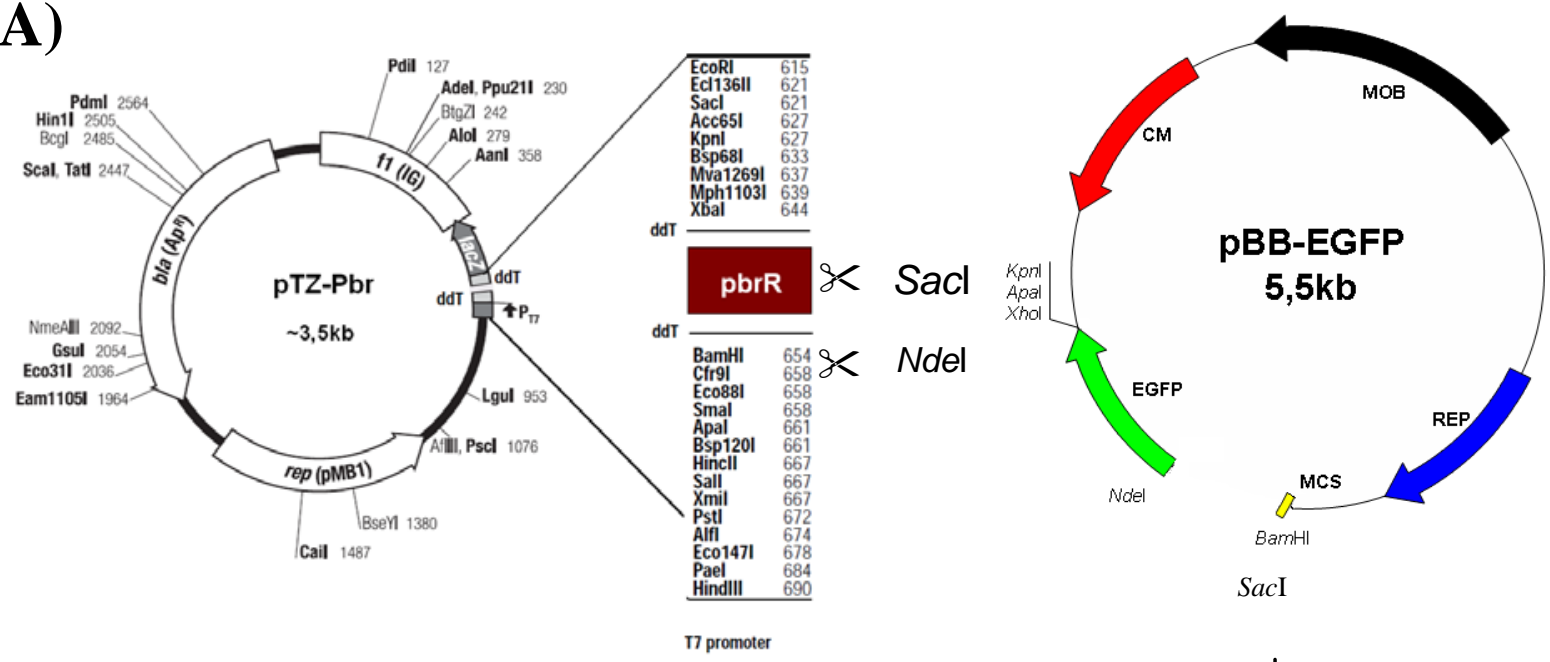

77 promoter

B)
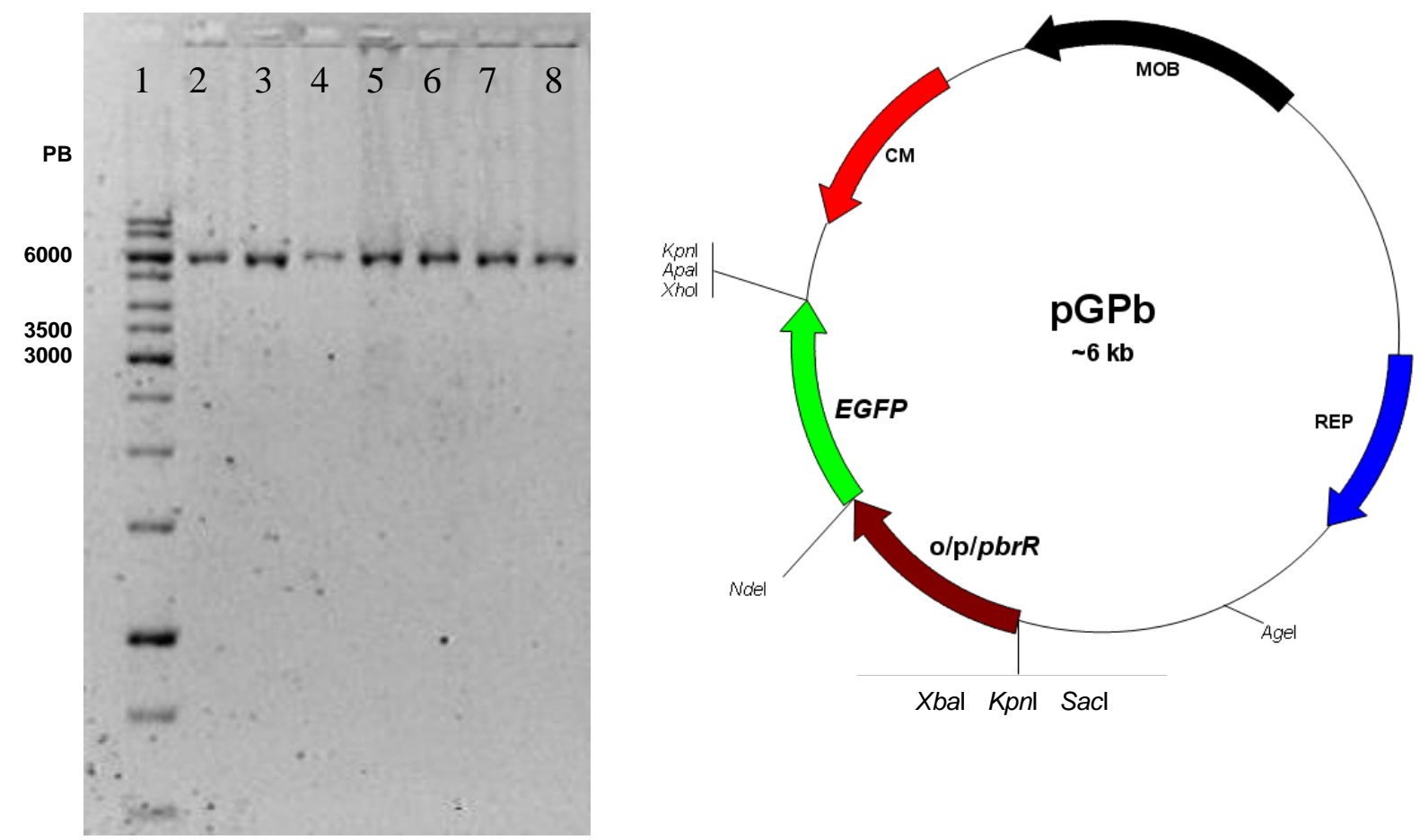

Figura 22 - A) Esquema da construção do plasmídeo pGPb; B) Perfis de migração dos fragmentos de DNA em gel de agarose $0,8 \%$, corado com brometo de etídio, submetido à corrida eletroforética, onde, 1: Marcador de tamanho molecular - Ladder $1 \mathrm{~kb} 50 \mathrm{ng} / \mu \mathrm{L}$ (Fermentas); 2 a 8 plasmídeos pGPb digeridos com NdeI. 
4.3.2 Análise quantitativa da expressão do gene EGFP dos clones recombinantes $E$. coli DH5a / pGPb e C. metallidurans CH34 / pGPb

Os clones recombinantes foram inoculados e cultivado de acordo com o item 3.14 e 3.14.3. Para a avaliação por citometria de fluxo, as amostras foram diluídas à $1 \times 10^{-6}$ e transferidas para microtubos de $1,5 \mathrm{ml}$, onde a expressão do gene EGFP dos clones recombinantes foi quantificada. As leituras das intensidades de fluorescências relativas (IFR) emitidas estão apresentadas nas Figuras 23, 24, 25 e 26.

$\mathrm{O}$ clone C. metallidurans $\mathrm{CH} 34$ / pGPb inoculado em $\mathrm{H}_{2} \mathrm{O}$ foi capaz de detectar íons chumbo na faixa compreendida entre 625 a 0,31 $\mu \mathrm{M}$ de $\mathrm{Pb}\left(\mathrm{NO}_{3}\right)_{2}$, com 225 IFR.

Já os clones C. metallidurans CH34 / pGPb inoculado em Caldo Nutriente e E. coli DH5 $\alpha$ / pGPb inoculado em $\mathrm{H}_{2} \mathrm{O}$ e Caldo Nutriente, não obtiveram significativa expressão do EGFP, consequentemente baixos valores de IFR. 


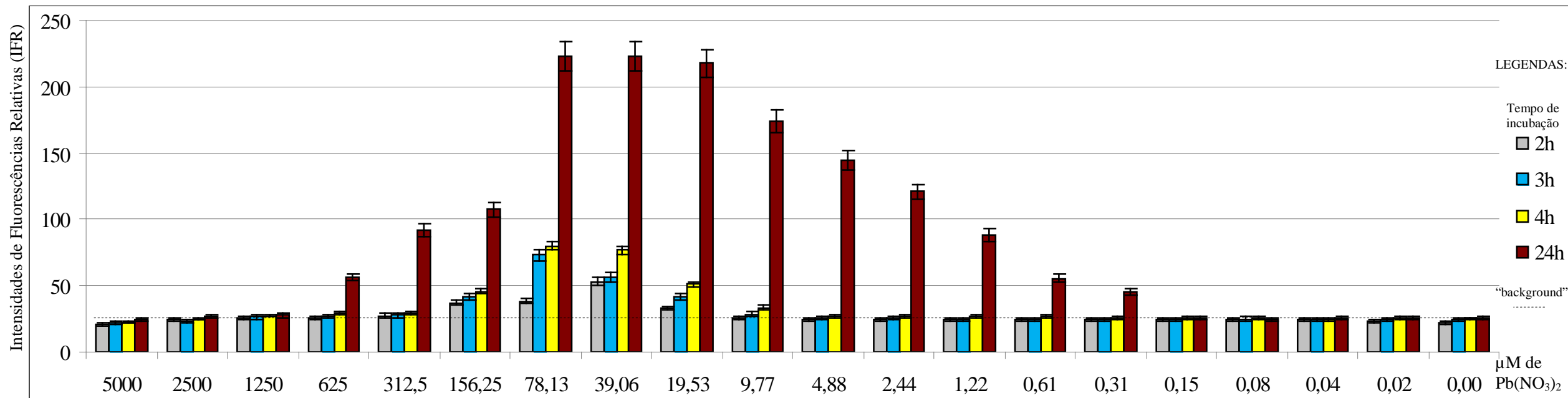

Figura 23 - Gráfico das diferentes intensidades de fluorescência do clone C. metallidurans $\mathrm{CH} 34 / \mathrm{pGPb}$ inoculado em $\mathrm{H}_{2} \mathrm{O}$, em concentrações variadas de $\mathrm{Pb}\left(\mathrm{NO}_{3}\right)_{2}$, no intervalo de tempo de $2 \mathrm{~h}, 3 \mathrm{~h}, 4 \mathrm{~h}$ e $24 \mathrm{~h}$, incubado à $28{ }^{\circ} \mathrm{C}$

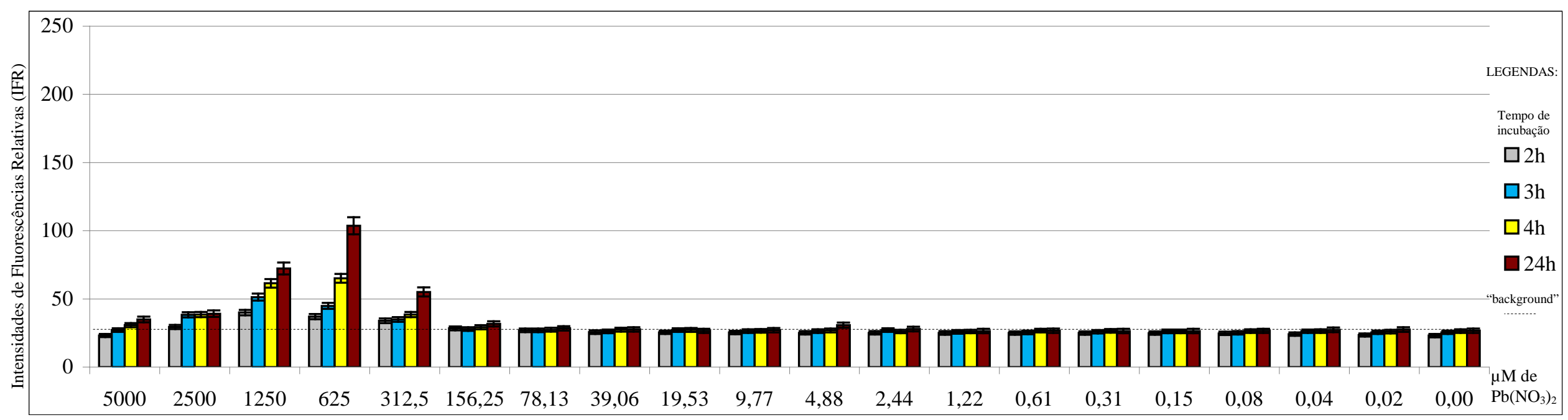

Figura 24 - Gráfico das diferentes intensidades de fluorescência do clone C. metallidurans CH34/pGPb inoculado em Caldo Nutriente, em concentrações variadas de $\mathrm{Pb}\left(\mathrm{NO}_{3}\right)_{2}$, no intervalo de tempo de $2 \mathrm{~h}$, $3 \mathrm{~h}$, $4 \mathrm{~h}$ e $24 \mathrm{~h}$, incubado à $28{ }^{\circ} \mathrm{C}$. 


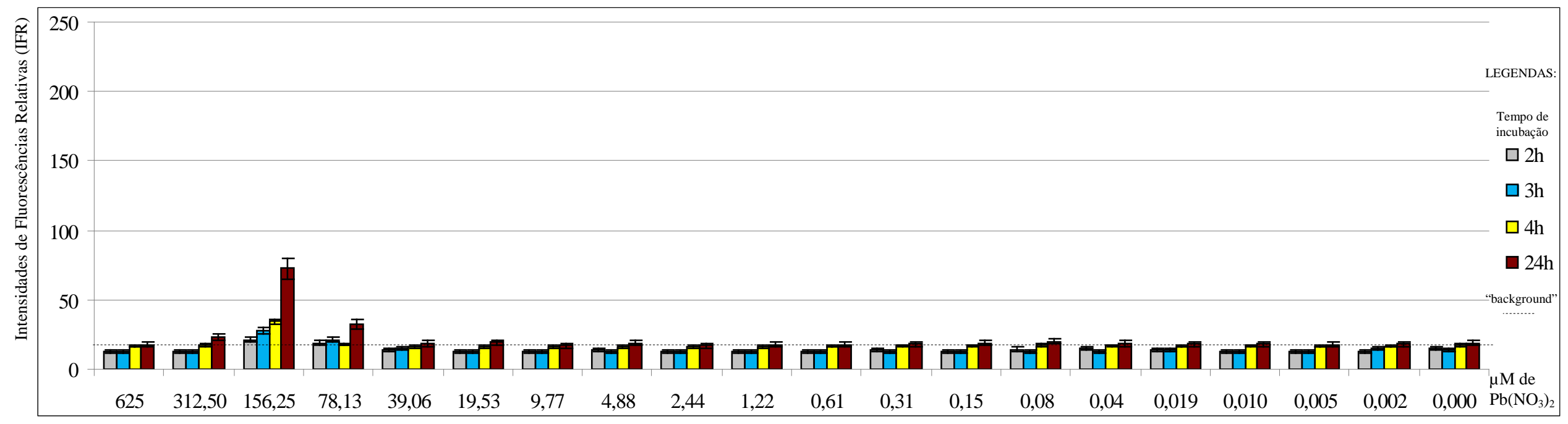

Figura 25 - Gráfico das diferentes intensidades de fluorescência do clone $E$. coli $D H 5 \alpha / \mathrm{pGPb}$ inoculado em $\mathrm{H}_{2} \mathrm{O}$, em concentrações variadas de $\mathrm{Pb}\left(\mathrm{NO}_{3}\right)_{2}$, no intervalo de tempo de $2 \mathrm{~h}$, 3h, $4 \mathrm{~h}$ e $24 \mathrm{~h}$, incubado à $37^{\circ} \mathrm{C}$.

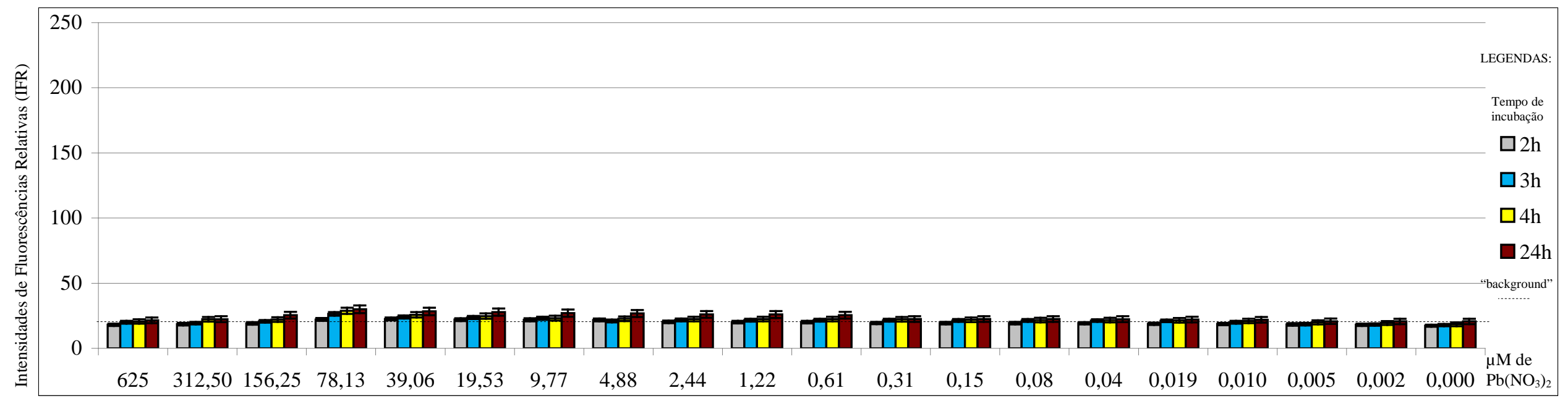

Figura 26 - Gráfico das diferentes intensidades de fluorescência do clone E. coli $D H 5 \alpha / \mathrm{pGPb}$ inoculado em Caldo Nutriente, em concentrações variadas de $\mathrm{Pb}\left(\mathrm{NO}_{3}\right)_{2}$, no intervalo de tempo de $2 \mathrm{~h}, 3 \mathrm{~h}$, $4 \mathrm{~h}$ e $24 \mathrm{~h}$, incubado à $37^{\circ} \mathrm{C}$. 
5 DISCUSSÃO 
Os metais mercúrio, arsênio, chumbo são altamente tóxicos ao organismo humano (Tabela 1). De acordo a Companhia Ambiental do Estado de São Paulo (CETESB, 2010):

- A principal via de exposição humana ao mercúrio é o consumo de pescados (e mamíferos marinhos) contaminados por metilmercúrio (MeHg). O MeHg, que é a forma mais tóxica do mercúrio, bioacumula nos animais, havendo biomagnificação na cadeia alimentar.

- Mais de $80 \%$ do chumbo que ingressa no organismo é oriundo da ingestão de alimentos, sujeiras e poeira contendo o metal.

Um estudo publicado por Figueiredo (2009) aponta o teor de metais em solos superficiais de 14 parques públicos do município de São Paulo e revelou elevada presença de metais potencialmente tóxicos, principalmente chumbo e arsênio, comparados com os valores de referências da CETESB:

- A concentração de arsênio é de 39 mg/kg nos parques Ibirapuera, Aclimação, Trianon e Vila dos Remédios; 40mg/kg no parque Chico Mendes e 56 mg/kg no da Luz, valor de referência 35 mg/kg.

- Foram encontradas elevadas concentrações de chumbo nos parques Buenos Aires (439 mg/kg), Luz (209 mg/kg), Trianon (230 mg/kg) e Aclimação (260 $\mathrm{mg} / \mathrm{kg}$ ) - valor de referência $180 \mathrm{mg} / \mathrm{kg}$.

Efluentes domésticos, industriais e de mineração possuem comumente uma mistura de metais, podendo haver a prevalência de um determinado metal (Biondo, 2008).

Sendo assim, biossensores bacterianos podem ser utilizados no monitoramento, biodisponibilidade e quantificação de mercúrio, arsênio e chumbo. Sendo assim, este trabalho, visou o desenvolvimento de novas ferramentas biotecnológicas e através de técnicas de engenharia genética, três biossensores bacterianos foram construídos, cada um deles especificamente capaz de detectar e quantificar os metais pesados mercúrio, arsênio e chumbo em amostras ambientais.

\subsection{Expressão do gene EGFP nos três biossensores bacterianos}

A maioria dos biossensores bacterianos descritos atualmente é o resultado da clonagem de um promotor a montante de um cassete de gene repórter e consequente 
transferência da construção do plasmídeo em cepas específicas (Liu X, 2010). A escolha do gene EGFP foi importante porque:

- A proteína EGFP não altera a fisiologia bacteriana e não requer indutor para produzir fluorescência (Tauriainen et al., 1999);

- Como repórter, permitiu a obtenção de fluorescência estável e, portanto, aplicável em ensaios de curto e longo prazo (Li et al., 1997).

As análises quantitativas da expressão do gene EGFP nos três biossensores construídos mostraram a eficácia do plasmídeo pBB-EGFP (Quadros, 2007) (Figura 4), onde foi possível estabelecer técnicas muito parecidas para clonagem dos genes sensores.

\subsection{Operons específicos de resistência são viáveis para a obtenção de biossensores}

O mecanismo natural de resistência a mercúrio, arsênio e chumbo em C. metallidurans foi a principal chave no desenho da estratégia deste projeto, onde buscou-se por empregar como fragmentos de DNA sensíveis aos íons mercúrio - merR/OP (Mergeay et al., 2003), arsênio - OP/arsR (Zhang et al., 2009) e chumbo - pbrR/OP (Borremans et al. 2001), sequências específicas do genoma C. metallidurans CH34. Foram escolhidas as regiões operadora/promotoras e os genes sensores respectivos, o que permitiu as fusões à montante da região estrutural do gene EGFP (Figura 27) do plasmídeo pBB-EGFP, possibilitando a contrução dos plasmídeos biossensores pGHg (Figura 10), pGAs (Figura 16) e pGPb (Figura 22).

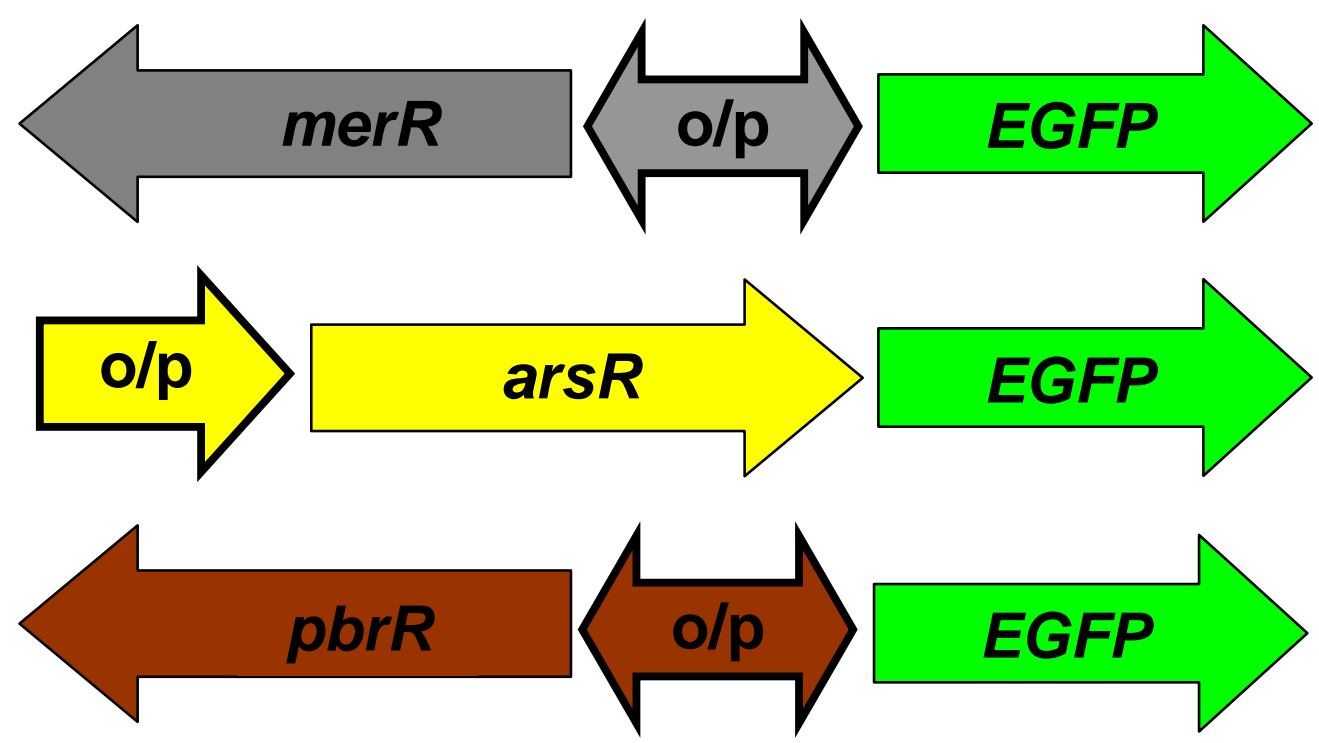

Figura 27 - Ilustração da técnica empregada onde as regiões operadora/promotoras e os genes sensores foram clonados à montante da região estrutural do gene EGFP. 
Vale ainda destacar que, de acordo a com nossas premissas, C. metallidurans CH34 possuindo mecanismo de regulação e resistência aos metais citados, quando hospedando os plasmídeos pGHg, pGAs e pGPb, mostrou grande capacidade biossensora na detecção e quantificação.

\subsection{Tempo de inoculação e leitura das amostras}

O parâmetro tempo de inoculação trouxe informações importantes. A deteção dos metais pôde ser percebida a partir de 2 horas de incubação. Uma vez que os biossensores ficaram expostos aos metais, a proteína EGFP teve uma produção contínua, sendo proporcional ao tempo exposição. Consequentemente, a quantificação da fluorescência após 24 horas de incubação mostrou altas taxas de IFR, o que possibilitou uma melhor determinação da faixa de quantificação dos metais. (Figuras 11, 12, 13, 14, 17, 18, 19, 20, 23, 24, 25 e 26). Nenhum dos autores citados na Tabela 2 (Magrisso, 2008) apresentou uma variação no tempo de inoculação.

\subsection{Viabilidade de inoculação dos biossensores bacterianos em água}

A inoculação dos biossensores em água também mostrou a possibilidade da empregabilidade diretamente na amostra e em suas diluições. Uma economia de tempo no preparo de meios e no gasto de insumos para análises quantitativas. Outro fator favorável para a incubação em água é que o chumbo encontrado em compostos químicos facilmente se precipita em meios de cultura, dificultando a absorção bacteriana (Magrisso, 2009; Maier et. al, 2000; Mergeay, 1985; Nies, 1999). Nenhum dos principais biossensores bacterianos apresentados na Tabela 2 (Magrisso, 2008) traz esta inovação.

\subsection{Aplicabilidade na quantificação dos biossensores frente aos valores de referência}

Os biossensores bacterianos contruídos neste trabalho trazem novas perspectivas de detecção e quantificação de mercúrio, arsênio e chumbo. A Tabela 6 compara os resultados obtidos com os valores máximos permitidos para substâncias químicas que representam risco à saúde, admitidos pelo Ministério da Saúde - Portaria $n^{\circ} 518$ (2004) e CONAMA Resolução $n^{0} 357$ (2005). Comparando com outros biossensores decritos na Tabela 2 
(Magrisso, 2008) e com estratégias de clonagem parecidas (gene sensor específico, gene repórter, bactéria hospedeira, faixa de leitura na quantificação e tempo de indução), poucos apresentaram resultados compatíveis com os valores de referência citados. A Tabela 7 (adaptação das Tabelas 2 e 6) compara os valores obtidos neste trabalho com valores de outros autores.

Os resultados somados dos clones biossensores E. coli e C. metallidurans / pGHg, acoplados à técnica analítica empregada, foram capazes de detectarem a presença de íons $\mathrm{Hg}^{2+}$ na faixa entre $80 \mu \mathrm{M}$ até $2,4 \mathrm{pM}$. Os clones $C$. metallidurans / pGAs e C. metallidurans / pGPb também obtiverem exelentes resultados, pois ambos foram capazes de detectar e quantificar valores dentro das referências de potabilidade, pertimindo assim suas aplicabilidades (Tabela 6).

Tabela 6 - Capacidade de quantificação dos biossensores bacterianos construíddos neste trabalho.

\begin{tabular}{|c|c|c|c|c|}
\hline Plasmídeo & $\begin{array}{c}\text { Bactéria } \\
\text { hospedeira }\end{array}$ & $\begin{array}{l}\text { Substrato de } \\
\text { Incubação }\end{array}$ & $\begin{array}{l}\text { Faixa de quantificação } \\
\text { (após 24h de incubação) }\end{array}$ & $\begin{array}{l}\text { Valor máximo } \\
\text { permitido* }\end{array}$ \\
\hline \multirow[t]{4}{*}{ pGHg } & C. metallidurans & $\mathrm{H}_{2} \mathrm{O}$ & Não se aplica & $4,985 \mu \mathrm{M}$ \\
\hline & & Caldo nutriente & 80 a $0,1563 \mu \mathrm{M}$ de $\mathrm{HgCl}_{2}$ & \\
\hline & E.coli & $\mathrm{H}_{2} \mathrm{O}$ & 625 a 0,0024 nM de $\mathrm{HgCl}_{2}$ & \\
\hline & & Caldo nutriente & 625 a 2,441 nM de $\mathrm{HgCl}_{2}$ & \\
\hline \multirow[t]{4}{*}{ pGAs } & C. metallidurans & $\mathrm{H}_{2} \mathrm{O}$ & Não se aplica & $0,1335 \mathrm{mM}$ \\
\hline & & Caldo nutriente & 200 a $0,0244 \mathrm{mM}$ de $\mathrm{Na}_{2} \mathrm{HAsO}_{4} \cdot 7 \mathrm{H}_{2} \mathrm{O}$ & \\
\hline & E. coli & $\mathrm{H}_{2} \mathrm{O}$ & Não se aplica & \\
\hline & & Caldo nutriente & Não se aplica & \\
\hline \multirow[t]{4}{*}{ pGPb } & C. metallidurans & $\mathrm{H}_{2} \mathrm{O}$ & 615 a $0,31 \mu M$ de $\mathrm{Pb}\left(\mathrm{NO}_{3}\right)_{2}$ & $48,3 \mu \mathrm{M}$ \\
\hline & & Caldo nutriente & Não se aplica & \\
\hline & E.coli & $\mathrm{H}_{2} \mathrm{O}$ & Não se aplica & \\
\hline & & Caldo nutriente & Não se aplica & \\
\hline
\end{tabular}

Fontes: * Ministério da Saúde - Portaria nº 518 (2004); CONAMA - Resolução nº 357 (2005) 
Tabela 7 - Comparação dos valores obtidos neste trabalho com valores de outros autores.

\begin{tabular}{|c|c|c|c|c|c|c|}
\hline $\begin{array}{l}\text { Gene } \\
\text { sensor }\end{array}$ & Metal & $\begin{array}{c}\text { Gene } \\
\text { Repórter }\end{array}$ & $\begin{array}{c}\text { Bactéria } \\
\text { hospedeira }\end{array}$ & $\begin{array}{c}\text { Faixa de } \\
\text { quantificação }\end{array}$ & $\begin{array}{l}\text { Tempo de } \\
\text { incubação }\end{array}$ & Referência \\
\hline \multirow{3}{*}{$\operatorname{mer} R$} & \multirow{3}{*}{$\mathrm{Hg}$} & GFP & E. coli & 500 a $5 \mu \mathrm{M}$ & $8 \mathrm{~h}$ & Hakkila et al. (2002) \\
\hline & & EGFP & E. coli & 625 a $0,0024 \mathrm{nM}$ & $24 \mathrm{~h}$ & Este trabalho \\
\hline & & EGFP & C. metallidurans & 80 a $0,1563 \mu \mathrm{M}$ & $24 \mathrm{~h}$ & Este trabalho \\
\hline \multirow{3}{*}{$\operatorname{ars} R$} & \multirow{3}{*}{ As } & GFP & E. coli & 25 a $0,4 \mathrm{mM}$ & $120 \min$ & Liao e Ou (2005) \\
\hline & & & E. coli & 133 a $0,13 \mathrm{mM}$ & $12 \mathrm{~h}$ & Roberto et al. (2002) \\
\hline & & EGFP & C. metallidurans & 200 a $0,0244 \mathrm{mM}$ & $24 \mathrm{~h}$ & Este trabalho \\
\hline \multirow{2}{*}{ pbrR } & \multirow{2}{*}{$\mathrm{Pb}$} & GFP & E. coli & 400 a $50 \mu \mathrm{M}$ & $12 \mathrm{~h}$ & Chakraborty et al. (2008) \\
\hline & & EGFP & C. metallidurans & 615 a $0,31 \mu \mathrm{M}$ & $24 \mathrm{~h}$ & Este trabalho \\
\hline
\end{tabular}

\subsection{Considerações finais}

Tomados em conjunto, os dados obtidos indicam que os objetivos deste trabalho foram atingidos, onde através de técnicas de engenharia genética, três biossensores bacterianos, cada um deles especificamente capaz de detectar e quantificar os metais pesados mercúrio, arsênio e chumbo.

Os plasmídeos pGHg, pGAs e pGPb (uma vez que estes plasmídeos possuem um amplo-espectro para transformação de bactérias Gram-negativas; gene de resistência ao cloranfenicol; possibilidade de transformação por conjugação) caso sejam introduzidos noutras bactérias Gram-negativas, cujo o patrimônio genético garante-lhe maior resistência aos íons metálicos, potencialmente haverá a possibilidade de construção de novas bactérias recombinantes com capacidade de detecção e quantificação dentro de uma faixa mais ampla de concentração. 
6 CONCLUSÕES 


\subsection{Biossensor de Mercúrio}

- O fragmento de DNA correspondente aos genes merR/OP de C. metallidurans CH34 foi amplificado, com sucesso, empregando-se a técnica de PCR, utilizando oligonucleotídios desenhados neste trabalho. Este fragmento de DNA foi clonado, com sucesso, no vetor pTZ57R/T, obtendo o plasmídeo pTZ-Mer;

- O fragmento de DNA sensível a presença de íons $\mathrm{Hg}^{2+}$ (merR/OP) foi inserido à montante do gene EGFP no vetor caça promotor pBB-EGFP, originando o plasmídeo biossensor pGHg.

- Os Clones E. coli DH5a / pGHg e C. metallidurans CH34 / pGHg expressam a proteína EGFP na presença de íons $\mathrm{Hg}^{2+}$, demonstrando a funcionalidade do biossensor de mercúrio construído;

- Os resultados somados dos clones biossensores E.coli e C. metallidurans / pGHg, acoplados à técnica analítica empregada, foram capazes de detectarem a presença de íons $\mathrm{Hg}^{2+}$ na faixa entre $80 \mu \mathrm{M}$ até $1,2 \mathrm{pM}$.

\subsection{Biossensor de Arsênio}

- $\quad$ O fragmento de DNA correspondente aos genes OP/arsR de C. metallidurans CH34 foi amplificado, com sucesso, empregando-se a técnica de PCR, utilizando oligonucleotídios desenhados neste trabalho. Este fragmento de DNA foi clonado, com sucesso, no vetor pTZ57R/T, obtendo o plasmídeo pTZ-Ars;

- O fragmento de DNA sensível a presença de íons $\mathrm{As}^{2+}(\mathrm{OP} / \mathrm{arsR})$ foi inserido a montante do gene EGFP no vetor caça promotor pBB-EGFP, originando o plasmídeo biossensor pGAs.

- Os Clones E. coli DH5a / pGAs e C. metallidurans CH34 / pGAs expressam a proteína EGFP na presença de íons $\mathrm{As}^{3+}$, demonstrando a funcionalidade do biossensor de arsênio construído; 
- O clone recombinante C. metallidurans CH34 / pGAs apresentou melhores resultados de IFR como biossensor de arsênio do que a linhagem recombinate E. coli DH5a / pGAs;

\subsection{Biossensor de Chumbo}

- O fragmento de DNA correspondente aos genes pbrR/OP de C. metallidurans CH34 foi amplificado, com sucesso, empregando-se a técnica de PCR, utilizando oligonucleotídios desenhados neste trabalho. Este fragmento de DNA foi clonado, com sucesso, no vetor pTZ57R/T, obtendo o plasmídeo pTZ-Pbr;

- O fragmento de DNA sensível a presença de íons $\mathrm{Pb}^{2+}$ ( $\left.p b R / \mathrm{OP}\right)$ foi inserido a montante do gene EGFP no vetor caça promotor pBB-EGFP, originando o plasmídeo biossensor pGPb.

- Não houve uma de detecção significativa de íons $\mathrm{Pb}^{2+}$ pelo clone recombinate $E$. coli $\mathrm{DH} 5 \alpha / \mathrm{pGPb}$,

- O clone recombinante C. metallidurans CH34 / pGPb expressa a proteína EGFP na presença de íons $\mathrm{Pb}^{2+}$, demonstrando a funcionalidade do biossensor de chumbo construído; 


\section{REFERÊNCIAS*}

Alfaya AAS, Kubota LT. A utilização de materiais obtidos pelo processo de sol-gel na construção de biossensores. Quim Nova. 2002;25(5):835-41.

Barra CM, Santelli RE, Abrão JJ, de la Guardia M. Especiação de arsênio - uma revisão Quim Nova. 2000:23-58.

Ben-Israel O, Ben-Israel $\mathrm{H}$, Ulizur S. Identification and quantification of toxic chemicals by use of Escherichia coli carrying lux genes fused to stress promoters. Appl Environ Microbiol. 1998;64:4346-52.

Bhatia RB, Brinker CJ, Gupta AK, Singh AK. Aqueous sol-gel process for protein encapsulation. Chem Mater. 2000;12:2434-41.

Biondo R. Engenharia Genética de Cupriavidus metallidurans para biorremediação de efluentes contendo metais pesados. [tese (Doutorado em Biotecnologia)]. São Paulo (Brasil): Instituto de Ciências Biomédicas da Universidade de São Paulo; 2008.

Biran I, Babai R, Levcov K, Rishpon J, Ron EZ. Online and in situ monitoring of environmental pollutants: electrochemical biosensing of cadmium. Environ Microbiol. 2000;2(3):285-90.

Bontidean I, Lloyd JR, Hobman JL, Wilson JR, Csoregi E, Mattiasson B, Brown NL. Bacterial metal-resistance proteins and their use in biosensors for the detection of bioavailable heavy metals. J Inorg Biochem. 2000;79:225-9.

Bontidean I, Mortari A, Leth S, Brown NL, Karlson U, Larsen MM, et al. Biosensors for detection of mercury in contaminated soils. Environ Pollut. 2004;131:255-62.

Borremans B, Hobman JL, Provoost A, Brown NL, Van der Lelie D. Cloning and functional analysis of the pbr lead resistance determinant of Ralstonia metallidurans CH34. Journal of Bacteriology. 2001;183:5651-8.

Boyanapalli R, Bullerjahn GS, Pohl C, Croot PL, Boyd PW, McKay R, Michael L. Luminescent whole-cell cyanobacterial bioreporter for measuring Fe availability in diverse marine environments. Appl Environ Microbiol. 2007;73:1019-24.

Brasil. Ministério da Saúde. Norma de qualidade da água para consumo humano. Portaria n. ${ }^{\circ}$ 518, de 25 de março de 2004, [homepage on the Internet]. Disponível em: http://portal.saude.gov.br/portal/arquivos/pdf/portaria_518_2004.pdf [2011 set. 12].

Brunis MR, Kapil S, Oehme WF. Microbial resistance to metals in the environment. Ecotoxicol Environ Saf. 2000;45:198-207. 
Cai J, Dubow SM. Use of a luminescent bacterial biosensor for biomonitoring and characterization of arsenic toxicity of chromated copper arsenate (CCA). Biodegradation. 1997;8:105-11.

Carlin A, Shi W, Dey S, Rosen B. The ars operon of Escherichia coli confers arsenical and antimonial resistance. J Bacteriol. 1995;177(4):981-6.

Companhia Ambiental do Estado de São Paulo, CETESB. Informações toxicológicas. 2010 [homepage on the Internet]. Disponível em: http://www.cetesb.sp.gov.br/tecnologiaambiental/laboratorios/109-informacoes-toxicologicas[2011 set. 12].

Chakraborty T, Babu PG, Alam A, Chaudhari A. GFP expressing bacterial biosensor to measure lead contamination in aquatic environment. Curr Sci.2008;94(6):800-5.

Champier L, Duarte V, Michaud-Soret I, Coves J. Characterization of the MerD protein from Ralstonia metallidurans CH34: a possible role in bacterial mercury resistance by switching off the induction of the mer operon. Mol Microbiol. 2004;52(5):1475-85.

Chang JC, Taylor PB, Leach FR. Use of the Microtox assay system for environmental samples. Bull Environ Contam Toxicol. 1981;26(2):150-6.

Chatterjee J, Meighen EA. Biotechnical applications of bacterial bioluminescence (lux) genes. Photochem Photobiol. 1995;62:641-50.

Clontech. Living Colors Enhanced GFP Vectors: The brightest GFP chromophore variant for maximal sensitivity in mammalian cells. CLONTECHniques; 1996.

Conselho Nacional do Meio Ambiente (CONAMA). Resolução $n^{0}$ 357, de 17 de março de 2005 [homepage on the Internet]. Disponível em: http://www.mma.gov.br/port/conama/res/res05/res35705.pdf [2011 set. 12].

Corbisier P, van der Lelie D, Borremans B, Provoost A, Lorenzo V, Brown NL, et al.. Whole cell and protein-based biosensors for the detection of bioavailable heavy metals in environmental samples. Anal Chim Acta. 1999;387:235-44.

Central Única dos Trabalhadores (CUT). Meio ambiente, saúde e trabalho: O movimento sindical pode ajudar a melhorar o ambiente. Comissão de Meio Ambiente.Rio de Janeiro, 2000 [homepage on the Internet]. Disponível em: http://www.sindipetro.org.br/extra/cartilhacut/10metaispesados.htm [2011 set. 12].

de Lorenzo V, Kuenen G. Scientific basis for the bioremediation of the toxic spill of the Aznalcollar mine: combining bacteria and plants to address and intractable kind of pollution. Environ Microbiol. 1999;1(3):275-8.

Diels L, Lelie N. van der, Bastiaens L. New developments in treatment of heavy metal contaminated soils. Rev Environ Sci Bio/Technol. 2002;1:75-82

Diorio C, Cai J, Marmor J, Shinder R, DuBow MS. An Escherichia coli chromosomal ars operon homolog is functional in arsenic detoxification and is conserved in gram-negative bacteria. J Bacteriol. 1995;177:2050-6. 
D'Souza SF. Microbial biosensors. Biosens Bioelectron. 2001;16(6):337-53.

DuBow MS. The detection and characterization of genetically programmed responses to environmental stress. Ann N Y Acad Sci. 1998;851:286-91.

Errampalli D, Leung K, Cassidy MB, Kostrzynska M, Blears M, Lee H, Trevors JT. Applications of the green fluorescent protein as a molecular marker in environmental microorganisms. J Microbiol Methods. 1999;35(3):187-99.

Figueiredo AMG, Enzwiler J, Camargo IMC, Sigolo JB, Gumiero FC, Pavese A, Millian FM. Metal contaminantion in urban park soils of São Paulo. J Radioanal Nucl Chem. 2009;280(2):423-9.

Golding GR, Kelly CA, Sparling R, Loewen PC, Rudd WMJ, Barkay T. Evidence for facilitated uptake of $\mathrm{Hg}(\mathrm{II})$ by Vibrio anguillarum and Escherichia coli under anaerobic and aerobic conditions. Limnol Oceanogr. 2002;47:967-75.

Goyer RA. Toxic and essential metal interactions, Annu. Rev. Nutr. 1997;17:37-50

Grass G, Fricke B, Nies DH. Control of expression of a periplasmic nickel efflux pump by periplasmic nickel concentrations. Biometals. 2005;18(4):437-48.

Guzzo J, Guzzo A, DuBow MS. Characterization of the effects of aluminum on luciferase biosensors for the detection of ecotoxicity. Toxicol Lett. 1992:687-93.

Hakkila K, Green T, Leskinen P, Ivask A, Marks R, Virta M. Detection of bioavailable heavy metals in EILATox-Oregon samples using whole-cell luminescent bacterial sensors in suspension or immobilized onto fibre-optic tips. J Appl Toxicol. 2004;24(5):333-42.

Hakkila K, Maksimow M, Karp M, Virta M. Reporter genes lucFF, luxCDABE, gfp, and dsred have different characteristics in whole-cell bacterial sensors. Anal Biochem. 2002;301(2):235-42.

Huckle JW, Morby AP, Turner JS, Robinson NJ. Isolation of a prokaryotic metallothionein locus and analysis of transcriptional control by trace metal ions. Mol Microbiol. 1993;7:17787.

International Chemical Safety Cards (ICSCs). World Health Organization (WHO) [homepage on the Internet]. Geneva, Switzerland. Disponível em: http://www.ilo.org/legacy/english/protection/safework/cis/products/icsc/dtasht/index.htm [2011 Sept. 12].

Ivask A, Virta M, Kahru A. Construction and use of specific luminescent recombinant bacterial sensors for the assessment of bioavailable fraction of cadmium, zinc, mercury and chromium in the soil. Soil Biol Biochem. 2002;34:1439-47.

Ivsak A, Hakkila K, Virta M. Detection of organomercurials with sensor bacteria. Anal Chem. 2001;73:5168-71. 
Iwuoha EI, Kane S, Ania CO, Smyth MR, de Montellano PRO, Fuhr U. Reactivities of organic phase biosensors 3: electrochemical study of cytochrome P450. Electranalysis. 2000;12:980-6.

Ji G, Silver S. Regulation and expression of the arsenic resistance operon from Staphylococcus aureus plasmid pI258. J Bacteriol. 1992;174:3684-94.

Joyner CD, Steven EL. Heterogeneity of iron bioavailability on plants assessed with a wholecell GFP based bacterial biosensor. Microbiology. 2000;146:2435-45.

Lee SM, Suzuki M, Kumagai M, Ikeda H, Tamiya E, Karube I. Bioluminescence detection system of mutagen using firefly luciferase genes introduced in Escherichia coli lysogenic strain. Anal Chem. 1992;64(17):1755-9.

Lee SM, Suzuki M, Tamiya E, Karube I. Microbial detection of toxic compounds utilizing recombinant DNA technology and bioluminescence. Anal Chim Acta. 1991;244(2):201-6.

Li X, Zhang G, Ngo N, Zhao X, Kain SR, Huang CC. Deletions of the Aequorea victoria green fluorescent protein define the minimal domain required for fluorescence. J Biol Chem. 1997;272(45):28545-9.

Liu X, Germaine KJ, Ryan D, Dowling DN. Whole-Cell fluorescent biosensors for bioavailability and biodegradation of polychlorinated biphenyls. Sensors. 2010;10(2):13771398.

Liao VHC, Ou KL. Development and testing of a green fluorescent protein-based bacterial biosensor for measuring bioavailable arsenic in contaminated groundwater samples. Environ Toxicol Chem. 2005;24:1627-31.

Liao VHC, Chien MT, Tseng YY, Ou KL. Assessment of heavy metal bioavailability in contaminated sediments and soils using green fluorescent protein-based bacterial biosensors. Environ Pollut. 2006;142:17-23.

Magrisso S, Erel Y, Belkin S. Microbial reporters of metal bioavailability. Microbial Biotech. 2008;1:320-30

Magrisso S, Belkin S, Erel Y. Lead bioavailability in soil and soil components. Water Air Soil Poll. 2009; 202(1-4):315-323.

Maier RM, Pepper IL, Gerba C. Environmental Microbiology. San Diego: Academic Press, 2000.

Mergeay M, Monchy S, Vallaeys T, Auquier V, Benotmane A, Bertin P, Taghavi S, Dunn J, van der Lelie D, Wattiez R. Ralstonia metallidurans, a bacterium specifically adapted to toxic metals: towards a catalogue of metal-responsive genes. Microbiol Rev. 2003;27(2-3):385-410.

Monchy S, Vallaeys T, Bossus A, Mergeay M. Metal transport ATPase genes from Cupriavidus metallidurans CH34: a transcriptomic approach. Int J Environ Anal Chem. 2006;86(9):677-92. 
Mulchandani A, Bassi AS. Principles and applications of biosensors for bioprocess monitoring and control. Crit Rev Biotechnol. 1995;15:105-24.

Muniz DHF, Oliveira-Filho EC. Metais pesados provenientes de rejeitos de mineração e seus efeitos sobre a saúde e o meio ambiente. Universitas: Ciências da Saúde. 2006:4:83-100

Nascimento AMA, Azevedo MO, Astolfi-Filho S, Chartone-Souza E. Cloning of the mercury ion resistance operon of pBH100 Escherichia coli 5K using pAT153 as vector. Revista de Microbiologia. 1992;23:217-20

Nascimento AMA, Chartone-Souza E. Operon mer: bacterial resistance to mercury and potential for bioremediation of contaminated environments. Genet Mol Res. 2003;2(1):92101.

Nies DH. Microbial heavy-metal resistance. Applied Microbiology and Biotechnology. 1999;51(6):730-50.

Omura T, Kiyono M, Pan-Hou H. Development of a specific and sensitive bacteria sensor for detection of mercury at picomolar levels in environment. J Health Sci. 2004;50(4):379-83.

Peitzsch N, Eberz G, Nies HD. Alcaligenes eutrophus as a bacterial chromate sensor. Appl Environ Microbiol. 1998;64:453-8.

Pepi M, Reniero D, Baldi B, Barbieri P. A comparison of mer::lux whole cell biosensors and moss, a bioindicator for estimating mercury pollut. Water Air Soil Pollut. 2006;173:163-75.

Petanen T, Romantschuk M. Toxicity and bioavailability to bacteria of particle-associated arsenite and mercury. Chemosphere. 2003;50:409-13

Petanen T, Virta M, Karp M, Romantschuk M. Construction and use of broad host range mercury and arsenite sensor plasmid in the soil bacterium P. fluorescens OS8. Microbiol Ecol. 2001;41:360-8.

Piveli R, Kato MT. Qualidade das águas e poluição: aspectos físicos-químicos. ABES. 2005:173-87.

Prasher DC, Eckenrode VK, Ward WW, Prendergast FG, Cormier MJ. Primary structure of the Aequorea victoria green-fluorescent protein. Gene. 1992;111(2):229-33.

Quadros OF. Construção de biossensor bacteriano para detecção de mercúrio [dissertação (Mestrado em Biotecnologia)]. São Paulo (Brasil): Instituto de Ciências Biomédicas da Universidade de São Paulo; 2007.

Ramanathan S, Ensor $\mathrm{M}$ and Daunert. Bacterial biosensors for monitoring toxic metals. TIBTECH. 1997;15:500-6.

Ramanathan S, Shi W, Rosen BP, Daunert S. Bacteria-based chemiluminescence sensing system using [beta]-galactosidase under the control of the ArsR regulatory protein of the ars operon. Anal Chim Acta. 1998;369:189-95. 
Riether KB, Dollard MA, Billard P. Assessment of heavy metal bioavailability using Escherichia coli zntAp::lux and copAp::lux-based biosensors. Appl Microbiol Biotechnol. 2001;57:712-6.

Roane TM, Pepper IL. Microbial responses to environmentally toxic cadmium. Microbiol. Ecol. 2000;38:358-64

Roberto F, Barnes FMJ, Bruhn FD. Evaluation of a gfp reporter gene construct for environmental arsenic detection. Talanta. 2002;58:181-8.

Rosen BP, Bhattacharjee H, Zhou T, Walmsley AR. Mechanism of the ArsA ATPase. Biochim Biophys Acta. 1999;1461:207-15.

Rossy E, Seneque O, Lascoux D, Lemaire D, Crouzy S, Delangle P, Coves J. Is the cytoplasmic loop of MerT, the mercuric ion transport protein, involved in mercury transfer to the mercuric reductase? FEBS Lett. 2004;575(1-3):86-90.

Sambrook J, Russell DW. Molecular Cloning: A Laboratory Manual. 3rd ed. New York: Cold Spring Harbor Press; 2001. 3 vol.

Scott DL, Ramanathan S, Shi W, Rosen BP, Daunert S. Genetically engineered bacteria: electrochemical sensing systems for antimonite and arsenite. Anal Chem. 1997;69:16-20.

Selifonova O, Burlage R, Barkay T. Bioluminescent sensors for detection of bioavailable mercury (II) in the environment. Appl Environ Microbiol. 1993;59:3083-90.

Shetty RS, Deo SK, Shah P, Sun Y, Rosen BP, Daunert S. Luminescence-based wholecellsensing systems for cadmium and lead using genetically engineered bacteria. Anal Bioanal Chem. 2003;376:11-7.

Shetty RS, Deo KS, Liu Y, Daunert S. Fluorescence-based sensing system for copper using genetically engineered living yeast cells. Biotechnol Bioeng. 2002;88:664-70.

Silver S, Phung LT. A bacterial view of the periodic table: genes and proteins for toxic inorganic ions. J Ind Microbiol Biotechnol. 2005;12:1-19.

Sofia H, Burland V, Daniels D, Plunkett Gr, Blattner F. Analysis of the Escherichia coli genome. V. DNA sequence of the region from 76.0 to 81.5 minutes. Nucleic Acids Res. 1994;22(13):2576-86.

Stocker J, Balluch D, Gsell M, Harms H, Feliciano J, Daunert S., et al. Development of a set of simple bacterial biosensors for quantitative and rapid measurements of arsenite and arsenate in potable water. Environ Sci Technol. 2003;37:4743-50.

Taghavi S, Mergeay M, Nies D, van der Lelie D. Alcaligenes eutrophus as a model system for bacterial interactions with heavy metals in the environment. Res Microbiol. 1997;148(6):53651.

Tauriainen S, Karp M, Chang W, Virta M. Luminescent bacterial sensor for cadmium and lead. Biosens Bioelectron. 1998;13(9):931-8. 
Tauriainen S, Karp M, Chang W, Virta M. Recombinant luminescent bacteria for measuring bioavailable arsenite and antimonite. Appl Environ Microbiol. 1997;63:4456-61.

Tauriainen S, Virta M, Chang W, Lampinen J, Karp M. Measurement of firefly luciferase reporter gene activity from cells and lysates using Escherichia coli arsenite and mercury sensors. Anal Biochem; 1999;272:191-8.

Tecon R, van der Meer JR. Information from single-cell bacterial biosensors: what is it good for? Curr Opin Biotechnol. 2006;17(1):4-10.

Tibazarwa C, Corbisier P, Mench M, Bossus A, Solda P, Mergeay M, et al. A microbial biosensor to predict bioavailable nickel in soil and its transfer to plants. Environ Pollut. 2001;113:19-26.

Tom-Petersen A, Hosbond C, Nybroe O. Identification of copper-induced genes in Pseudomonas fluorescens and use of a reporter strain to monitor bioavailable copper in soil. FEMS Microbiol Ecol. 2001;38:59-67.

Trang PTK, Berg M, Viet PH, Mui NV, Van der Meer JR. Bacterial bioassay for rapid and accurate analysis of arsenic in highly variable groundwater samples. Environ Sci Technol. 2005;39:7625-30.

Tsien RY. The green fluorescent protein. Annu Rev Biochem. 1998;67:509-44.

Turner APF, Karube Y, Wilson GS. Biosensors. Fundamentals and Applications. New York: Oxford University Press; 1987.

Vandamme P, Coenye T. Taxonomy of the genus Cupriavidus: a tale of lost and found. Int $\mathrm{J}$ Syst Evol Microbiol. 2004;54:2285-9.

Vieira JLF, Passarelli MM. Determinação de mercúrio total em amostras de água, sedimento e sólidos em suspensão de corpos aquáticos por espectrofotometria de absorção atômica com gerador de vapor a frio. Rev Saúde Pública, 1996;30:256-60.

Virta M, Lampinen J, Karp M. A luminescence-based mercury biosensor. Anal Chem. 1995;67:667-9.

Ward WW, Cody CW, Hart RC. Spectrophotometric identity of the energy transfer chromophores in Renilla and Aequorea green fluorescent proteins. Photochem Photobiol Rev. 1980;31:611-5.

Weitz HJ, Ritchie JM, Bailey DA, Horsburgh AM, Killham K, Glover LA. Construction of a modified mini-Tn5 luxCDABE transposon for the development of bacterial biosensors for ecotoxicity testing. Microbiol Lett. 2001;197(2):159-65.

Wells M, Gosch M, Rigler R, Harms H, Lasser T, van der Meer JR. Ultrasensitive reporter protein detection in genetically engineered bacteria. Anal Chem. 2005;77(9):2683-9. 
Welsh S, Kay SA. Reporter gene expression for monitoring gene transfer. Current Biology in Biotechnology. 1997;8:617-22.

Xu C, Shi W, Rosen B. The chromosomal arsR gene of Escherichia coli encodes a transacting metalloregulatory protein. J Biol Chem. 1996;271(5):2427-32.

Yagi K. Applications of whole-cell bacterial sensors in biotechnology and environmental science. Applied Microbiology and Biotechnology. 2007;73(6):1251-8.

Yoon KP, Misra TK, Silver S. Regulation of the cadA cadmium resistance determinant of Staphylococcus aureus plasmid pI258. J Bacteriol. 1991;173:7643-9.

Zhang Y, Monchy S, Greenberg B, Mergeay M, Gang O, Taghavi S, et al. ArsR arsenicresistance regulatory protein from Cupriavidus metallidurans CH34. Antonie Van Leeuwenhoek. 2009;96(2):161-70.

Zhang YZ, Naleway JJ, Larison KD, Huang ZJ, Haugland RP. Detecting lacZ gene expression in living cells with new lipophilic, fluorogenic $\beta$-galactosidase substrates. FASEB J. 1991;5(15):3108-13. 